University of Nebraska - Lincoln

DigitalCommons@University of Nebraska - Lincoln

Papers in the Earth and Atmospheric Sciences

Earth and Atmospheric Sciences, Department

\title{
Upper Cretaceous diatom biostratigraphy of the Arctic archipelago and northern continental margin, Canada
}

Pedro M. Tapia

University of Nebraska-Lincoln

David M. Harwood

University of Nebraska-Lincoln, dharwood1@unl.edu

Follow this and additional works at: https://digitalcommons.unl.edu/geosciencefacpub

Part of the Earth Sciences Commons

Tapia, Pedro M. and Harwood, David M., "Upper Cretaceous diatom biostratigraphy of the Arctic archipelago and northern continental margin, Canada" (2002). Papers in the Earth and Atmospheric Sciences. 184.

https://digitalcommons.unl.edu/geosciencefacpub/184

This Article is brought to you for free and open access by the Earth and Atmospheric Sciences, Department of at DigitalCommons@University of Nebraska - Lincoln. It has been accepted for inclusion in Papers in the Earth and Atmospheric Sciences by an authorized administrator of DigitalCommons@University of Nebraska - Lincoln. 


\title{
Upper Cretaceous diatom biostratigraphy of the Arctic archipelago and northern continental margin, Canada
}

\author{
Pedro M. Tapia and David M. Harwood \\ Department of Geosciences, University of Nebraska-Lincoln, Lincoln, NE 68588-0340, USA \\ email: ptapia@unlserve.unl.edu
}

\begin{abstract}
Strata in the Canadian Arctic contain diverse and moderately well-preserved Late Cretaceous siliceous microfossil assemblages. One-hundred-twelve samples were analyzed from a composite stratigraphic section (1094m-thick) of the Smoking Hills, Mason River and Kanguk formations. Four sections were examined: (1) Slidre Fjord on Ellesmere Island; (2) Hoodoo Dome on Ellef Ringnes Island; (3) Cape Nares on Eglinton Island; and (4) Horton River on the Anderson Plains, Northwest Territories. Two hundred-three diatom taxa were identified in forty-nine productive samples. Four Upper Cretaceous diatom zones are proposed for the Canadian Arctic based on the biostratigraphic distribution of diatoms: (i) the Upper Cenomanian to Upper Santonian(?) Gladius antiquus Concurrent Range Zone, (ii) the Lower Campanian Costopyxis antiqua Partial Range Zone, (iii) the lower Upper Campanian Trinacria indefinita Interval Zone, and (iv) the upper Upper Campanian Stephanopyxis simonseni Partial Range Zone.

The diatom assemblages are similar to those of Alpha Ridge (Arctic Ocean), Ural Mountains (Russia), and Campbell Plateau (SW Pacific Ocean), enabling diatom-based biostratigraphical correlations within the northern high-latitudes and to the southern high-latitudes. A fifth biostratigraphic zone, Azpeitiopsis morenoensis Concurrent Range Zone, is also proposed, based on common and widespread distribution of the nominative taxon in lower to upper Maastrichtian sediments. Sufficient data is now available to establish the construction of a diatom-based standard zonal framework for the Upper Cretaceous.

Two new combinations, Trochosira denticulatum (Strelnikova) Tapia and Trochosiropsis polychaeta (Strelnikova) Tapia are here proposed.
\end{abstract}

\section{INTRODUCTION}

\section{Diatoms in time and space}

Diatoms are known from the Lower Cretaceous (AptianAlbian) to Recent and represent useful tools as biostratigraphic, paleoenvironmental, and paleoclimatic indicators (Stoermer and Smol 1999). The Cenozoic diatom biostratigraphic record is relatively well-developed (Barron and Baldauf 1995), though many stratigraphic gaps still exist in the Paleocene and Eocene diatom record around the world. Upper Cretaceous diatom biostratigraphy, however, requires considerable further development through collection of stratigraphic data, taxonomic reorganization, morphological description, and biostratigraphical analysis such as that presented here. A compilation of known Upper Cretaceous diatom-bearing sediments (table 1, text-fig. 1) expresses the limitation of our current knowledge for this stratigraphic interval. Diatom preservation is the limiting factor on many of these deposits.

This paper is an attempt to develop an Upper Cretaceous diatom biostratigraphy for the Canadian Arctic. Our main goal is to identify the main diatom assemblages in order to apply diatom biostratigraphy to the stratigraphic sequences of the Kanguk, Smoking Hills, and Mason River formations. The moderately good preservation of diatoms from these strata enables us to investigate changes in diversity and composition of siliceous microfossil assemblages from the northern high-latitudes (text-fig. 2). Thick stratigraphic sections, like the $125 \mathrm{~m}$-thick continuous and moderately well-preserved diatomaceous shale of the Horton River section represent an excellent reference section for development of a biostratigraphic framework for future correlation.
Status of Late Cretaceous diatoms: taxonomic studies vs the stratigraphic record

Our knowledge of Late Cretaceous diatoms is hindered by the temporal instability of opal-A and detrimental effects of silica diagenesis through time. Most published Late Cretaceous diatom studies are descriptive and taxonomic, with little or no stratigraphic control (table 1). Nevertheless, general trends in Upper Cretaceous diatom biostratigraphy and evolution can be found in Strelnikova (1974) and Harwood and Nikolaev (1995). Current knowlegde of Campanian diatom biostratigraphy was developed from high-latitude diatomaceous deposits in Russia and the S.W. Pacific Ocean. These deposits contain sufficiently well-preserved diatom floras and reliable stratigraphic control that can be compared to results presented here.

Outcrops and industrial wells from the Ural Mountains and Western Siberian lowland plains, Russia. The best sequence that contains Upper Cretaceous opaline diatoms is in north-central Russia. A 299m-thick composite core section along the North Sosva River (Cores 22, 82, and 19; text-fig. 3-A) and outcrop samples from the Syinja River [Sections XI(14) and IX(13)] record portions of the Campanian and Maastrichtian (Strelnikova 1974, 1975). Strelnikova divided the Campanian sequence into three diatom complexes. The First Complex (aleuritic diatomaceous clays, Lower Campanian) is characterized by diatoms Paralia cretacea, P. ornata, Costopyxis antiqua, C. uralensis, Lepidodiscus elegans, Triceratium schulzii, Hemiaulus danicus, H. echinulatus, Pterotheca alata, and P. simplex. The Prunobrachium crassum radiolarian complex and the foraminiferal Spiroplectammina lata Zone provide biostratigraphic control that indicates an Early Campanian age. The Second Complex (white diatomite, lower part of the Upper Campanian) 
TABLE 1

Occurences of Upper Cretaceous bearing-diatom deposits in the world.

\begin{tabular}{|c|c|c|c|c|}
\hline Age & Reference & Location & Preservation & Remarks \\
\hline $\begin{array}{l}\text { Albian to Early } \\
\text { Cenomanian }\end{array}$ & $\begin{array}{l}\text { Foulcault et al., } \\
(1986)\end{array}$ & $\begin{array}{l}\text { Ligurian Alps, } \\
\text { Italy }\end{array}$ & Poor & $\begin{array}{c}\text { Resembles } \\
\text { younger diatom } \\
\text { assemblages }\end{array}$ \\
\hline Turonian & Müller (1912) & $\begin{array}{l}\text { Rielmerich, } \\
\text { Westfalia, } \\
\text { Germany }\end{array}$ & Poor & 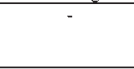 \\
\hline Turonian & Weisner (1936) & $\begin{array}{c}\text { Bohême, } \\
\text { Czechoslovakia }\end{array}$ & Poor & - \\
\hline Turonian & $\begin{array}{c}\text { Deflandre } \\
(1241)\end{array}$ & $\begin{array}{c}\text { Villers-Sur-Mer, } \\
\text { Calvados }\end{array}$ & Poor & $\begin{array}{c}\text { Taxonomic } \\
\text { approach }\end{array}$ \\
\hline $\begin{array}{l}\text { Early Turonian } \\
\text { to Late } \\
\text { Campanian }\end{array}$ & $\begin{array}{c}\text { Kouttsoukos and } \\
\text { Hlart (1990) }\end{array}$ & $\begin{array}{c}\begin{array}{c}\text { Sergipe Basin, } \\
\text { Brazil }\end{array} \\
\end{array}$ & Poor & $\begin{array}{c}\text { Aracaju Member } \\
\text { Cotiguiba } \\
\text { Formation }\end{array}$ \\
\hline $\begin{array}{l}\text { Coniacian and } \\
\text { Santonian }\end{array}$ & $=$ & - & - & No reports \\
\hline Senonian & Schulz (1935) & \begin{tabular}{|l|} 
Gdansk, Poland \\
\end{tabular} & Good & Campanian. \\
\hline Campanian & \begin{tabular}{|c|} 
Kitchel' (1980), \\
Barron (1985), \\
Dell' Agnese \\
(1988), \\
Dell'Agnese and \\
Clark (1994) \\
\end{tabular} & $\begin{array}{l}\text { Alpha Ridge, } \\
\text { Arctic Ocean }\end{array}$ & Excellent & $\begin{array}{c}\text { Microfossil } \\
\text { documentation, } \\
\text { biostratigraphic } \\
\text { approach }\end{array}$ \\
\hline Campanian & Riegraf (1995) & $\begin{array}{l}\text { Westfalia, NW } \\
\text { Germany }\end{array}$ & Poor & - \\
\hline Campanian & $\begin{array}{c}\text { Moshkovitz et } \\
\text { al., (1983) }\end{array}$ & $\begin{array}{l}\text { Central Negev, } \\
\text { Israel }\end{array}$ & Moderate & $\begin{array}{c}\text { Mishah } \\
\text { Formation }\end{array}$ \\
\hline Campanian & $\begin{array}{c}\text { Gresham (1985 } \\
1986)\end{array}$ & $\begin{array}{c}\text { DSDP Leg 22, } \\
\text { Site } 216\end{array}$ & Moderate & $\begin{array}{c}\text { Ninetyeast } \\
\text { Ridge, Indian } \\
\text { Ocean }\end{array}$ \\
\hline Campanian & $\begin{array}{c}\text { Fourtanier } \\
\text { (1991) }\end{array}$ & $\begin{array}{l}\text { ODP Leg } 121, \\
\text { Site } 758\end{array}$ & Moderate & 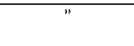 \\
\hline Campanian & $\begin{array}{c}\text { Baliance et al.. } \\
\text { (1989) }\end{array}$ & Tonga Trench & Moderate & Pacific Ocean \\
\hline Campanian & $\begin{array}{c}\text { Hajos and } \\
\text { Stradner (1975) }\end{array}$ & $\begin{array}{c}\text { DSDP Lcy } 29, \\
\text { Site } 275\end{array}$ & Excellent & $\begin{array}{c}\text { Biostratigraphy, } \\
\text { SW Pacific }\end{array}$ \\
\hline Campanian & $\begin{array}{c}\text { Given and Wall } \\
\text { (1971); Wall } \\
\text { (1975) }\end{array}$ & Alberta, Canada & Pytitized & - \\
\hline $\begin{array}{l}\text { Campanian to } \\
\text { Maastrichtian }\end{array}$ & \begin{tabular}{|c|} 
Jousé (1948, \\
1949, 1951, \\
1955); Krotov \\
(1957a,b, 1959); \\
Krotov and \\
Schibkova \\
(1961), \\
Schibkova \\
(1961), \\
Strelnikova \\
$(1964,1965 a, b$, \\
$1966 a, b, 1968$, \\
1971,1974, \\
$1975) ;$ \\
Vekschina \\
(1961a,b)
\end{tabular} & $\begin{array}{l}\text { Ural Mountains } \\
\text { and western } \\
\text { Siberian } \\
\text { lowland, Russia }\end{array}$ & $\begin{array}{l}\text { Good to } \\
\text { excellent }\end{array}$ & $\begin{array}{c}\text { Taxonomy, } \\
\text { biostratigraphy } \\
\text { approach }\end{array}$ \\
\hline $\begin{array}{l}\text { Campanian to } \\
\text { Maastrichtian }\end{array}$ & $\begin{array}{c}\text { Bergstresser and } \\
\text { Krebs (1983) }\end{array}$ & $\begin{array}{c}\text { Wyoming, } \\
\text { Colorado, and } \\
\text { Kansas }\end{array}$ & Pyritized & Pienre Shale \\
\hline $\begin{array}{c}\text { Late Campanian } \\
\text { to early } \\
\text { Maastrichtian }\end{array}$ & \begin{tabular}{|c|} 
Takahashi et al., \\
(1999)
\end{tabular} & $\underset{\substack{\text { NW Kanto Mts., } \\
\text { Japan }}}{ }$ & Poor & $\begin{array}{c}\text { Shoya } \\
\text { Formation }\end{array}$ \\
\hline $\begin{array}{l}\text { Carmpanian to } \\
\text { Danian }\end{array}$ & $\begin{array}{c}\text { Martinez- } \\
\text { Machiavello } \\
\text { (1987); } \\
\text { Harwood (1988) }\end{array}$ & $\begin{array}{l}\text { Seymour Island, } \\
\text { Antarctic } \\
\text { Peninsula }\end{array}$ & $\begin{array}{l}\text { Poor to } \\
\text { moderate }\end{array}$ & \begin{tabular}{|c|} 
Biostratigraphy, \\
K/T boundary. \\
Lopez de \\
Bertodano and \\
Sobral \\
Formations. \\
\end{tabular} \\
\hline $\begin{array}{c}\text { Late } \\
\text { Maastrichtian }\end{array}$ & \begin{tabular}{|c} 
Hanna (1927, \\
1934); Long et \\
al. (1946); \\
Barker \& \\
Meakin (1944, \\
1945, 1946, \\
1948, 1949); \\
Brigger \& \\
Hanna (1965), \\
Hasle \& \\
Syverten (1985), \\
Ross \& Sims \\
(1985, 1997), \\
Sims (1986, \\
1989, 1994a,b), \\
Sims \& Hasle \\
(1987), Sims \& \\
Ross (1988), \\
Nikolaev et al. \\
(2001). \\
\end{tabular} & $\begin{array}{c}\text { Fresno County, } \\
\text { California }\end{array}$ & Good & $\begin{array}{l}\text { Taxonony, } \\
\text { Moreno } \\
\text { Formation }\end{array}$ \\
\hline Maastrichtian & $\begin{array}{l}\text { Wiedmann } \\
\text { (1964) }\end{array}$ & $\begin{array}{l}\text { de la Manche } \\
\text { Valley, } \\
\text { Rougemont, } \\
\text { Swiss Alps } \\
\end{array}$ & Pyritized & - \\
\hline Maastrichtian & Abbott (1978) & South Carolina & Pyritized & $\begin{array}{c}\text { Pee Dee } \\
\text { Formation }\end{array}$ \\
\hline Maastrichtian & Ferner (1982) & Emperor Canyon & Moderate & $\begin{array}{c}\text { Off New Jersey } \\
\text { coast }\end{array}$ \\
\hline $\begin{array}{c}\text { Early } \\
\text { Maastrichtian }\end{array}$ & $\begin{array}{c}\text { Shipboard } \\
\text { Scientific Party } \\
\text { (1989), Nikolacv } \\
\text { \& Harwood } \\
\text { (2000) }\end{array}$ & $\begin{array}{l}\text { ODP Leg } 120, \\
\text { Site } 748\end{array}$ & Moderate & $\begin{array}{c}\text { Kerguelen } \\
\text { Plateau, South } \\
\text { Indian Ocean }\end{array}$ \\
\hline $\begin{array}{l}\text { Cenomanian? to } \\
\text { Campanian }\end{array}$ & $\begin{array}{c}\text { Tapia } \\
1996,1997 \text {, and } \\
\text { this report }\end{array}$ & $\begin{array}{c}\text { Slidre Fjord, } \\
\text { Hoodoo Dome, } \\
\text { Cape Nares, and } \\
\text { Horton River } \\
\text { sections }\end{array}$ & Moderate & $\begin{array}{l}\text { Arctic Canada, } \\
\text { biostratigraphy } \\
\text { and } \\
\text { paleoecology }\end{array}$ \\
\hline
\end{tabular}

is distinguished by the presence of Stephanopyxis turris, Triceratium anissimovae, Paralia sulcata, Pseudopodosira simplex, $P$. punctata, Skeletonema polychaetum, Costopyxis broschii, Aulacodiscus archangelskianus, A. bifrons, Hemiaulus antiquus, H. kittonii, Gladius speciosus f. speciosus, Pterotheca aculeifera, and P. evermannii. The Third Complex (light gray diatomaceous clays, upper part of the Upper Campanian) is characterized by Paralia sulcata, Pseudopodosira aspera, Stephanopyxis turris, S. lavrenkoi, Costopyxis reticulata, Aulacodiscus jouseae, Triceratium planum, T. coronatum, Gladius speciosus f. aculeatus and f. poratus, and Pseudopyxilla rossica. The Prunobrachium articulatum radiolarian complex and the foraminiferal Bathysiphon nodosariaformis Zone provide biostratigraphic control that indicates a Late Campanian age for the Second and Third diatom complexes (Strelnikova 1975).

Deep Sea Drilling Project Leg 29, Site 275, SW Pacific Ocean. DSDP Site 275 recovered $17.5 \mathrm{~m}(40.6 \%)$ of sediment from a $43 \mathrm{~m}$-thick cored section on the Southeast Campbell Plateau $\left(50^{\circ} 26^{\prime} \mathrm{S}, 176^{\circ} 19^{\prime} \mathrm{E}\right)$. Two cores containing $13 \mathrm{~m}$ of glauconitebearing silty, radiolarian-diatomaceous ooze recorded the Late Cretaceous diatom history in the Southwest Pacific Ocean (text-fig. 3-B). A Late Campanian age was determined by correlation with the uppermost Campanian radiolarian Patulibracchium dickinsoni Zone of California and by palynological correlation to New Zealand and Campbell Island, which suggested a Late Campanian to Maastrichtian age (Shipboard Scientific Party 1975). The diatom record indicates a Late Campanian to Maastrichtian age, whereas silicoflagellates indicate a Late Cretaceous (probably Maastrichtian) age (PerchNielsen 1975). Extraordinarily well-preserved diatom and silicoflagellate assemblages were encountered in Cores 1 and 2. Hajós and Stradner (1975) examined twenty samples and proposed nine biostratigraphic zones for this $13 \mathrm{~m}$-thick section. In ascending order the zones are the Horodiscus rugosus Zone, Chasea ornata Zone, Epithelium rossicum Zone, Anaulus subantarcticus Zone, Biddulphia sparsepunctata Zone, Kentrodiscus armatus Zone, Cerataulus-Odontotropis Zone, Acanthodiscus antarcticus Zone, and Pseudopyxilla jouseae Zone.

Although many diatom taxa present at Site 275 are also noted in the Canadian Arctic sediments, other key taxa, including those used as stratigraphic markers, are not present in the Arctic diatom flora. For this reason, the zonation of Hajós and Stradner (1975) cannot be applied in the present study.

\section{Geological setting of the Upper Cretaceous Canadian Arctic}

Samples examined in this study came from two different geological settings. Samples from the Arctic Islands belong to the Sverdrup Basin, whereas those from the continental margin belong to the Anderson Plain Syncline (Yorath et al. 1975, Plauchut and Jutard 1976). The Sverdrup Basin developed by rifting during the mid-Carboniferous and was filled by up to 9000m of Mesozoic sediment. Upper Cretaceous strata of the Kanguk and Expedition formations rest unconformally upon Lower Cretaceous rocks. A diachronus unconformity (Late Albian-Late Cenomanian) is present throughout the basin. A major Late Cenomanian transgression transformed the Arctic Island region in an offshore shelf. By the end of the Cretaceous, sediment supply increased and the region was occupied by pro-delta and fluvial-deltaic plains (Embry 1991). In the Anderson Plain Syncline, Mesozoic strata rest unconformably on a Paleozoic sequence and are unconformably overlain by the Up- 

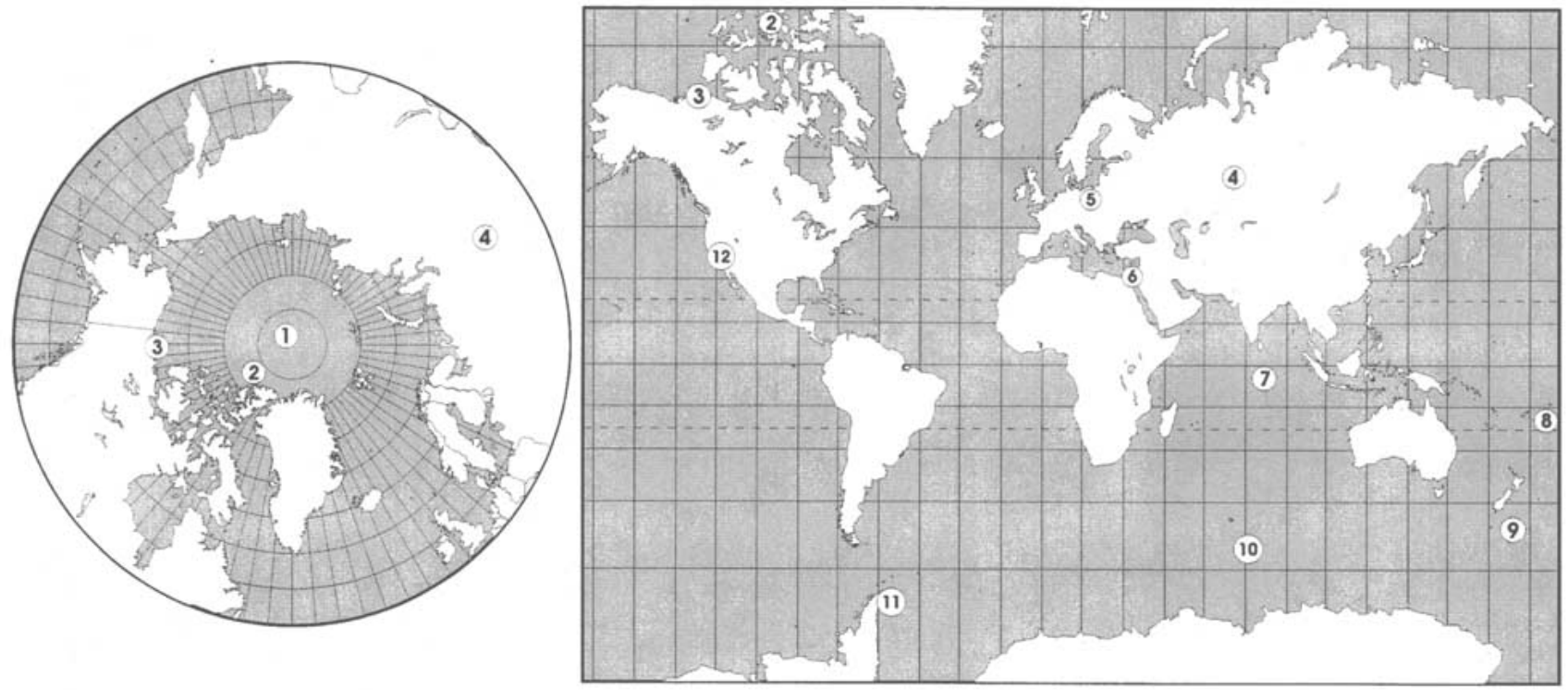

TEXT-FIGURE 1

Global distribution of selected Campanian-Maastrichtian diatomaceous deposits (See Table 1). 1= Alpha Ridge, Arctic Ocean; $2=$ Arctic Archipelago, Canada (this study); $3=$ Northern Continental Margin, Canada (this study); 4= Ural Mountains, Russia; 5= Gdansk, Poland; 6= Central Negev, Israel; $7=$ Ninetyeast Ridge, Indian Ocean; 8= Tonga Trench, Pacific Ocean; 9= Campbell Plateau, Pacific Ocean; 10= Kerguelen, Plateau, Southern Ocean; $11=$ Seymour Island, Antarctica; 12= Moreno Gulch, California.

per Tertiary Beaufort Formation. The Upper Cretaceous sequence is represented by the Smoking Hills and Mason River formations of the Amudsen Gulf Group (Yorath et al. 1975).

\section{MATERIALS AND METHODS}

Cretaceous siliceous microfossils in the Canadian Arctic Archipelago (Banks Island) were first identified as reworked elements in glacial sediments (Vincent et al. 1983) from the Duck Hawk Bluff, Morgan Bluff, Nelson River, and Prince of Wales formations. That report stimulated the present study.

Four stratigraphic sections within the Canadian Arctic Archipelago and continental margin were examined (text-fig. 4, columns A-D). Samples were collected by scientists from the Geological Survey of Canada (GSC) (P. T. Chamney, A. F. Embry, J. C. Harrison, and J. H. Wall) and kindly provided by David McNeil of the GSC. From these sections, one hundred and twelve samples were analyzed to determine the presence of siliceous microfossils. Forty-nine of these contained enough siliceous microfossils to warrant a detailed diatom survey (text-fig. 4).

Slidre Fjord, Ellesmere Island, District of Franklin. The Slidre Fjord GSC section $74 \mathrm{RV}-38$ is located at $79^{\circ} 47.4^{\prime} \mathrm{N}, 85^{\circ} 22^{\prime} \mathrm{W}$ (text-fig. 2, site 2a; J. H. Wall, pers. comm.). A total of 29 samples were examined from the $260.5 \mathrm{~m}$-thick Kanguk Formation (text-fig. 4, column A). There is no available section description or stratigraphic column from this locality. At an adjacent site (GSC locality 79 EL-3, Remus Creek, Fosheim Peninsula, Ellesmere Island), the Kanguk Formation unconformably overlies the Upper Albian to Cenomanian Hassel Formation (Wall 1983 ) and consists of approximately $220 \mathrm{~m}$ of dark-gray shale with minor amounts of siltstone and sandstone. Thin bentonite seams are characteristic of the lower part of this formation. Macrofossils do not provide reliable age control at this site, but Lower Santonian ammonites are reported from this formation at the head of Slidre Fjord on Fosheim Peninsula (Jeletzky in Wall 1983). Foraminiferal data indicate an age range from Turonian to Late Campanian (Wall 1983). The depositional environment of the Kanguk Formation at Slidre Fjord is interpreted to be marine of shallow to moderate depth on the shelf (J. H. Wall, pers. comm.).

Hoodoo Dome, Ellef Ringnes Island, District of Franklin. Hoodoo Dome is a double-plunging anticline, cored and pierced locally by a Carboniferous halite diapir (Stott 1969). The 12 samples examined here came from the 390m-thick Kanguk Formation at Hoodoo Dome, GSC section 73BAA-10002 (text-fig. 2 , site 2 b; text-fig. 4, column B). Unfortunately, no section description or stratigraphic column is available from this locality. Other studies of the Kanguk Formation at Hoodoo Dome (Blakwill 1974, Blakwill and Hopkins 1976) report a thickness of about $450 \mathrm{~m}$, dividing this lithostratigraphic unit into two informal (lower and upper) members based on the presence of an escarpment-forming, red-brown siltstone between those units. The lower member comprises about $240 \mathrm{~m}$ of soft, slightly silty, pyritic, black shale with abundant thin beds and laminations of yellow-gray jarositic clay. Near the base of this section, the beds are pink and brick-red due to the oxidation of iron-sulfide minerals. No macrofossils are known from this member, however the presence of mollusks Watinoceras sp. and the recognition of the Mytiloides labiatus Zone at the same stratigraphic level on the adjacent Amund Ringnes Island indicates an Early Turonian age for the lower unit (Jeletzky in Blakwill and Hopkins 1976). The upper member comprises circa $210 \mathrm{~m}$ of dark-brown-gray shaly siltstone and silty shale, with abundant small red-brown ironstone nodules and a few jarositic clay beds. A collection of well-preserved mollusks suggests the base of the upper unit is late Early or early Late Santonian in age (Jeletzky in Blakwill and Hopkins 1976). The depositional environment of the Kanguk Formation at Hoodoo Dome represents a middle outer 


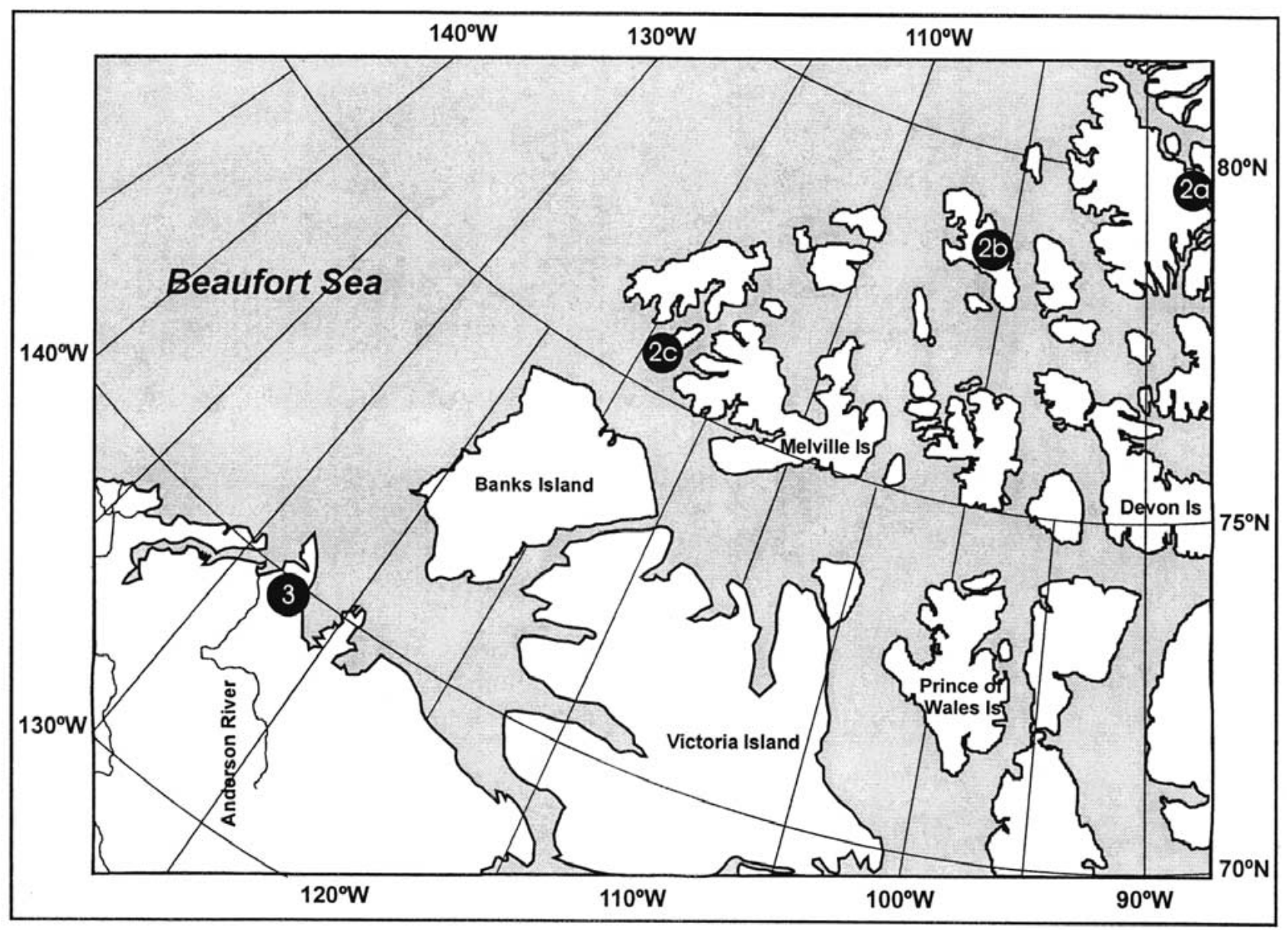

TEXT-FIGURE 2

Diatomaceous deposits in the Canadian Arctic (areas 2 and 3 in Fig. 1). 2a=Slidre Fjord, Ellesmere Island; 2b= Hoodoo Dome, Ellef Ringnes Island; $2 \mathrm{c}=$ Cape Nares, Eglinton Island; $3=$ Horton River, Northwest Territories.

shelf setting in the lower unit and an upper shelf to pro-delta setting in the upper unit (Blakwill and Hopkins 1976).

Cape Nares, Eglinton Island, District of Franklin. The Cape Nares section (GSC 87EL-16) is located at $75^{\circ} 38^{\prime} \mathrm{N}, 119^{\circ} 22^{\prime} \mathrm{W}$ (text-fig. 2, site 2c; J. H. Wall, pers. comm.). The 20 samples examined here came from a $156 \mathrm{~m}$ measured section of the Kanguk Formation at Cape Nares (text-fig. 4, column C). No section description or stratigraphic column is available from this locality. The Kanguk Formation at Eglinton Island was studied by Plauchut and Jutard (1976), who reported a 312 m-thick unit unconformably overlying the Upper Albian Hassel Formation. The Kanguk Formation is divided into three members: the Lower Shale, Eglinton Sandstone, and Upper Shale members. (1) The Lower Shale Member is $200 \mathrm{~m}$-thick and contains two units; the lower part $(110 \mathrm{~m})$ comprises gray to black shale, silt and sandstone with thin bands of yellow jarosite and concretionary masses of mudstone and dark ironstone, and the upper part $(90 \mathrm{~m})$ comprises brown to black shale and minor silt with thin bands of gray and green sand, which increase in abundance toward the top of the unit. (2) The Eglinton Sandstone Member is 50m-thick and comprises green, gray or whitish, indurated, medium to coarse quartz sandstone, gravel and conglomerate. The contact between the Eglington and Lower Shale members is transitional. (3) The Upper Shale Member is $62 \mathrm{~m}$-thick and comprises gray to gray-brown shale, silty shale and sandstone with a few beds of brown ferruginous sandstone. The age of the Kanguk Formation at Eglinton Island is Santonian to Campanian, based on fossil mollusks (Jeletzky in Plauchut and Jutard 1976) and Senonian based on fossil radiolaria and foraminifera (Fischer in Plauchut and Jutard 1976). The Lower Shale and Eglinton members are considered to be Upper Turonian to Lower Campanian based on the presence of the foraminiferal Dorotia smokyensis assemblage and Trocammina ribstonensis (J. H. Wall, pers. comm.). The depositional environment is interpreted to be nearshore to open marine for the lower part of the Lower Shale Member and a shallow to moderate depth marine shelf environment for the rest of the formation (Plauchut and Jutard 1976, J. H. Wall, pers. comm.).

Horton River Section, District of Mackenzie, Northwest Territories. The Horton River sequence is a composite section constructed from three adjacent outcrops on the Anderson Plains (text-fig. 2, area 3). The 51 samples examined here came from these three outcrops of the Smoking Hills and Mason River formations (text-fig. 4, column D). No section descriptions or stratigraphic columns are available from any of these 3 localities. (1) The GSC location CR 16A-N68 (69 27'30"N, $126^{\circ} 58^{\prime} \mathrm{W}$ ) represents the Smoking Hills Formation (McIntyre 1974, Yorath et al. 1975). This formation disconformably overlies the mid Albian Horton River Formation, and comprises ap- 
(A)

(B)

Ural Mts, Russia (Strelnikova 1974, 1975)

\section{Diatom Complexes}

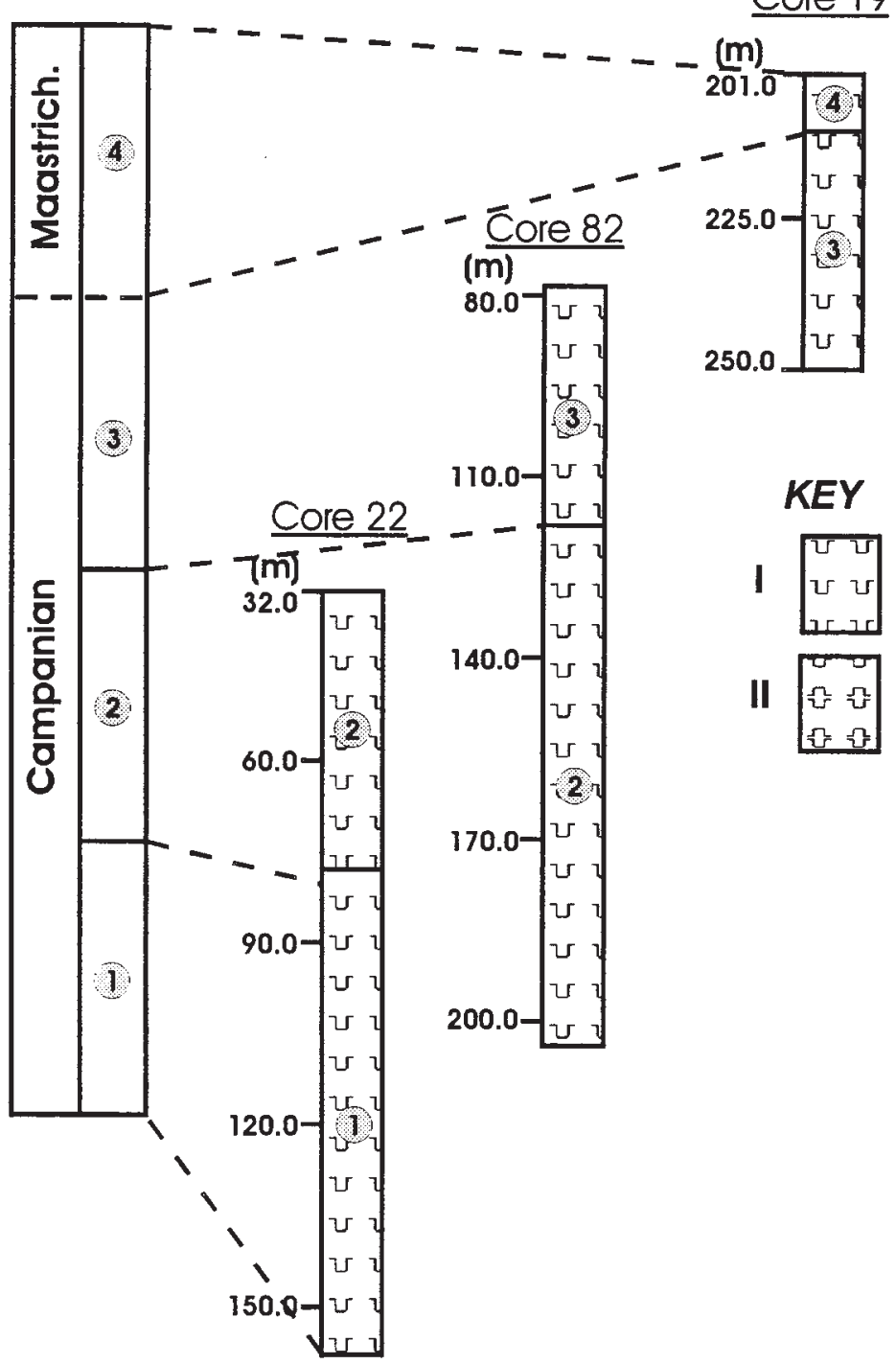

Campbell Plateau, SW Pacific (Hajos \& Stradner, 1975)

Diatom DSDP Site 275
Biostrat.

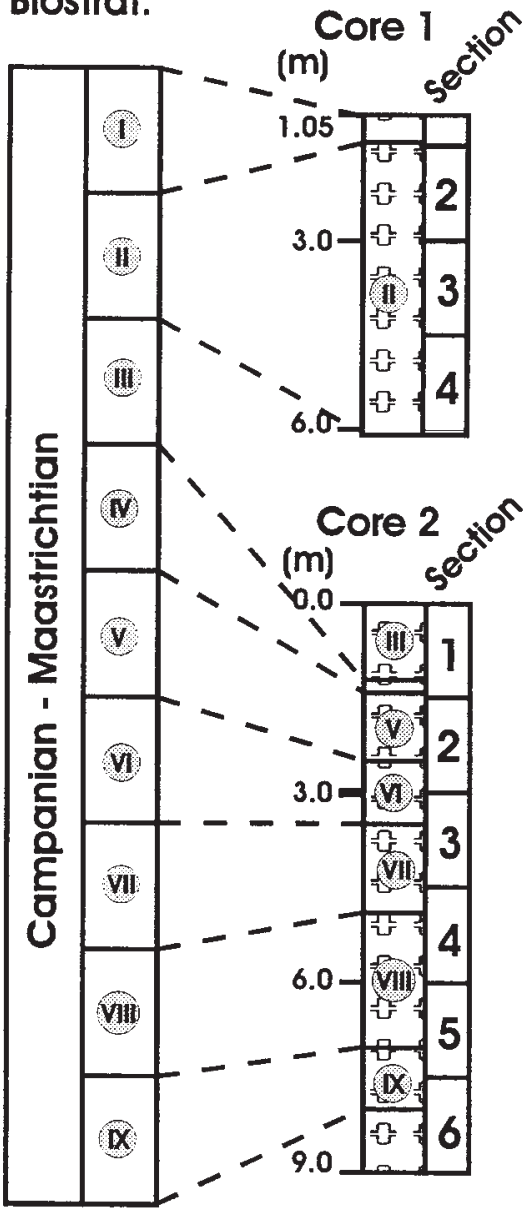

\section{TEXT-FIGURE 3}

Upper Cretaceous diatom biostratigraphy in (A) Ural Mts., Russia (from Strelnikova 1974), and (B) Campbell Plateau, SW Pacific (from Hajós \& Stradner 1975). Note the different scales. Strelnikova (1974) divided Russian cores into 4 biostratigraphical divisions: $1=$ First Diatom Complex, $2=$ Second Diatom Complex, 3= Third Diatom Complex, 4= Complex with Stephanopyxis biseriata and Triceratium cellulosum; Hajós \& Stradner (1975) erected 9 zones for two cores in DSDP Site 275: $\mathrm{I}=$ Pseudopyxilla jouseae Zone, $\mathrm{II}=$ Acanthodiscus antarcticus Zone, III=Cerataulus-Odontotropis Zone, IV= Kentrodiscus armatus Zone, V= Biddulphia sparsepunctata Zone, VI= Anaulus subantarcticus Zone, VII= Epithelium rossicum Zone, VIII= Chasea ornata Zone, and IX= Horodiscus rugosus Zone. Key: I= Diatomite and diatomaceous mudstone, II= Radiolarian and diatomaceous ooze.

proximately $100 \mathrm{~m}$ of a variable sequence of black, bituminous shale, bedded yellow jarosite, and locally dark maroon beds of earthy hematite (Yorath et al. 1969, McIntyre 1974). The Smoking Hills Formation is considered Lower Campanian based on vertebrate fauna (Russell 1967) and Santonian to Campanian based on palynomorphs (McIntyre 1974). The depositional environment is interpreted to be nearshore to open marine (Plautchut and Jutard 1976). (2) The GSC location CR 
(B)

HOODOO DOME
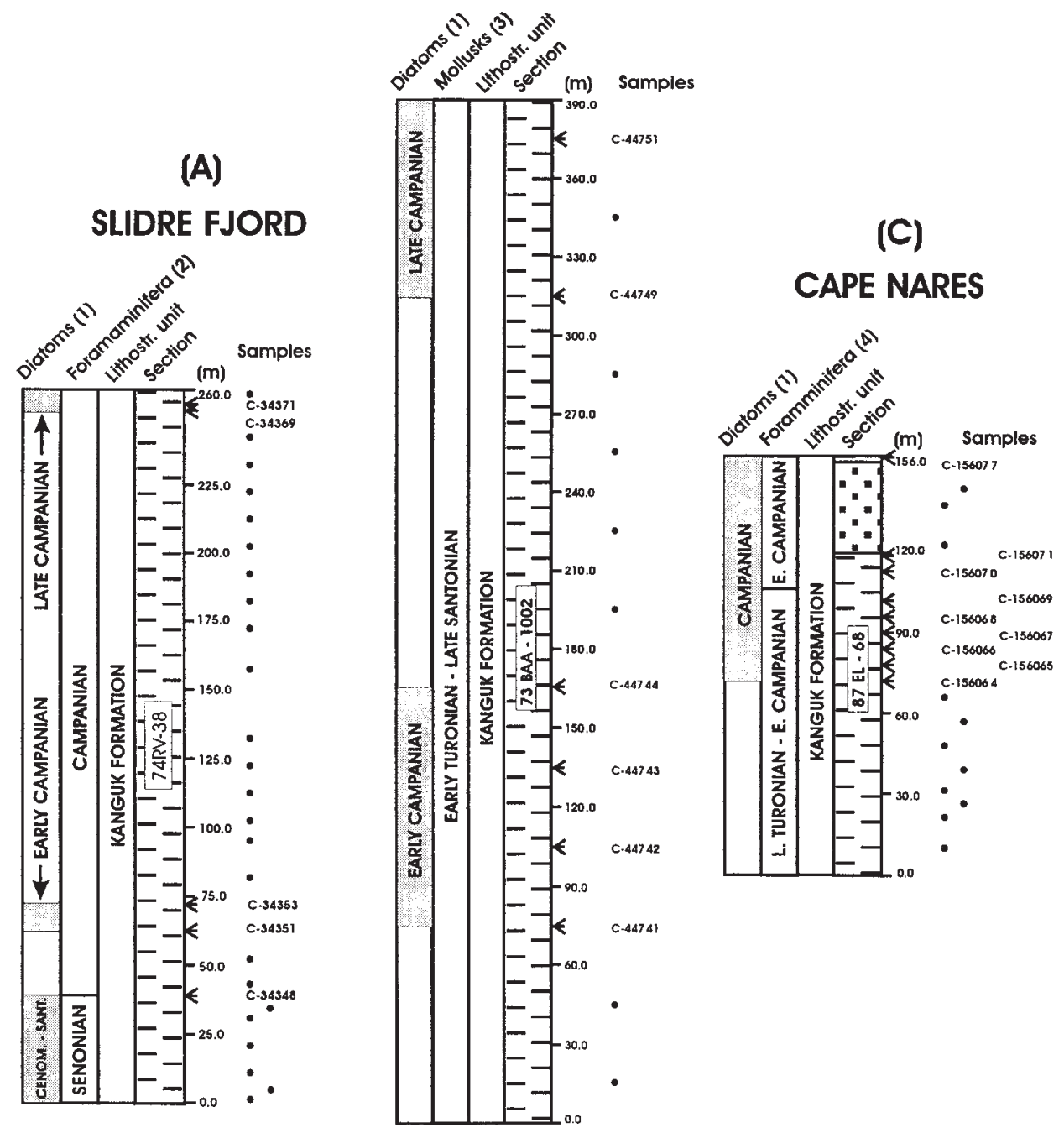

TEXT-FIGURE 4

Schematic stratigraphic columns of the studied sections. The positions of diatom-bearing samples are indicated by small arrows and GSC sample codes (e.g. C-34348). Barren samples postions are marked by small dots. A = Slidre Fjord, Ellesmere Island; B = Hoodoo Dome, Ellef Ringes Island; C= Cape Nares, Eglington Island; D = Horton River, NWT. Numbers within the lithologic columns are GSC codes for stratigraphic sections. $1=$ Diatom biostratigraphy (this study); 2 and 4 = J. H. Wall (personal communication); 3 = Blakwill \& Hopkins (1976); 5 = McIntyre (1974).

$16 \mathrm{~B}-\mathrm{N} 68\left(69^{\circ} 28^{\prime} \mathrm{N}, 126^{\circ} 58^{\prime} \mathrm{W}\right)$ represents part of the Mason River Formation (McIntyre 1974), which at this locality is approximately $125 \mathrm{~m}$-thick and comprises a lower unit composed of pale gray-weathering shale with minor amounts of mudstone and rusty, dark ferruginous dolomite concretionary beds. This is overlain by a middle unit of medium to locally dark gray shale with some gypsum; and an upper unit of medium to dark-gray-brown and brown ferruginous shale that grades upward into gray sandy shale (Yorath et al. 1969, McIntyre 1974). The Mason River Formation gradationally and conformably overlies the Smoking Hills Formation and is unconformably overlain by a Recent unconsolidated gravel and sand unit (Plautchut and Jutard 1976). (3) The GSC location CR 17A-N68 $\left(69^{\circ} 58^{\prime} 30^{\prime \prime} \mathrm{N}, 127^{\circ} 4^{\prime} \mathrm{W}\right)$ represents the upper part of the Mason River Formation, measuring approximately $62 \mathrm{~m}$
(McIntyre 1974). The Mason River Formation was dated as Campanian to Maastrichtian based on palynomorph biostratigraphy (McIntyre 1974) and the depositional environment is thought to be marine shelf with minor continental influences (Plautchut and Jutard 1976).

Sample preparation. Approximately 1cc of unconsolidated sediment was placed into a $1000 \mathrm{ml}$ beaker and dried on a hot plate. After the beaker cooled, 10-20ml of concentrated hydrochloric acid and $40-50 \mathrm{ml}$ of $30 \%$ hydrogen peroxide were added. This solution was heated and left to react until the strong reaction ceased. The beaker was then filled with filtered water and $10 \mathrm{ml}$ of $5 \%$ Calgon solution, stirred, and left to settle overnight. The next day, the supernatant solution (approximately 3/4 parts of the volume) was decanted. The beaker was refilled with filtered 
TABLE 2

Selected diatom data (total counts) from Slidre Fjord Section of both size-fractions (greater and lesser than 25m). Preservation: $\mathrm{G}=\mathrm{Good}, \mathrm{M}=\mathrm{Moderate}$, $\mathrm{P}=$ Poor; Relative Abundance: $\mathrm{A}=$ Abundant, $\mathrm{C}=$ Common, $\mathrm{F}=\mathrm{Few}, \mathrm{R}=$ Rare.

\begin{tabular}{|c|c|c|c|c|c|c|c|c|c|c|c|c|c|c|}
\hline & & \begin{tabular}{|c|}
$\begin{array}{c}\text { Cenom - } \\
\text { Sant. }\end{array}$ \\
\end{tabular} & $\begin{array}{r}\mathrm{E} \\
\text { Cam } \\
\end{array}$ & anian & $\begin{array}{l}\text { Early } \\
\text { Camp }\end{array}$ & $\begin{array}{l}\text { Late } \\
\text { anian }\end{array}$ & & & \begin{tabular}{c|} 
Cenom - \\
Sant.
\end{tabular} & $\begin{array}{r}\mathrm{E} \\
\text { Camr }\end{array}$ & nian & $\begin{array}{c}\text { Early-Late } \\
\text { Campan. }\end{array}$ & & \\
\hline & 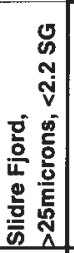 & 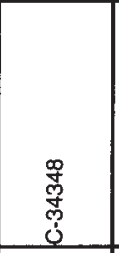 & 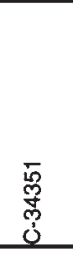 & 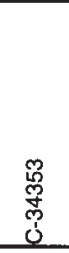 & 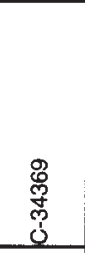 & $\begin{array}{l}\bar{T} \\
\text { 耪 } \\
\text { d }\end{array}$ & 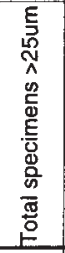 & 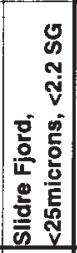 & 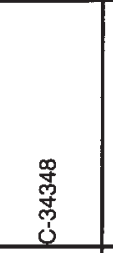 & $\begin{array}{l}\overline{5} \\
\stackrel{5}{\tilde{S}} \\
\dot{\delta}\end{array}$ & 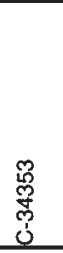 & 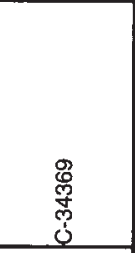 & 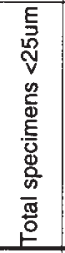 & 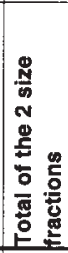 \\
\hline Outcrop elevation (m) & & 39 & 62.5 & 72 & 252.5 & 254.5 & & & 39 & 62.5 & 72 & 252.5 & & \\
\hline Preservation & & $M$ & $\mathbf{P}$ & $M$ & $M$ & $\mathrm{P}$ & & & $M-P$ & $M-P$ & $\mathrm{P}$ & $P$ & & \\
\hline Abundance & & c & C & C-F & $\mathrm{F}$ & $\mathrm{R}$ & & & $\mathrm{R}$ & $\mathrm{F}$ & $\mathrm{R}$ & $F-R$ & & \\
\hline Actinoptychus heterostrophus & & & & 43 & & & 43 & & & 19 & & & 19 & 62 \\
\hline Actinoptychus tenuis & & & & 5 & & & 5 & & & & & & 0 & 5. \\
\hline Aulacodiscus septus f. septus & & & & 2 & 6 & 1 & 9 & & & & 1 & & 1 & 10 \\
\hline Basilicostephanus sp. 1 & & 8 & & 93 & & & 101 & & 12 & 106 & & & 118 & 219 \\
\hline Bilingua sp. 1 & & & & & & & 0 & & 1 & & & & 1 & 1 \\
\hline Corinna sp. 1 & & 4 & & 2 & & & 6 & & & & & & 0 & 6 \\
\hline Cortinocornus rossicus & & & & & & & 0 & & & & 1 & 1 & 2 & 2 \\
\hline Costopyxis antiqua & & & 4 & 2 & & & 6 & & & & & & 0 & 6 \\
\hline Costopyxis ornata & & 4 & & & 5 & 2 & 11 & & & & & 28 & 28 & 39 \\
\hline Costopyxis shulzii f. shulzii & & 30 & 124 & 9 & 16 & 3 & 182 & & 4 & & & 24 & 28 & 210 \\
\hline Costopyxisshulzii var. nuda & & 12 & & & & & 12 & & 15 & & & & 15 & 27 \\
\hline Gladiopsis speciosus f. aculeolatus & & & & 2 & & & 2 & & 2 & & & & 2 & 4 \\
\hline Gladiopsis speciosus f. speciosus & & 3 & 62 & & & & 65 & & & & & 30 & 30 & 95 \\
\hline Gladius antiquus & & 1 & & & & & 1 & & 9 & & & & 9 & 10 \\
\hline Hemiaulus antiquus & & & & & & & 0 & & 1 & & & 2 & 3 & 3 \\
\hline Hemiaulus echinulatus & & 1 & & & & & 1 & & 2 & & & & 2 & 3 \\
\hline Hemiaulus elegans & & 1 & & & & 1 & 2 & & & & & & 0 & 2 \\
\hline Hemiaulus polymorphus var. frigida & & 1 & 1 & & & & 2 & & & & 1 & & 1 & 3 \\
\hline Hemiaulus schmidti & & 4 & & & & & 4 & & & & & & 0 & 4 \\
\hline Hemiaulus sp. A & & 2 & & & & & 2 & & 2 & & $t$ & & 3 & 5 \\
\hline Hemiaulus sporalis (spores) & & & 4 & & & & 4 & & & & & & 0 & 4 \\
\hline Lepidodiscus elegans & & & & 2 & & & 2 & & & & & & 0 & 2 \\
\hline Micrampula parva & & 1 & & & & & 1 & & & & & & 0 & 1 \\
\hline Paralia ornata & & 36 & & & 12 & 2 & 50 & & 26 & 4 & 20 & & 50 & 100 \\
\hline Paralia sulcata & & 19 & & 32 & 10 & & 61 & & 6 & 35 & 16 & 6 & 63 & 124 \\
\hline Pseudopyxilla sp. cf. P. rossica & & 1 & & & & & 1 & & & & & & 0 & 1 \\
\hline Pterotheca aculeifera & & & & & 1 & & 1 & & & & 1 & & 1 & 2 \\
\hline Stellarima stenyi & & 3 & & & & & 3 & & & & & & 0 & 3 \\
\hline Stepahnopyxis arctica & & & & & & 2 & 2 & & & & & & 0 & 2 \\
\hline Stephanopyxis grunowi & & 5 & & & 2 & & 7 & & & & & & 0 & 7 \\
\hline Stephanopyxis sp. A & & 5 & & 1 & & & 6 & & & & & & 0 & 6 \\
\hline Stephanopyxis turris & & & & & 1 & & 1 & & & & & & 0 & 1 \\
\hline Thalassiosiropsis wittiana & & & & & 1 & & 1 & & & & & & 0 & 1 \\
\hline Trinacria acutangulum & & & & & & & 0 & & & & 2 & & 2 & 2 \\
\hline Trinacria indefinita & & & & & 1 & & 1 & & & & & & 0 & 1 \\
\hline Trochosira denticulatum & & 22 & & & & & 22 & & & & & & 0 & 22 \\
\hline Trochosiropsis polychaeta & & 12 & & & & & 12 & & 2 & & & & 2 & 14 \\
\hline Other diatoms (including resting spores) & & 14 & 12 & 19 & 4 & 2 & 51 & & 4 & 4 & 1 & 2 & 11 & 62 \\
\hline TOTAL DIATOMS & & 189 & 207 & 212 & 59 & 13 & 680 & & 86 & 168 & 44 & 93 & 391 & 1071 \\
\hline
\end{tabular}

water, allowed to settle for 6 hours and then decanted. This procedure was repeated four times to wash out the hydrochloric acid, hydrogen peroxide and Calgon, as well as to remove the finer clay size-fraction. The cleaned sample was then filled with filtered water, stirred vigorously, and allowed to settle for 5 minutes. This time the supernatant solution was sieved through a $25 \mu \mathrm{m}$ mesh and the finer fraction was collected in two $2000 \mathrm{ml}$ beakers. This step was repeated four times or until the supernatant water was clear after five minutes of settling. The sample of size $25 \mu \mathrm{m}$ was saved in a $10 \mathrm{ml}$ vial. The $25 \mu \mathrm{m}$ size fraction was saved in a $125 \mathrm{ml}$ Nalgene bottle after the fine sediment in the beakers settled overnight, and the supernatant water was decanted. The coarse (=heavy) sediment residue that remained in the $1000 \mathrm{ml}$ beaker after the 5 minute gravitational settling period was dried in an electrical oven at $75^{\circ} \mathrm{C}$ and then saved in a labeled plastic sample bag.

Strewn slides of the $25 \mu \mathrm{m}$ size fraction were made for the entire set of samples in order to identify productive samples for siliceous microfossil analysis, and to determine if more chemical 


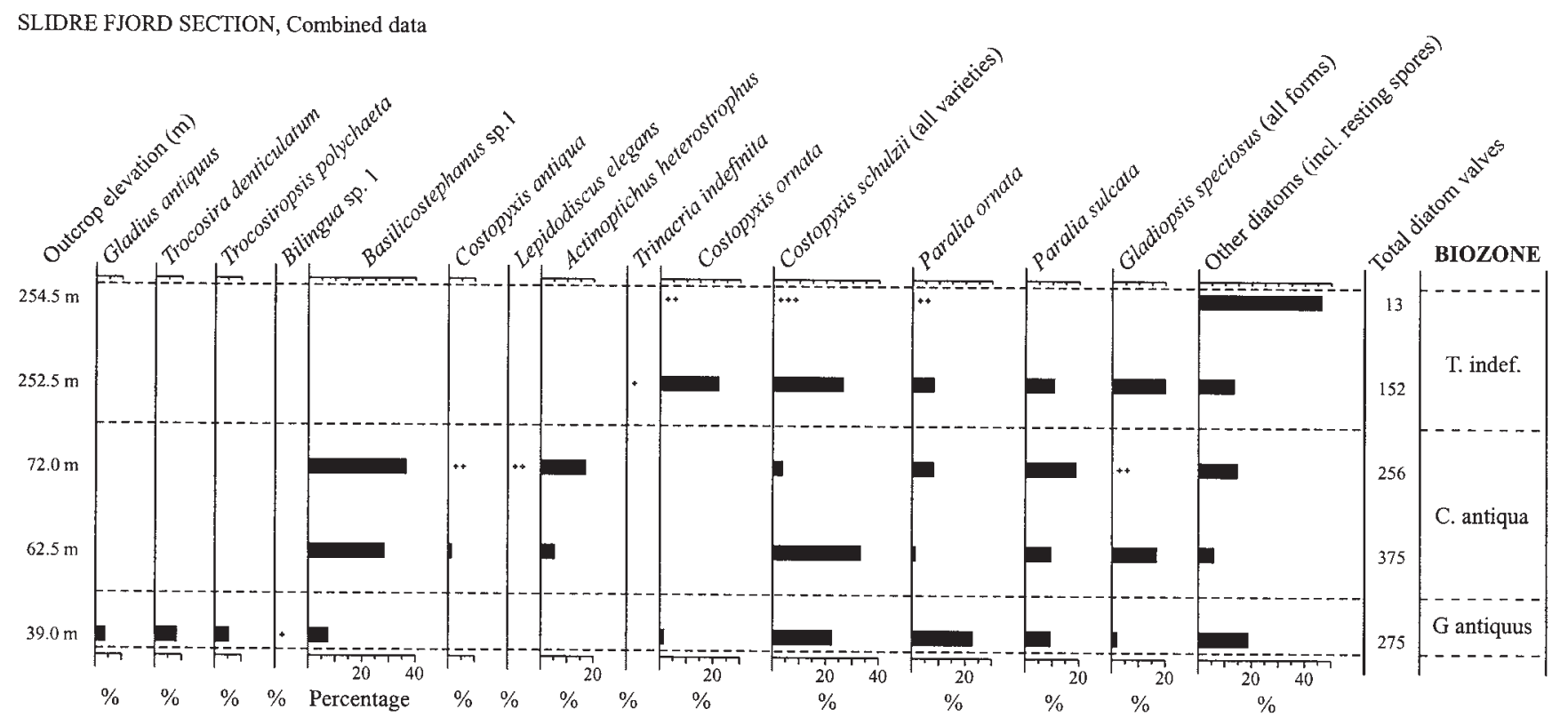

TEXT-FIGURE 5

Diatom stratigraphy of selected diatom taxa in the Slidre Fjord section. Relative abundances (percentage) of taxa were calculated after the combined data (sum of greater and lesser than 25 micrometer fractions). Crosses indicate rare occurrences (usually $<1 \%$ ).

treatment was needed. The samples containing siliceous microfossils were then concentrated by floating with the heavy liquid sodium polytungstate (SPT) at a density of $2.2 \mathrm{~g} / \mathrm{cc}$.

The sodium polytungstate flotation technique requires the previous chemical treatment in order to release the diatoms from the sediment matrix and clean the frustules. The acid-resistant subsample was then resuspended in $10 \mathrm{ml}$ of distilled water. To begin the floatation, $3.5 \mathrm{ml}$ of SPT $(=2.2 \mathrm{~g} / \mathrm{cc})$ was placed in the bottom of a $15 \mathrm{ml}$ disposable centrifuge tube. The subsample was resuspended and the $10 \mathrm{ml}$ suspension was carefully added to the top of the SPT in order to prevent mixing of these two solutions. The centrifuge tube was then filled up with distilled water and centrifuged at low speed $(500 \mathrm{rpm})$ for 3 minutes. The SPT/water interface was carefully pipetted out and placed into another centrifuge tube. To remove the SPT from the diatom frustules, the working aliquot was resuspended in $15 \mathrm{ml}$ of distilled water and centrifuged at $1500 \mathrm{rpm}$ for 3 minutes. The residue was washed again, up to four times or until all of the SPT was removed. The cleaned subsample was stored into a $10 \mathrm{ml}$ labeled vial.

Permanent slides were made for both size fractions (greater and lesser than $25 \mu \mathrm{m}$ ) using cleaned, $22 \times 40 \mathrm{~mm}$, cover slides. The cover slide was placed on a warm hot plate and six to eight drops of distilled water were added. One or two drops of the concentrated subsample were placed into the water at the middle of the slide and then two to three drops of alcohol (ethanol) were added. Alcohol helped disperse the sample across the slide. Two to three drops of mounting medium Norland Optical Adhesive \# 61 (R.I. 1.56), was placed on a clean, labeled, $25 \times 75 \mathrm{~mm}$, microscope slide. The microscope slide was fixed over the dried cover slip, and then flipped over to warm the Norland Optical Adhesive for a few minutes on the hot plate to reduce the media's viscosity and assure effective impregnation throughout the diatom valves. Finally, these permanent slides were cured under ultraviolet light for 15-20 minutes.

The slides were examined using an Olympus BH-2 Transmitted Light Microscope with Differential Interference Contrast. Photomicrographs were taken using B/W Technical Pan Kodak film, ASA 25. Data was collected at magnification $\times 500$ (fraction $>25 \mu \mathrm{m}$ ), and $750 \mathrm{X}$ (fraction $<25 \mu \mathrm{m}$ ). Final identifications were made at magnification $\times 1250$. Specimens were counted following the convention stated in Schrader and Gersonde (1978). A total of 500 specimens were counted per sample, 300 in the fraction $>25 \mu \mathrm{m}$ and 200 at the fraction $<25 \mu \mathrm{m}$. After the counting process was completed, the rest of the slide was scanned for rarer diatoms. Several slides contained a limited number of specimens, in this case the whole slide was scanned and the total number of frustules taken into account. Slides with less than 100 specimen counts should be regarded as highly qualitative.

\section{RESULTS}

\section{The fossil microflora at the studied sections}

The Canadian Arctic samples yielded abundant marine diatoms, silicoflagellates, radiolarians, chrysophyte statocysts, and pollen and spores. Diatoms are the dominant group present in these samples and they show compositional changes throughout the sections. Silicoflagellates and chrysophyte statocysts will be the subject of a subsequent paper.

Slidre Fjord section. Only 5 of 29 samples from the measured 260.5m-thick Kanguk Formation contained sufficiently wellpreserved siliceous microfossils for biostratigraphic analysis (text-fig. 4, column A, table 2). Six samples from the lowest $36 \mathrm{~m}$ contained only a few occurrences of pollen and spores. Siliceous microfossils were encountered in the interval $39 \mathrm{~m}$ to 42.5m (samples C-34348, and C-34349). Poor preservation and 
TABLE 3

Selected diatom data (total counts) from Hoodoo Dome Section of both size-fractions (greater and lesser than $25 \mu \mathrm{m}$ ). Preservation: $\mathrm{G}=\mathrm{Good}, \mathrm{M}=\mathrm{Mod}-$ erate, $\mathrm{P}=$ Poor; Relative Abundance: $\mathrm{A}=$ Abundant, $\mathrm{C}=\mathrm{Common}, \mathrm{F}=\mathrm{Few}, \mathrm{R}=$ Rare.

\begin{tabular}{|c|c|c|c|c|c|c|c|c|c|c|c|c|c|}
\hline & \multirow[b]{2}{*}{ 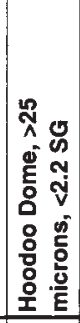 } & \multicolumn{4}{|c|}{ EARLY CAMPANIAN } & \multicolumn{2}{|c|}{$\begin{array}{l}\text { EARLY-LATE } \\
\text { CAMPANIAN }\end{array}$} & \multirow[b]{2}{*}{ 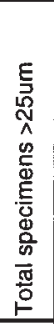 } & \multirow[b]{2}{*}{ 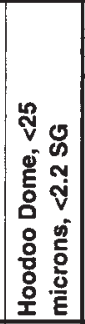 } & \multicolumn{2}{|c|}{$\begin{array}{c}\text { EARLY } \\
\text { CAMPANIAN }\end{array}$} & \multirow[b]{2}{*}{ 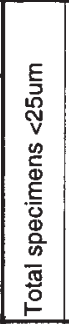 } & \multirow{2}{*}{ 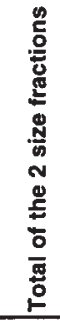 } \\
\hline & & 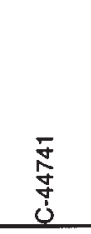 & $\begin{array}{l}\text { ̃ } \\
\text { 导 } \\
\text { d }\end{array}$ & \begin{tabular}{l}
$\frac{3}{4}$ \\
\multirow{+}{*}{} \\
$\dot{J}$
\end{tabular} & 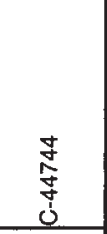 & $\begin{array}{l}\frac{9}{5} \\
\text { 号 } \\
\dot{S}\end{array}$ & $\begin{array}{l}\bar{n} \\
\text { 年 } \\
\dot{5}\end{array}$ & & & $\begin{array}{l}\text { 疋 } \\
\text { 导 } \\
\dot{J}\end{array}$ & $\begin{array}{l}\frac{J}{0} \\
\text { 寸 } \\
\text { d }\end{array}$ & & \\
\hline Outcrop sample interval (m) & & $60-90$ & $90-120$ & $120-150$ & $150-180$ & $300-330$ & $360-390$ & & & $90-120$ & $150-180$ & & \\
\hline Average outcrop elevation (m) & & 75.0 & 105.0 & 135.0 & 169.0 & 315.0 & 375.0 & & & 105.0 & 169.0 & & \\
\hline Preservation & & $\mathbf{P}$ & $P$ & $\mathbf{P}$ & $\mathrm{M}$ & P-M & $M$ & & & P-M & P-M & & \\
\hline Abundance & & $\mathbf{R}$ & $\mathrm{C}$ & $\mathbf{R}$ & $\mathrm{C}$ & $\mathrm{A}$ & $\mathrm{R}$ & & & $\mathrm{F}$ & $\mathbf{R}$ & & \\
\hline Aulacodiscus septus f quatroradiatus & & & & & 2 & & & 2 & & & & 0 & 2 \\
\hline Aulacodiscus septus f. septus & & & & & & 1 & & 1 & & & & 0 & 1 \\
\hline Basilicostephanus sp. 1 & & & 1 & & & & & 1 & & & & 0 & 1 \\
\hline Corinna sp. 1 & & & & & & & & 0 & & 1 & & 1 & 1 \\
\hline Continocornus rossicus & & & & & 17 & & & 17 & & 6 & & 6 & 23 \\
\hline Costopyxis antiqua & & & 28 & 3 & 26 & & 1 & 58 & & & & 0 & 58 \\
\hline Costopyxis ornata & & 3 & & & 10 & 1 & & 14 & & $\mathrm{P}$ & & 0 & 14 \\
\hline Costopyxis shulzii f. shulzii & & 3 & 116 & 8 & 64 & 3 & 2 & 196 & & 17 & 2 & 19 & 215 \\
\hline Costopyxis shulzii var. nuda & & & & & 17 & & 2 & 19 & & 37 & 3 & 40 & 59 \\
\hline Gladiopsis speciosus f. aculeolatus & & & & & & & & 0 & & 4 & & 4 & 4 \\
\hline Gladiopsis speciosus f. speciosus & & & 102 & 8 & 17 & & 2 & 129 & & 1 & & 1 & 130 \\
\hline Hemiaulus altus & & & & & 1 & & & 1 & & 1 & & 1 & 2 \\
\hline Hemiaulus sp. cf. H. polymorphus & & & & & 20 & 2 & 2 & 24 & & 29 & 2 & 31 & 55 \\
\hline Hemiaulus curvatulus & & & & & & & & 0 & & 5 & & 5 & 5 \\
\hline Hemiaulus echinulatus & & & & & 1 & 1 & & 2 & & & & 0 & 2 \\
\hline Hemiaulus kittonni & & & & & & & & 0 & & 2 & & 2 & 2 \\
\hline Hemiaulus polymorphus var. frigida & & & 1 & & 5 & & & 6 & & 7 & & 7 & 13 \\
\hline Hemiaulus schmidti & & & & & 2 & & & 2 & & 5 & & 5 & 7 \\
\hline Hemiaulus sp. A & & & & & 6 & & & 6 & & & & 0 & 6 \\
\hline Hemiaulus sporalis (spores) & & & 1 & & & & & 1 & & $P$ & & 0 & 1 \\
\hline Lepidodiscus elegans & & & 1 & & 1 & & & 2 & & & & 0 & 2 \\
\hline Melosira? campaniensis & & & & & & & & 0 & & 1 & & 1 & 1 \\
\hline Odontotropis cristata & & & & & 4 & & & 4 & & & & 0 & 4 \\
\hline Paralia ornata & & & & & & 2 & & 2 & & 5 & 10 & 15 & 17 \\
\hline Paralia sulcata & & & & & 48 & 7 & 2 & 57 & & 55 & 14 & 69 & 126 \\
\hline Pseudopodosira witti & & & & & 1 & & & 1 & & & & 0 & 1 \\
\hline Stellarima steinyi & & & & & & 2 & & 2 & & & & 0 & 2 \\
\hline Stephanopyxis arctica & & & & & 6 & & & 6 & & & & 0 & 6 \\
\hline Stephanopyxis dissonus & & & & & & & & 0 & & 2 & & 2 & 2 \\
\hline Stephanopyxis grunowi & & & & & 14 & 2 & 2 & 18 & & & & 0 & 18 \\
\hline Thalassiosiropsis wittiana & & & & & 1 & & & 1 & & & & 0 & 1 \\
\hline Triceratium schulzii & & & & & 7 & & & 7 & & 1 & & 1 & 8 \\
\hline Trinacria indefinita & & & & & & 1 & & 1 & & & & 0 & 1 \\
\hline Other diatoms (including resting spores) & & 5 & 19 & 4 & 19 & 5 & 1 & 53 & & 27 & 8 & 35 & 88 \\
\hline TOTAL DIATOMS & & 11 & 269 & 23 & 289 & 27 & 14 & \begin{tabular}{|l|}
633 \\
\end{tabular} & & 206 & 39 & 245 & 878 \\
\hline
\end{tabular}

paucity of diatoms in sample C-34349, however, prevents its inclusion in the final biostratigraphic account. In the interval 42.5 to $62.5 \mathrm{~m}$ only a few spores were observed. A second horizon of siliceous microfossils is present in the interval from 62.5 to $72 \mathrm{~m}$ (samples C-34351 and C-34353). The interval from 82 to $242.5 \mathrm{~m}$ is barren of siliceous microfossils, but some pollen and spores were present. A third interval that contains siliceous microfossils occurs near the top of the section between 252.5 and 254.5m (samples C-34369 and C-34371).
The diatoms Gladius antiquus, Bilingua sp. 1, and Trochosira denticulatum first appear in the sample C-34348 at $39 \mathrm{~m}$ (text-fig. 5, table 2). Basilicostephanus sp. 1 and Actinoptychus heterostrophus were not observed above $72 \mathrm{~m}$. The First Occurrence Datum (FOD) of Costopyxis antiqua is noted in sample C-34351 at $62.5 \mathrm{~m}$, whereas the FOD of Trinacria indefinita is in C-34369 at $252.5 \mathrm{~m}$. Lepidodiscus elegans occurs only in sample C-34353 at $72 \mathrm{~m}$. Common diatom taxa present in this section are Basilicostephanus sp. 1, Costopyxis schulzii f. 
schulzii, Paralia ornata, and P. sulcata. The silicoflagellates Vallacerta hortoni and Vallacerta tumidula are well represented in the Slidre Fjord samples.

Hoodoo Dome section. At this section, 6 out of the 12 samples contained siliceous microflora of sufficiently good preservation for biostratigraphic analysis (text-fig. 4, column B, table 3). The lowest 30m of the measured 390m-thick Kanguk Formation at Hoodoo Dome, contain only scarce spores. An interval of poor to moderate biogenic silica preservation occurs between 60 and $180 \mathrm{~m}$ (samples C-44741 to C-44744). The interval from 180 to $300 \mathrm{~m}$ (samples C-44745 to C-44748) and 330 to $360 \mathrm{~m}$ (sample C-44750) is barren of siliceous microfossils, containing only a few pollen and spore grains. Samples C-44749 (between 300 and 330m) and C-44751 (between 360 and 390m) yielded diatoms, but of poor to moderate preservation.

The diatoms Costopyxis antiqua, Basilicostephanus sp. 1, Triceratium schulzii, and Lepidodiscus elegans are confined to the lower $180 \mathrm{~m}$ (text-fig. 6 , table 3 ). A single occurrence of $C$. antiqua in sample C-44751 (between 360 and 390m) may indicate some reworking or possible contamination. Common diatoms are Costopyxis antiqua, C. schulzii f. schulzii, Gladiopsis speciosus f. speciosus, and Paralia sulcata. Scarce silicoflagellates were noted in the lowest $180 \mathrm{~m}$.

Cape Nares section. At this section, 9 out of 20 samples contained diatoms in a degraded preservation state. All of the slides from the $<25 \mu \mathrm{m}$ size fraction are barren of siliceous microfossils. The Kanguk Formation is $156 \mathrm{~m}$-thick in this region. The lower $66 \mathrm{~m}$ of the Lower Shale Member was barren of siliceous microfossils but contained pollen and spores. A continuous poorly-preserved siliceous microfossil assemblage was noted between 72 and 119m (text-fig. 4, column C; table 4). Samples of sandstone from the Eglinton Member (123 to $144 \mathrm{~m}$ ) were barren or contained rare pollen grains. One sample at $156 \mathrm{~m}$ from the Upper Shale Member contained poorlypreserved and recrystalized diatoms. The siliceous microflora at this section is highly altered and many identifications were possible only to a generic level.

\section{Horton River composite section}

GSC locality CR16A-N68. The siliceous microfossils from this section occur in variable states of preservation. Only 2 out of 20 samples yielded enough material for biostratigraphic analysis (text-fig. 4, column D, tables 5, 6). The Smoking Hills Formation is about $100 \mathrm{~m}$-thick at this location. The lowest $21 \mathrm{~m}$ are barren of siliceous microfossils, but contains scarce pollen and spores. Sample C-8564 (interval from 21.3 to $24.4 \mathrm{~m}$ ) contains siliceous microfossils of moderate preservation. The interval from 24.4 to $97 \mathrm{~m}$ is barren of siliceous microfossils. Sample C-8589 (interval from 97.5 to $100.6 \mathrm{~m}$ ) contains a siliceous microfossil assemblage of moderate preservation. Diatombearing samples were placed at the bottom of the distribution table (text-figures 7, 8; Tables 5, 6) based on field evidence and palynomorph divisions (McIntery 1974).

GSC locality CR16B-N68. A suite of 25 samples contained good to moderately well-preserved siliceous microfossils (text-fig. 4, column D; tables 5, 6) from the 125m-thick Mason River Formation. The Last Occurrence Datum (LOD) of Costopyxis antiqua is observed in sample C-8593 (interval from 9.1 to $12.2 \mathrm{~m}$ ) (text-fig. 8, table 6). Most of the longranging Campanian diatoms are present in the lowest $12 \mathrm{~m}$ of the section. Sample C-8592 (interval from 6.1 to $9.1 \mathrm{~m}$ ) marks the level of the FOD of Sheshukovia sp. 1 (text-fig. 8, table 5). The stratigraphic interval between 15 to $55 \mathrm{~m}$ is dominated by diatom colonial vegetative cells. The FOD of Strelnikovia antiqua occurs in sample C-8596 (interval 18.3 to $21.3 \mathrm{~m}$, table 6), continuing up to sample C-8607 (interval 51.2 to $54.9 \mathrm{~m}$, table 5). Meanwhile, the FOD of the biostratigraphic indicator Stephanopyxis simonseni, is observed at sample C-8608 (interval 54.9 to 57.9 , table 5, text-fig. 7). The interval between 55 to $125 \mathrm{~m}$ contains an increased number of diatom resting spores. Here, the unidentified resting spores \# 3 and \# 4 seem to be potential biostratigraphic markers. The Horton River diatom assemblage is dominated by Aulacodiscus septus, Cortinocornus rossicus, Costopyxis ornata, Goniothecium odontella, Hemiaulus schmidti, $H$. polymorphus var. frigida, $H$. sporalis (spore stage), Meristiosolen sp. 1, Paralia sulcata, Pterotheca aculeifera, spore \# 12, Stellarima stenyi, Stephanopyxis arctica, S. grunowi, S. superba, S. dissonus, S. simonseni, S. turris, Thalassiosiropsis wittiana, Trinacria acutangula, T. indefinita, and Trochosiropsis polychaeta. The silicoflagellates Lyramula furcula and Vallacerta hortoni are among the most conspicuous taxa. Some silicoflagellate taxa attributable to the genus Mesocena (or Bachmanocena) occur rarely in the lower half of this section.

The Horton River Section is the most continuous Upper Cretaceous diatom-bearing section known from North America. Siliceous microfossils are present throughout the section in varying abundance, allowing for the proposal of a diatom biostratigraphy in the northern high-latitudes.

GSC locality CR17A-N68. The 6 samples examined from this section of the Mason River Formation were barren of siliceous microfossils and yielded few pollen and spores.

\section{Diatom biostratigraphy in the Canadian Arctic}

Four diatom biostratigraphic zones are proposed based on the distribution of diatoms in the stratigraphic sections described above (text-fig. 9). The proposed broad zones represent a starting point to aid the application of diatom biostratigraphy to Upper Cretaceous strata. Additional biostratigraphic control from continuous sections recovered in the future is needed to better characterize the zones and eventually subdivide them.

\section{Gladius antiquus Concurrent Range Zone, new zone}

Definition: The stratigraphic interval between the FOD of Basilicostephanus sp. 1 up to the LOD of Gladius antiquus Forti et Schulz. The lower boundary in this section coincides with the lowest diatom-bearing strata and does not represent the total range of this zone. The upper boundary is identified in the Slidre Fjord section 74RV-38, sample C-34348 (39.0m).

Age: Undefined post-Albian to pre-Campanian (Late Cenomanian to Late Santonian?). The age of the G. antiquus Zone is based on a similar age based on mollusks and foraminifera from the lower Kanguk Formation (Jeletzky in Blakwill and Hopkins 1976, Jeletzky in Plauchut and Jutard 1976, Wall 1983, J. H. Wall, pers. comm.).

Associated species: Basilicostephanus sp. 1, Bilingua sp. 1, Corinna sp. 1, Costopyxis ornata (Schulz) Strelnikova, C. schulzii (Steinecke) Gleser, C. schulzii var. nuda Strelnikova, Gladiopsis speciosus f. aculeolatus Strelnikova, G. speciosus f. speciosus (Schulz) Strelnikova, Hemiaulus sp. A, H. antiquus Jousé, $H$. echinulatus Jousé, $H$. polymorphus var. frigida Grunow, H. schmidti Hajós, Hemiaulus sp. 1, Hyalodiscus sp. 2, 


\section{HOODOO DOME, Combined data}

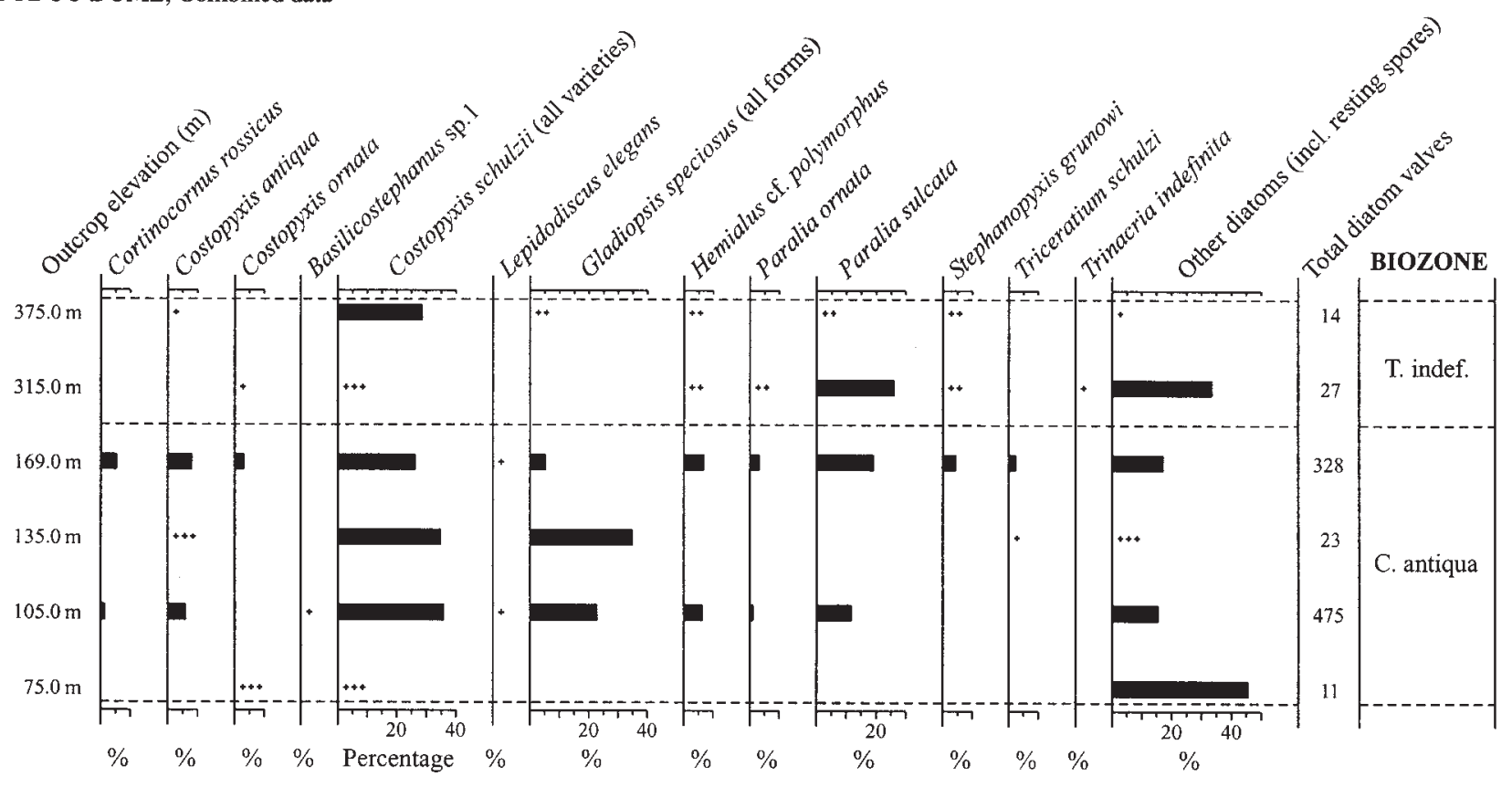

TEXT-FIGURE 6

Diatom stratigraphy of selected diatom taxa in the Hoodoo Dome section. Relative abundances (percentage) of taxa were calculated after the combined data (sum of greater and lesser than 25 micrometer fractions). Crosses indicate rare occurrences (usually <1\%).

Micrampula parva Hanna, Paralia ornata (Grunow) Grunow ex van Heurck, P. sulcata (Ehrenberg) Cleve, Porpeia sp. 2, Pseudopyxilla sp. cf. P. rossica (Pantocsek) Forti, Stellarima stenyi (Hanna) Hasle et Sims, Stephanopyxis grunowi Grove et Sturt, S. sp. A, Trochosira denticulatum (Strelnikova) Tapia, and Trochosiropsis polychaeta (Strelnikova) Tapia.

Reference section: Slidre Fjord, Ellesmere Island, District of Franklin, Canada. GSC locality 74RV-38, sample C-34348, at approximately $39.0 \mathrm{~m}$ from the base of the section.

Comments: The Gladius antiquus Zone is, at present, a poorly documented biostratigraphical zone. It is differentiated from the overlying Costopyxis antiqua Zone by the presence of $G$. antiquus Forti et Schulz and Bilingua sp. 1. The stratigraphic level of the lower boundary is poorly defined and may range to the lower part of the Upper Cretaceous. As this zone is based on the occurrence of G. antiquus in only one sample, more reliable samples are needed to better define the zonal boundaries. The genera Basilicostephanus Gersonde et Harwood, Bilingua Gersonde et Harwood and Gladius Forti et Schulz are widely represented in the Lower Cretaceous (Harwood and Nikolaev 1995) and are well-known in the Aptian-Albian sediments of Antarctica (Gersonde and Harwood 1990). This zone is, however, not likely to be Lower Cretaceous due to the absence of many Lower Cretaceous taxa and the presence of Upper Cretaceous diatoms (Costopyxis Gleser, Gladiopsis Gersonde et Harwood, Hemiaulus sensu lato, Stellarima Hasle et Sims, and Stephanopyxis Ehrenberg). The rare occurrence of Lower Cretaceous forms (Basilicostephanus, Bilingua, and Gladius) indicates a transitional interval including the last survivors from a previous diatom radiation (Harwood and Nikolaev 1995).

\section{Costopyxis antiqua Partial Range Zone, new zone}

Definition: The stratigraphic interval between the LOD of Gladius antiquus Forti et Schulz up to the LOD of Costopyxis antiqua (Jousé) Gleser. The lower boundary is identified in the Slidre Fjord section 74RV-38, sample C-34351 (62.5m), and the upper boundary is identified at the Horton River section CR16B-N68, sample C-8593 (9.1-12.2m).

Age: Early Campanian, based on diatom biostratigraphic correlation to the First Diatom Complex (Early Campanian) of Strelnikova (1974). The lower boundary may be slightly older problably into the Late Santonian.

Associated species: Actinodiscus sp. 2, Actinoptychus heterostrophus Schmidt, Basilicostephanus sp. 1, Costopyxis ornata (Schulz) Strelnikova, C. schulzii (Steinecke) Gleser, Lepidodiscus elegans Witt, Paralia ornata (Grunow) Grunow ex van Heurck, and Triceratium schulzii Jousé.

Reference sections: Lower part of the C. antiqua Zone: Slidre Fjord section, 74RV-38, samples C-34351 and C-34353 (section interval from 62.5 to $72.0 \mathrm{~m}$ ). Upper part of the $C$. antiqua Zone: Horton River section, locality CR16A-N68, samples C-8564 (21.3-24.4m), and C-8589 (97.5-100.6m); locality CR16B-N68, samples C-8590 (0.0-3.0m) to C-8593 (9.1-12.2m).

Comments: The $C$. antiqua Zone is not fully represented in a single section. In order to establish this biostratigraphic zone, it was necessary to combine intervals from the Slidre Fjord and Horton River sections. 


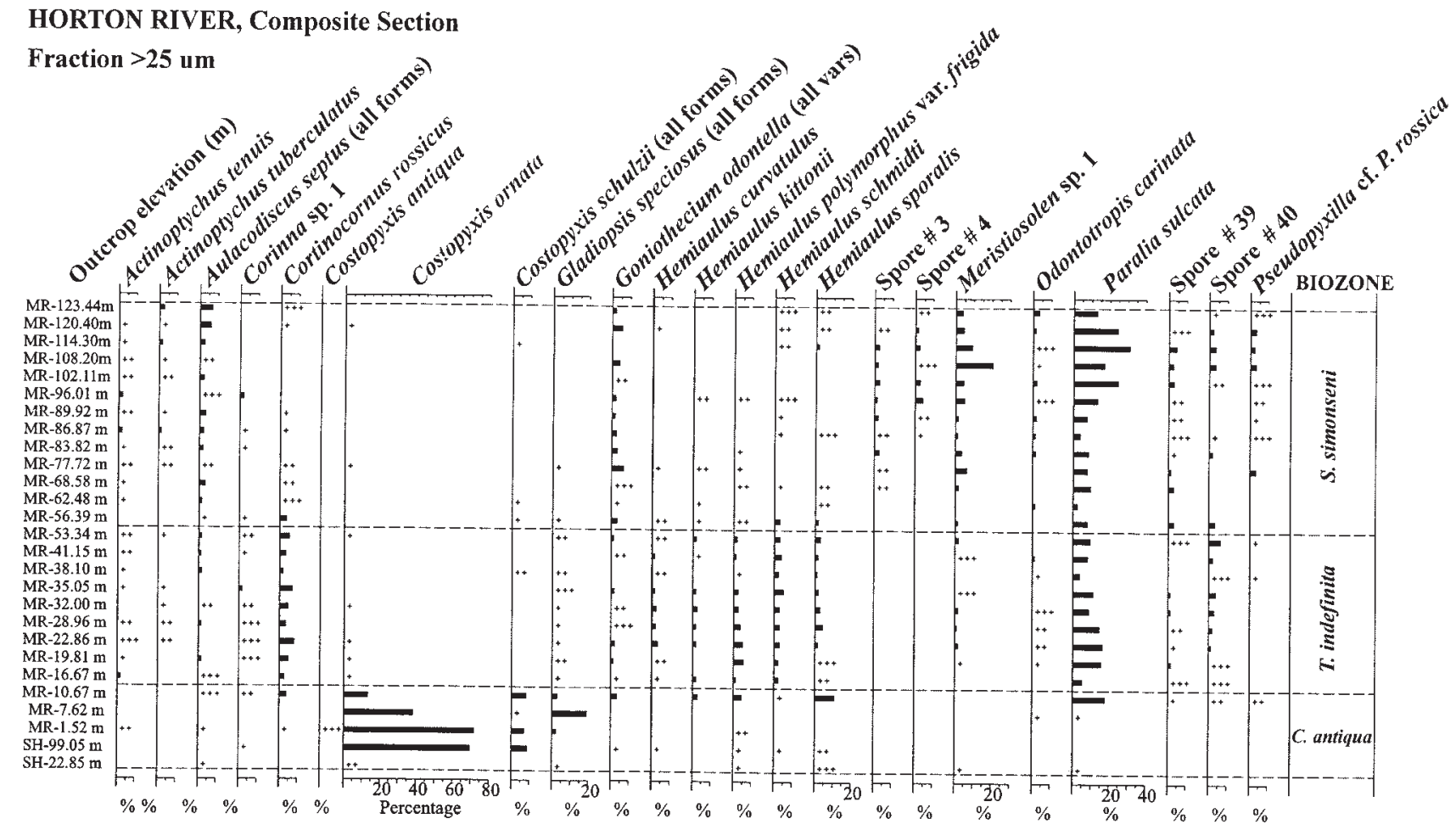

TEXT-FIGURE 7

Diatom stratigraphy in the Horton River composite section. Relative abundance (percentage) of selected diatom taxa in the fraction greater than 25 micrometers. Dots indicate rare occurrences $(<1 \%)$. MR = Mason River Fm.; SH = Smoking Hills Fm.

\section{Trinacria indefinita Interval Zone, new zone}

Definition: The stratigraphic interval from the LOD of Costopyxis antiqua (Jousé) Gleser, up to the FOD of Stephanopyxis simonseni Hajós. The lower boundary is identified in the Horton River section CR16B-N68, sample C-8595 (15.2-18.3m), and the upper boundary is identified in the same section, sample C-8607 (51.2-54.9m).

Age: Early Late Campanian, based on diatom biostratigraphic correlation to the Second Diatom Complex (early Late Campanian) of Strelnikova (1974).

Associated species: This zone includes the long-ranging Upper Campanian assemblage including diatoms Actinoptychus tenuis Strelnikova, A. tuberculatus Strelnikova, Aulacodiscus septus Schmidt, Cortinocornus rossicus (Pantocsek) Gleser, Goniothecium odontellum Ehrenberg, Hemiaulus polymorphus var. frigida Grunow, H. schmidti Hajós, H. sporalis Strelnikova (spore stage), Odontotropis carinata Grunow, Paralia sulcata (Ehrenberg) Cleve, Pterotheca aculeifera Grunow, Stellarima stenyi (Hanna) Hasle et Sims, Stephanopyxis arctica (Grunow) Strelnikova et Nikolaev, S. dissonus (Schulz) Strelnikova et Nikolaev, S. grunowi Grunow et Sturt, S. turris Greville et Arnott, Thalassiosiropsis wittiana (Pantocsek) Hasle, and Trinacria acutangula (Strelnikova) Barron. Characteristic diatoms from this zone are Sheshukovia sp. 1, Stephanopyxis superba (Greville) Grunow, Strelnikovia antiqua (Strelnikova) Ross et Sims, and Trinacria indefinita Jousé.

Reference section: Horton River section locality CR16B-N68, samples C-8595 (15.2-18.3m) to C-8607 (51.2-54.9m).
Comments: The occurrence of the peculiar taxon Strelnikovia antiqua (Strelnikova) Ross et Sims is observed along the interval of the $T$. indefinita Zone, although the low abundance of $S$. antiqua excludes naming this zone after this diatom.

\section{Stephanopyxis simonseni Partial Range Zone, new zone}

Definition: The stratigraphic interval from the FOD of Stephanopyxis simonseni Hajós up to the FOD of Azpeitiopsis morenoensis (Hanna) Sims. The lower boundary is identified at the Horton River section CR16B-N68, sample C-8608 (54.9$57.9 \mathrm{~m})$. The upper boundary was not identified in this section.

Age: Late Late Campanian, based on diatom biostratigraphic correlation to the Third Diatom Complex (late Late Campanian) of Strelnikova (1974).

Associated species: The diatom assemblage in this zone includes the long-ranging Upper Campanian assemblage (see above) and the presence of the unidentified resting spores \#3 and \# 4, Trinacria sp. 3, Biddulphia sp. 6, Trochosiropsis polychaeta (Strelnikova) Tapia, Pterotheca sp. cf. P. spada Tempère et Brun, and resting spore \#12.

Reference section: Horton River section locality CR16B-N68, samples C-8608 (54.9-57.9m) to C-8630 (121.9-125.0m).

Comments: The upper boundary of the Stephanopyxis simonseni Zone is here defined as the FOD of Azpeitiopsis morenoensis (Hanna) Sims. A. morenoensis does not occur in the Arctic samples, although is a common element of Maastrichtian diatom as- 


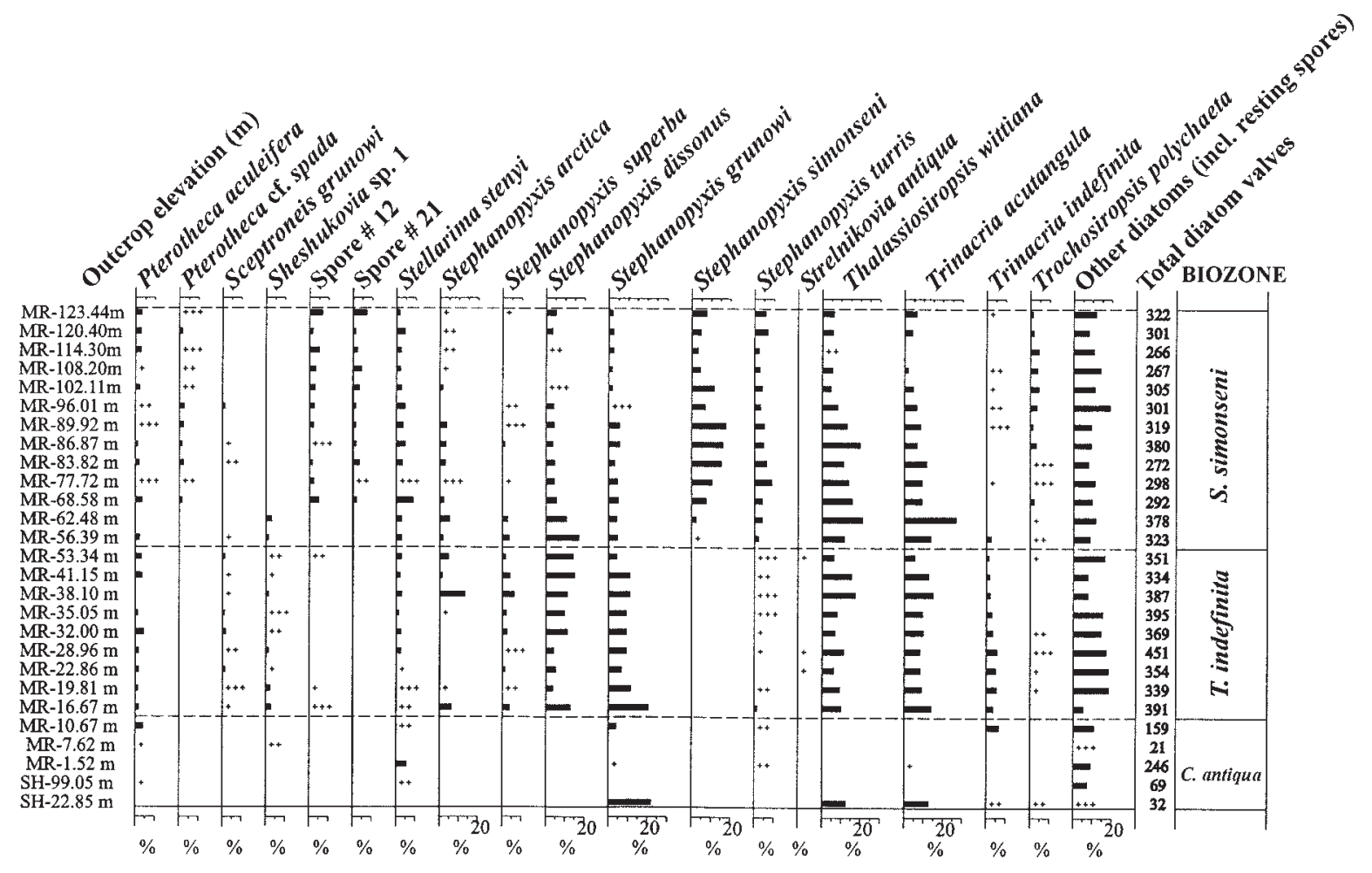

TEXT-FIGURE 7

Continued.

semblages around the world (Sims 1994a, Nikolaev and Harwood 2000).

Global records of Maastrichtian diatom-bearing sediments indicate that another diatom biostratigraphic zone outside the Canadian Arctic region can also be proposed.

\section{Azpeitiopsis morenoensis Concurrent Zone, new zone}

Definition: The stratigraphic interval from the FOD of Azpeitiopsis morenoensis (Hanna) Sims up to the LOD of Gladiopsis speciosus (Schulz) Gersonde et Harwood sensu lato.

Age: Early to Late Maastrichtian. Correlative to the Maastrichtian Diatom Complex of Strelnikova (1975).

Associated species: Extensive flora described in Hanna (1927, 1934), Long et al. (1946), Barker and Meakin (1944, 1945, 1946, 1948, 1949), Brigger and Hanna (1965), Hasle and Syvertsen (1985), Nikolaev et al. (2001), Ross and Sims (1985, 1997), Sims and Hasle (1987), Sims and Ross (1988), and Sims (1986, 1989, 1994a,b) for the Moreno Formation of California.

Reference section: Not identified. There are accounts of well-dated Lower Maastrichtian diatoms in the Raggatt Basin, ODP Hole 748C, Kerguelen Plateau, Southern Ocean (Nikolaev and Harwood 2000), and the intensively studied Upper Maastrichtian Moreno Formation, Moreno Gulch, Fresno County, California, USA (see references above).

Comments: This zone is proposed in view of the global distribution of Azpeitiopsis morenoensis (Hanna) Sims. The lower boundary of this zone may appear in the stratigraphic record between the uppermost Campanian and the lowermost Maas- trichtian. This is inferred because the uppermost Campanian section is missing in the Mason River Fm., Arctic Canada, but it appears to be recovered in the Lower Maastrichtian sediments of ODP Site 748, Raggatt Basin, Kerguelen Plateau (Nikolaev, pers. comm.). The upper boundary defined as the LOD of $G$. speciosus (sensu lato) occurs in the Upper Maastrichtian Lopez de Bertodano Fm. on Seymour Island, Antarctic Peninsula (Harwood 1988).

\section{DISCUSSION}

Before the present study, only two diatom biostratigraphic zonal schemes were proposed for the Upper Cretaceous. The northern high-latitude (Russia) diatom complexes and the southern high-latitude (Campbell Plateau, SW Pacific) diatom biostratigraphic zones. The new Arctic Upper Cretaceous diatom biostratigraphy is in general agreement with biostratigraphical divisions based on three diatom assemblage zones from the Ural Mountains, Russia (Strelnikova 1974, 1975; text-fig. 3-A). The Costopyxis antiqua Zone is correlated tentatively with the First Diatom Complex (Early Campanian) (Strelnikova 1974), based on the occurrence of Costopyxis antiqua (Jousé) Gleser, Lepidodiscus elegans Witt, Paralia ornata (Grunow) Grunow ex van Heurck, Triceratium schulzii Jousé, and Hemiaulus echinulatus Jousé. The Trinacria indefinita Zone is correlated tentatively with Strelnikova's (1974) Second Diatom Complex (early Late Campanian) based on the presence of Stephanopyxis turris (Greville et Arnott) Ralfs, Paralia sulcata (Ehrenberg) Cleve, Trochosiropsis polychaeta (Strelnikova) Tapia, Hemiaulus antiquus Jousé, $H$. kittonii Grunow, Gladiopsis speciosus f. speciosus (Schulz) Strelnikova, and Pterotheca aculeifera Grunow. The Stephanopyxis simonseni Zone is tentatively correlated to the Third 


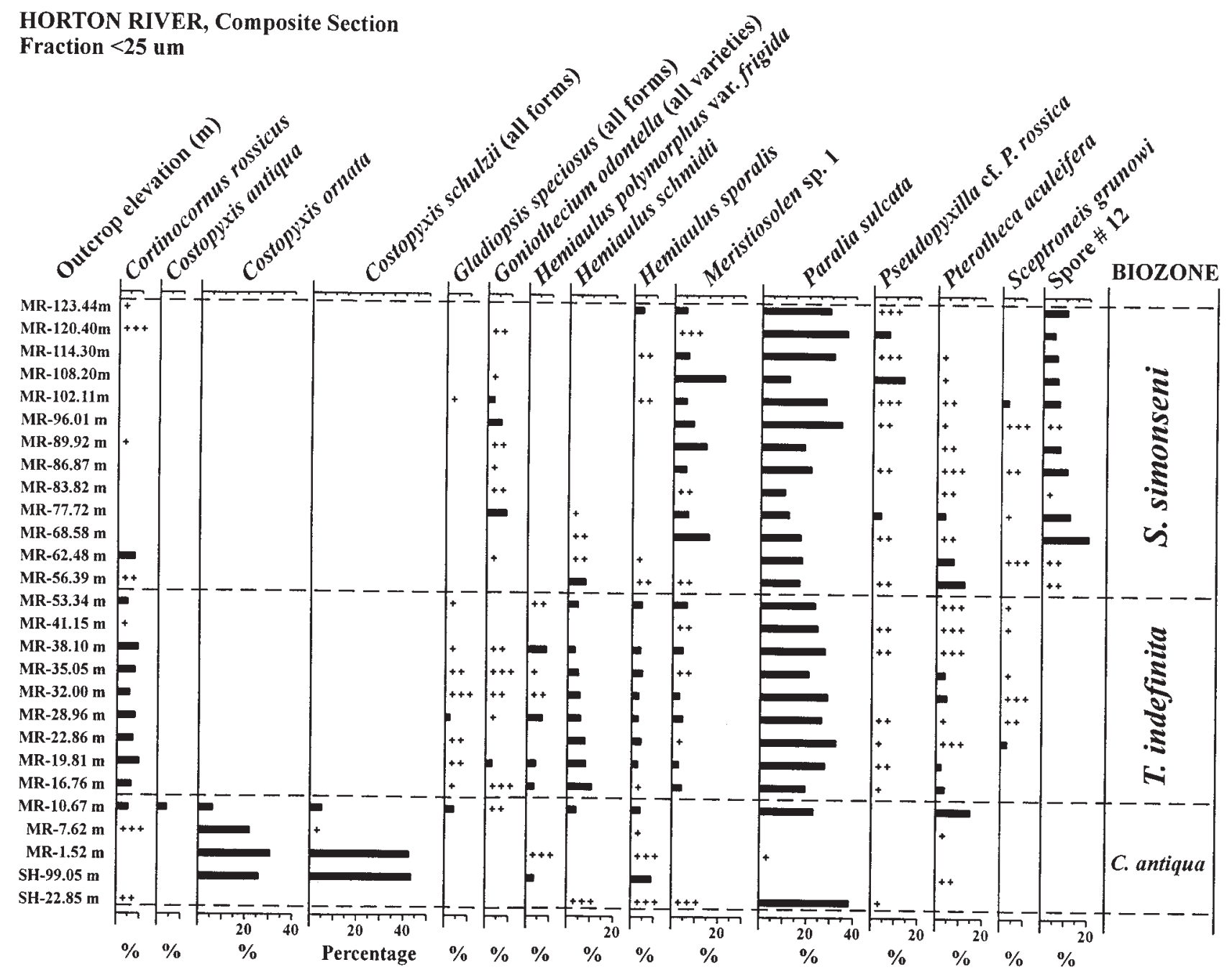

TEXT-FIGURE 8

Diatom stratigraphy in the Horton River composite section. Relative abundance (percentage) of selected diatom taxa in the fraction lesser than 25 micrometers. Crosses indicate rare occurrences $(<1 \%)$. MR = Mason River Fm.; SH = Smoking Hills Fm.

Diatom Complex (late Late Campanian) (Strelnikova 1974), based on the co-occurrence of Costopyxis reticulata (Long, Fuge et Smith) Gleser, Paralia sulcata (Ehrenberg) Cleve, Pseudopyxilla sp. cf. P. rossica (Pantocsek) Forti and Stephanopyxis turris (Greville et Arnott) Ralfs. No correlation can be made with the oldest zone, the Gladius antiquus Zone, as it is known only from the Sverdrup Basin (this study). Diatoms analyzed from Alpha Ridge, Arctic Ocean Basin, (Barron 1985, Dell'Agnese 1988, Dell'Agnese and Clark 1994) bear close resemblance to the Upper Campanian Trinacria indefinita and Stephanopyxis simonseni zones.

The Upper Campanian diatom record is the best known interval of the Upper Cretaceous, either from low latitudes (Ninety-east Ridge), southern-intermediate latitudes (Tonga Trench), and southern high-latitudes (Campbell Plateau) with many taxa in common. The nine biostratigraphic zones from Campbell Plateau core sediments (Hajós and Stradner 1975; text-fig. 3B) cannot be compared directly with the Canadian Arctic zonation, because key taxa do not occur in the Arctic sediments.

As evident in the Canadian samples, the state of silica preservation plays an important role in determining the presence of siliceous microfossils at the different subsample fractions. As a general rule, the presence of moderate to well-preserved microfossils at the $>25 \mu \mathrm{m}$ fraction will guarantee the presence of small siliceous microfossils at the $<25 \mu \mathrm{m}$ fraction. Similarly, poorly preserved siliceous microfossils in the greater subsample are associated with barren preparations in the finer subsample.

Moreover, the presence of other microfossil groups in the same samples allowed a microfossil correlation throughout the sections. At Slidre Fjord, diatoms are better biostratigraphic indicators than their foraminiferal counterparts. The diatom zones $(G$. antiquus, C. antiqua, and T. indefinita) span three different time periods (Cenomanian-Santonian, Early Campanian, early Late 


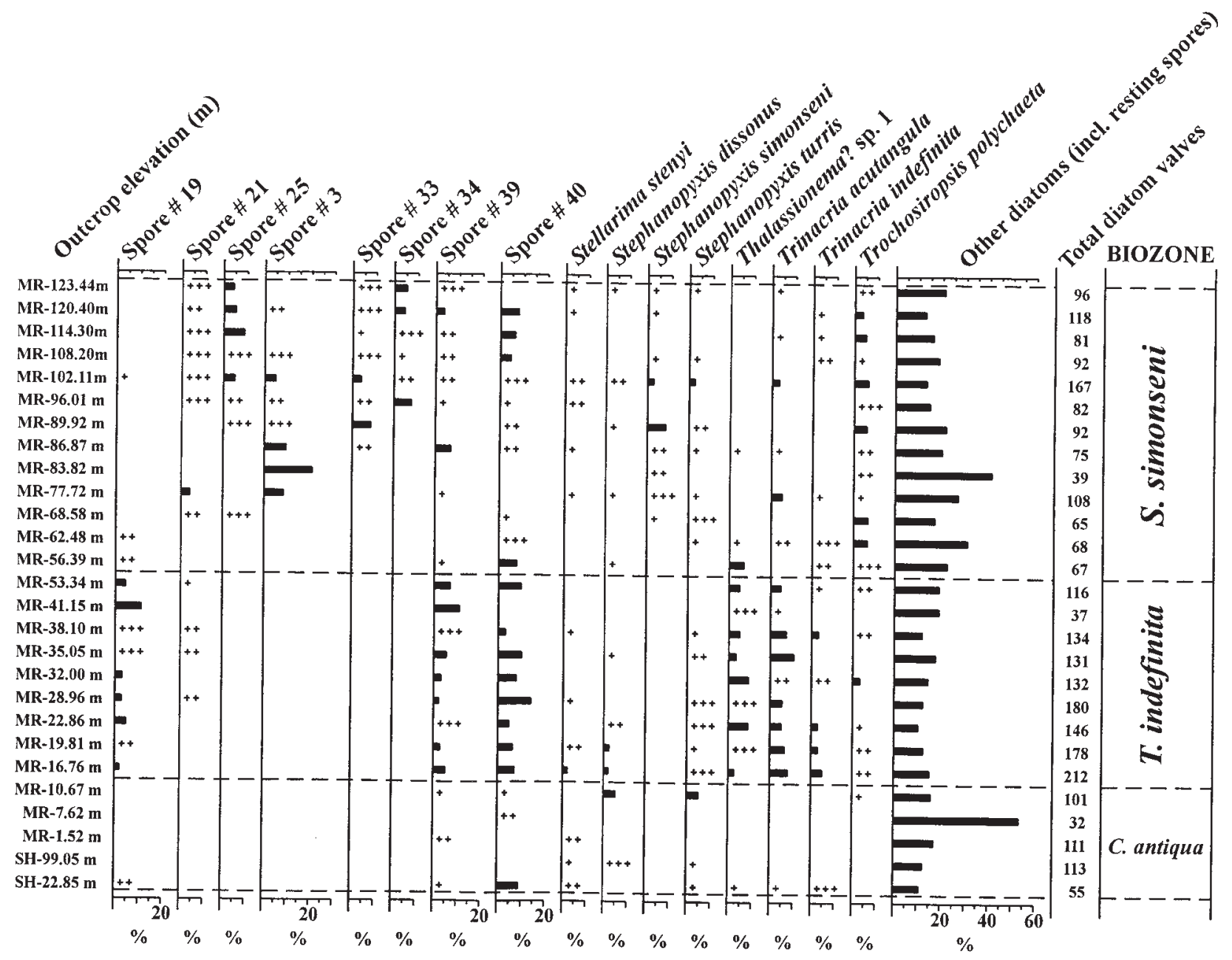

TEXT-FIGURE 8

Continued.

Campanian) and coincide with an undifferentiated Campanian foraminiferal assemblage (J. H. Wall, pers. comm.).

Currently, it is not possible to correlate the diatom biostratigraphic record from Hoodoo Dome to other microfossil zonations. The diatom record is not completely clear in Hoodoo Dome to discern whether it represents 1 or 2 biostratigraphic zones. The single occurrence of $C$. antiqua in the upper section may be a reworked element, thus we think that both $C$. antiqua and $T$. indefinita zones are present in this section.

The diatom record at Cape Nares is highly altered by diagenetic processes. Foraminiferal data indicate an age range from Late Turonian to Early Campanian due to the presence of taxa from the Dorotia smokyensis Zone (J. H. Wall, pers. comm.). The diatoms indicate an undifferentiated Campanian age, although Early Campanian may be suggested due to the presence of some partially recognizable specimens of $C$. antiqua and $P$. ornata.

A microfossil correlation is better achieved with samples from the composite Horton River section. The palynological divisions reported from this section (McIntyre 1974) agree with the diatom data. Microfloral divisions 1 and 2 correspond with the
Early Campanian $C$. antiqua Zone. The Upper Campanian diatom zones, are equivalent to the lower two-thirds of McIntyre's division 3. Following McIntyre's zonation, the boundary between the Campanian-Maastrichtian corresponds approximately to the boundary between the $T$. indefinita and $S$. simonseni diatom zones.

A correlation between the Upper Cretaceous sediments from the Anderson Plains and the Sverdrup Basin was proposed based on palynological data (Yorath et al. 1975, Plauchut and Jutard 1976). The Smoking Hills Formation was correlated with the lower Kanguk Formation, whereas the Mason River Formation with the upper Kanguk Formation. The diatom record indicates a partial correlation among those formations (text-fig. 9). The Kanguk Formation in the Sverdrup Basin -e.g. Slidre Fjord Section- has a much older record (G. antiquus Zone) in comparison to the sediments at the continental margin. Moreover, it correlates to the Smoking Hills Formation (C. antiqua Zone) and partially to the Mason River Formation ( $T$. indefinita Zone) of the Anderson Plain Syncline. No evidence of the upper Mason River Formation equivalent ( $S$. simonseni Zone) was identified in samples of the Kanguk Fm. 
TABLE 4

Diatom data (total counts) from Cape Nares Section of the fraction greater than $25 \mu \mathrm{m}$. Preservation: $\mathrm{G}=\mathrm{Good}, \mathrm{M}=$ Moderate, $\mathrm{P}=$ Poor; Relative Abundance: $\mathrm{A}=$ Abundant, $\mathrm{C}=\mathrm{Common}, \mathrm{F}=\mathrm{Few}, \mathrm{R}=$ Rare.

\begin{tabular}{|c|c|c|c|c|c|c|c|c|c|c|}
\hline & \multicolumn{9}{|c|}{ Campanian } & \multirow{2}{*}{ 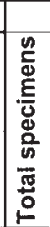 } \\
\hline & $\begin{array}{l}R \\
8 \\
0 \\
0 \\
0 \\
0 \\
0\end{array}$ & $\begin{array}{l}\overline{1} \\
8 \\
6 \\
0 \\
0 \\
0\end{array}$ & $\begin{array}{l}8 \\
8 \\
0 \\
10 \\
\vdots \\
0\end{array}$ & $\begin{array}{l}9 \\
8 \\
8 \\
6 \\
5 \\
\\
\end{array}$ & $\begin{array}{l}9 \\
8 \\
8 \\
10 \\
\frac{10}{0}\end{array}$ & 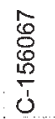 & $\begin{array}{l}\mathscr{8} \\
\mathscr{8} \\
8 \\
\\
\\
\end{array}$ & $\begin{array}{l}1 \\
0 \\
0 \\
0 \\
10 \\
\dot{10} \\
\dot{0}\end{array}$ & $\mid \begin{array}{l}8 \\
0 \\
0 \\
10 \\
10\end{array}$ & \\
\hline Outcrop elevation (m) & 156 & 119 & 113 & 102 & 96 & 90 & 84 & 78 & 72 & \\
\hline Preservation & $P$ & $P$ & $\mathrm{P}$ & $\mathrm{P}$ & $\mathrm{P}$ & $P$ & $P$ & $P$ & $P$ & \\
\hline Abundance & $\mathrm{R}$ & $\mathrm{R}$ & $\mathrm{R}$ & $\mathrm{R}$ & $\mathrm{R}$ & $\mathrm{F}-\mathrm{C}$ & $\mathrm{F}$ & $\mathrm{R}$ & $\mathrm{R}$ & \\
\hline Coscinodiscus sp. & & & & & 2 & & & & & 2 \\
\hline Costopyxis spp. & 17 & 20 & 10 & 47 & 97 & 145 & 91 & 7 & 7 & 441 \\
\hline Gladiopsis sp. & 2 & & 5 & 11 & 15 & 17 & 9 & 2 & 3 & 64 \\
\hline Gonothecium odontella & & & & 4 & 9 & & 5 & 1 & 1 & 20 \\
\hline Hemiaulus spp. & 3 & & & 12 & 26 & 39 & 52 & 4 & & 136 \\
\hline Odontotropis sp. & & & & & & & 1 & & & 1 \\
\hline Paralia sp. & & & 1 & & & 1 & & & 2 & 4 \\
\hline Pseudopyxilla sp. & & & & 2 & & 1 & & & & 3 \\
\hline Pterotheca sp. & & & & & & 1 & & & & 1 \\
\hline Stephanopyxis sp. & 1 & 5 & & 1 & & 10 & & & & 17 \\
\hline Triceratium sp. & & & & 1 & & 2 & 5 & & 2 & 10 \\
\hline Trinacria sp. & & & & & & & & 1 & & 1 \\
\hline Total diatoms & 23 & 25 & 16 & 78 & 149 & 216 & 163 & 15 & 15 & 700 \\
\hline
\end{tabular}

The present diatom biostratigraphic study from the Canadian Arctic permitted the construction of a new northern highlatitude biostratigraphy framework based upon four biostratigraphic zones. The Azpeitiopsis morenoensis Zone is proposed in light of the worldwide occurence of this taxon ranging from deposits of California (Hanna 1927, Long et al. 1946), Akupa River basin, Koryak Range, Russia (Strelnikova 1975), Tonga Trench, South Pacific (Nikolaev, pers. comm. 1996), and Kerguelen Plateau, Southern Ocean (Nikolaev, pers. comm., 1996). Figured specimens from Seymour Island, Campbell Plateau, and Ninety-east Ridge are possible misidentifications (Nikolaev, pers. comm. 1996). The samples at Kerguelen Plateau (ODP Leg 120, Site 748, Raggatt Basin) bear a special flora including $A$. morenoensis and several species of Pomphodiscus (Nikolaev and Harwood 2000). Biostratigraphic control in the best productive sample (748C, 48R-01, 4-6cm) is based on calcareous nannoplankton; cores 40R to 48R are restricted to the Last Appearance Datum (LAD) of Aspidolithus parcus and the LAD of Eiffellithus eximius, narrowing the depositional time to an Early Maastrichtian age (Watkins et al. 1992). At the present, this is the only well-dated, diatomaceous-bearing sample for the Lower Maastrichtian in the world. At Kerguelen Plateau, A. morenoensis is not as abundant as it is in Upper Maastrichtian Moreno Formation sediments from California. As defined, the top of A. morenoensis Zone is marked by the LOD of Gladiopsis speciosus (sensu lato) a species that radiates in the Upper Cretaceous and appears to die out at the end of the Cretaceous (Late Maastrichtian) (Harwood and Nikolaev 1995). An example of the extinction of G. speciosus is given in the Upper Maastrichtian Lopez de Bertodano Formation on Seymour Island, Antarctic Peninsula (Harwood 1988) where the genus Gladiopsis does not continue across the K/T boundary.

\section{CONCLUSIONS}

The results of 49 samples containing sufficiently preserved diatoms from a composite stratigraphic section of $1094 \mathrm{~m}$ of the Kanguk, Mason River and Smoking Hills formations in the Canadian Arctic provide biostratigraphic data to enable the con- struction of a northern high-latitude Campanian diatom biostratigraphic zonation.

A high siliceous microfossil diversity was encountered. The microfossil assemblages comprise 203 diatom taxa, 20 silicoflagellate taxa, and 16 chrysophyte statocyst taxa.

Four diatom biostratigraphic zones are proposed for the Canadian Arctic. In ascending order they are: (1) The Upper Cenomanian to Upper Santonian(?) Gladius antiquus Concurrent Range Zone; (2) the Lower Campanian Costopyxis antiqua Partial Range Zone, (3) the lower Upper Campanian Trinacria indefinita Interval Zone; and (4) the upper Upper Campanian Stephanopyxis simonseni Partial Range Zone. A fifth diatom biostratigraphic zone, the Maastrichtian Azpeitiopsis morenoensis Concurrent Range Zone, is proposed based on stratigraphic information from other sites around the globe.

Founded on the proposed diatom biostratigraphic zones, we attempt the following diatom-based correlation among Upper Cretaceous lithostratigraphic units in the Canadian continental margin and Sverdrup Basin. The Kanguk Formation is correlated in part with the lower Mason River and Smoking Hills formations ( $C$. antiqua and $T$. indefinita zones). The younger $S$. simonseni Zone is not present in other samples than from the upper part of the lower Mason River Formation. The oldest zone, the G. antiquus zone, is restricted to the lowermost Kanguk Formation interval examined here.

\section{ACKNOWLEDGMENTS}

This contribution comprises a portion of the Master's Thesis by P. M. Tapia completed at the University of Nebraska at Lincoln (UNL). Financial support was provided by the National Science Foundation grant OPP-9158075 to D. M. Harwood, Geological Society of America Grant-in-Aid to P. M. Tapia, UNL's Research Council, donations from UNL-Geosciences alumni, and the Lincoln Gem and Mineral Club. The manuscript was critically reviewed by D. K. Watkins, K. Reinhard, V. Nikolaev, and J. Barron and further improved with constructive observations from J. Fenner and P. Sims. Special thanks to D. McNeil (GSC) who furnished the Canadian Arctic Cretaceous samples. Technical assistance was provided by S. Rose, D. Winter, and A. Srivastav.

\section{APPENDIX 1}

Diatom taxonomic list. The following list comprises most of the diatom species identified during the present work and listed on tables 2 to 6 . Many unknown forms are placed in uncertain generic categories. This clearly indicates that proper taxonomic studies are required for many taxa. Refer to Tapia (1996) for a complete list of diatom encountered in this study.

Actinodyction weissflogii Pantocsek 1892: Bd. 3, Tab. 5, fig. 84; Strelnikova 1974: 72, Tab. 18, figs. 2-6.

Actinoptychus heterostrophus Schmidt in Schmidt et al. 1875-1959: Tab. 29, fig 2, Tab. 109, figs. 9-11; Witt 1886:152, Tab. 8, fig. 1; Jousé et al. 1949: Vol. 2, p. 97 , Tab. 40, fig. 12; Strelnikova 1974: 69, Tab. 14, fig. 8.

Actinoptychus simbriskianus Schmidt in Schmidt et al. 1875-1959: Tab. 29, fig. 11; Tab 109, figs. 3-9; Barron 1985: Pl. 10.1, fig. 8; Dell'Agnese and Clark 1994: 38, fig. 3.1. [Plate III, figs. 9-10]

Actinoptychus tenuis Strelnikova 1974: 67, Tab. 14, figs. 1-4; Barron 1985: 141, Pl. 10.1, fig. 7; Dell'Agnese and Clark 1994: 38, figs. 3.2. [Plate VII, fig. 1] 


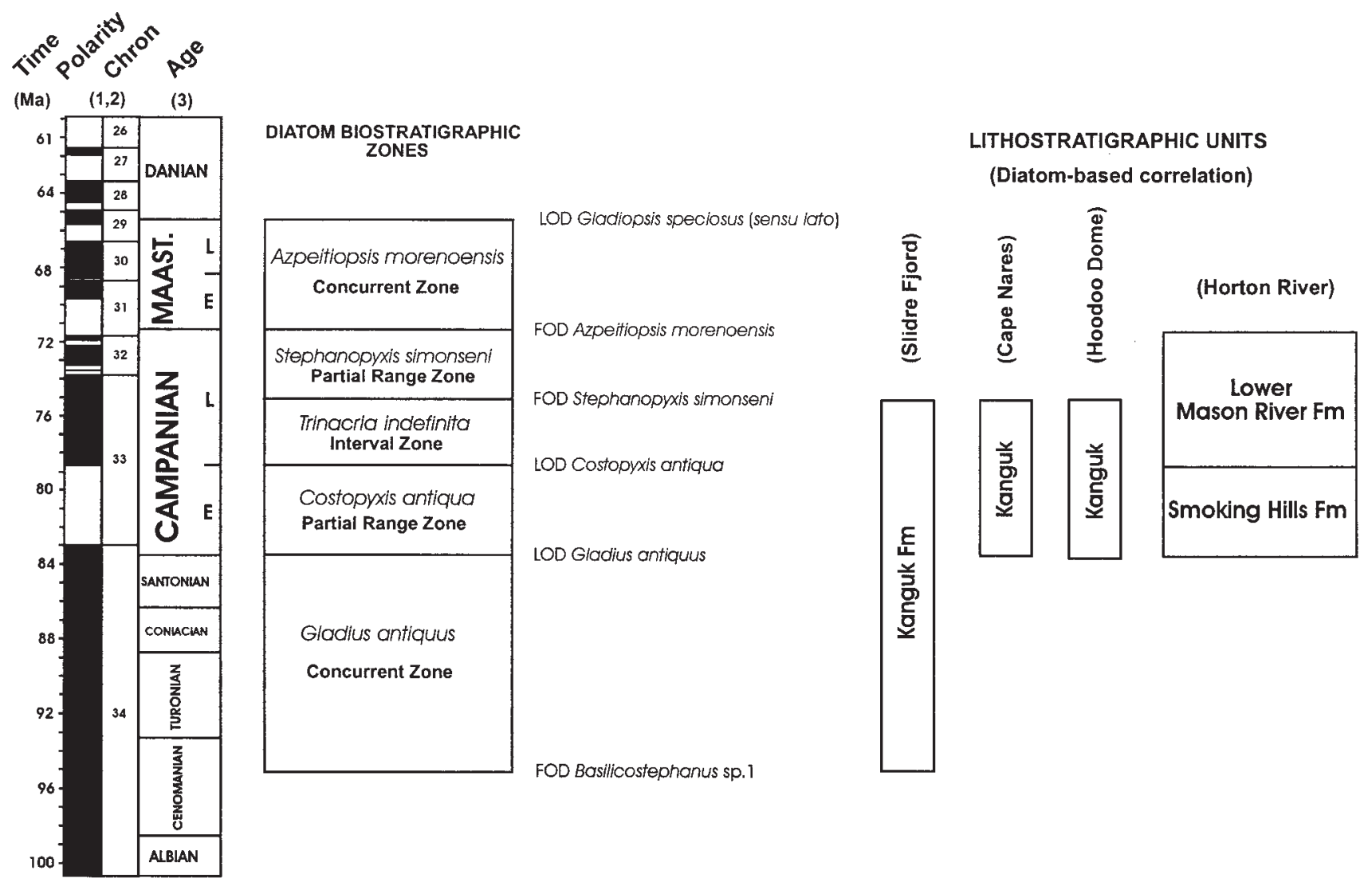

\section{TEXT-FIGURE 9}

Proposed Upper Cretaceous diatom zonation for Arctic Canada and correlation of lithostratigraphic units in Arctic Canada. The diatom biostratigraphic zones are referenced against Cretaceous geochronology (1), Geomagnetic Polarity time scale (2), and Cretaceous ages (3). 1= Kent and Gradstein (1995); $2=$ Cande and Kent (1992); 3= Obradovich (1993). Correlation among lithostratigraphic units is based only in diatom-bearing intervals within each studied sections.

Actinoptychus tuberculatus Strelnikova 1974: 68, Tab. 14, figs. 5, 6. [Plate VII, fig. 4]

Anaulus sp. cf. A. sibiricus Strelnikova 1974: 106, Tab. 52, figs. 1-5; Anaulus sibericus Strelnikova sensu Barron 1985: 141, Pl. 10.2, fig. 10; Harwood 1988: 79: figs. 9.12-14; Dell' Agnese and Clark 1994: 38, fig. 3.3 Aulacodiscus breviprocessus Strelnikova 1974: 76, Tab. 25, figs. 1-4; Harwood 1988: 79: fig. 12.3.

Aulacodiscus septus forma quattuorradiata Pantocsek 1886: Bd. I, p. 62, Tab. 10, fig. 84; Strelnikova 1974: 73-74, Tab. 20, fig. 6; Aulacodiscus septus forma tetragonus Jousé 1949: 70.

Aulacodiscus septus forma septus (Schmidt) Strelnikova; Aulacodiscus septus Schmidt in Schmidt et al. 1875-1959: Tab. 36, figs. 19-21; Schulz 1935: 387, Tab. 2, fig. 4; Jousé 1949: 70, Tab. 1, fig, 11; Jousé et al. 1949: Vol. 2, p. 107, Tab. 37, fig. 1; Strelnikova 1965b: 32, Tab. 2, figs. 1-3; Aulacodiscus septus Schmidt forma septus Strelnikova 1974: 73, Tab. 19, figs. 1-6, Tab. 20, figs. 1-5. [Plate VII, fig. 3]

Basilicostephanus sp. 1. [Plate I, figs. 7, 8; Plate II, figs. 2-4] Biddulphia grunowi Pantocsek 1892: Bd. 3, Taf. 24, fig. 366.

Bilingua sp. 1. [Plate I, figs. 9, 10]

Corinna sp. 1. [Plate IX, figs. 11, 12]

Cortinocornus rossicus (Pantocsek) Gleser; Hemiaulus polycystinorum Ehrenberg var. simbriskianus Grunow 1884: 65, Tab. II(B), figs. 44, 45; Jousé et al. 1949: Vol. 2, p. 185 , Tab. 71, fig. 4; Hemiaulus rossicus Pantocsek
1889: Bd. 2, p. 84; Strelnikova 1974: 102-103, Tab. 43, figs. 1-18; Harwood 1988: 83, figs. 14.18-21, 15.4-5; Hemiaulus polycistinorum var. brevicornis Jousé 1951: 54, Tab. 4, figs. a-c; Cortinocornus rossicus (Pantocsek) Gleser 1984: 290-291. [Plate III, figs. 5-8]

Coscinodiscus polymorphus Strelnikova 1974: 65-66, Tab. 3, figs. 8-17.

Costopyxis antiqua (Jousé) Gleser; Stephanopyxis antiqua Jousé 1951: 46, Tab. 1, figs. 3a,b; Strelnikova 1974: 56, Tab. 3, figs. 18-20; Fenner 1985: 738, figs. 14.13-14; Stephanopyxis cancellata Jousé 1951: 46, Tab. I, figs. 4a,b; Costopyxis antiqua (Jousé) Gleser 1984: 292; Gleser et al. 1988: 49, Tab. 31, figs. 1-3, 6. [Plate II, figs. 10-11, 14-15]

Costopyxis ornata (Schulz) Strelnikova; Stephanopyxis ornata Schulz 1935: 397, Tab. 2, fig. 4; Jousé et al. 1949: Vol. 2, p. 41, Tab. 79, fig. 3; Strelnikova 1974: 56, Tab. 4, figs. 4-7, 9a,b; Fenner 1985: 738, fig. 14.7; Costopyxis schulzii Steinecke forma ornata (Schulz) Strelnikova, Gleser et al. 1988: 51, Tab. 32, figs. 1-4, 9-16. [Plate I, figs. 15-16]

Costopyxis reticulata (Long, Fuge et Smith) Gleser; Stephanopyxis reticulata Long, Fuge and Smith 1946: 111, Pl. 19, fig. 9; Strelnikova 1965b: 29, Tab. 1, figs. 1-6; Strelnikova 1974: 57, Tab. 5, figs. 7-13; Fourtanier 1991: 201, Pl. 5, fig. 11; Costopyxis reticulata (Long, Fuge et Smith) Gleser 1984: 292; Gleser et al. 1988: 50, Tab. 31, figs. 10-14. [Plate VI, fig. 6] 
TABLE 5

Selected diatom data (total counts) from Horton River composite Section, fraction greater than $25 \mu \mathrm{m}$. Preservation: $\mathrm{G}=\mathrm{Good}, \mathrm{M}=\mathrm{Moderate}, \mathrm{P}=\mathrm{Poor}$; Relative Abundance: $\mathrm{A}=$ Abundant, $\mathrm{C}=$ Common, $\mathrm{F}=\mathrm{Few}, \mathrm{R}=$ Rare, $\mathrm{P}=$ Present.

\begin{tabular}{|c|c|c|c|c|c|c|c|c|}
\hline & & EAR & Y CAMPA & & & & & \\
\hline Horton River, $>25$ mierons, $<2.2 \mathrm{SG}$ & 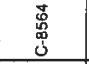 & $\begin{array}{l}\text { 品 } \\
\text { 品 } \\
\end{array}$ & 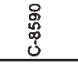 & 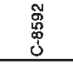 & 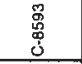 & $\begin{array}{l}\text { 只 } \\
0 \\
0 \\
0 \\
\end{array}$ & $\begin{array}{l}\text { 怘 } \\
\text { 品 } \\
\end{array}$ & $\begin{array}{l}\hat{9} \\
\text { 总 } \\
\text { U } \\
\end{array}$ \\
\hline Outcrop samplo interval (m) & $21.3-24.4$ & $97.5-100.6$ & $0.0-30$ & $6.1-9.1$ & $9.7-12.2$ & $15.2-18.3$ & $18.3-21.3$ & $21.3-24.4$ \\
\hline Average outcrop olevation (m) & 22.85 & 99.05 & 1.52 & 7.62 & 10.67 & 16.76 & 19.81 & 22.86 \\
\hline Preservation & M & M & $P$ & $P$ & $\mathbf{P}$ & M & $\mathrm{M}$ & M \\
\hline Abundanc: & $\mathrm{R}$ & $\mathrm{R}-\mathrm{F}$ & $\mathrm{c}$ & $F$ & $\mathrm{~F}$ & $\mathrm{c}$ & $\mathrm{F}$ & $\mathrm{F}$ \\
\hline Actinodyction weissflogii & & & & & & & & \\
\hline Actinoptychus simbriskianus & & & & & & & & \\
\hline Actinoptychus tenuis & & & 2 & & & 6 & $i$ & 3 \\
\hline Actinoptychus tuberculatus & & & & & & & & 2 \\
\hline Anaulus sp. al. A sibericus & & & & & & & & \\
\hline Aulacodiscus breviprocesus & & & & & & & & \\
\hline Aulacodiscus septus $\mathrm{f}$. quattuorradiata & 1 & & 1 & & 3 & 1 & 2 & \\
\hline Autacodiscus soptus t. septus & & & & & & 2 & 3 & \\
\hline Biddulphía gnunowi & & & & & & & & \\
\hline Corinna sp. 1 & & 1 & & & 2 & & 3 & 3 \\
\hline Continocomus rossicus & & & 1 & & 6 & 10 & 16 & 28 \\
\hline Coscinodiscus polymorphus & & & & & & 3 & & 2 \\
\hline Costopyxis antiqua & & & 3 & & & & & \\
\hline Costopyxis omata & 2 & 48 & 176 & 8 & 21 & 1 & 1 & 1 \\
\hline Costopyxis reficulata & & & & & & & 1 & \\
\hline Costopyxis schulzif t. nuda & & & 5 & & 2 & & & \\
\hline Costopyxis schulzii f. shulzii & & 6 & 12 & 1 & 11 & & & \\
\hline Eunotogramma bivitata & & & & & & & & \\
\hline Eunotogramma enorme & & & & & & & & \\
\hline Gladiopsis spaciosus f aculaolatus & . & & & & & 1 & & \\
\hline Gladiopsis speciosus f. poratus & & & & & & & & \\
\hline Gladiopsis speciosus f. speciosus & 1 & & 5 & 4 & 4 & & 2 & 1 \\
\hline Gonjothecium odontella & & & & & 5 & 1 & 4 & 7 \\
\hline Goniothecium odontella var. danica & & 1 & & & & & & \\
\hline Hemiaulus altus & & & & & & 2 & 2 & 4 \\
\hline Hemiaulus antiques & & & 2 & & $\ldots .$. & & & 3 \\
\hline Hemiaulus arcticus & & & & & & & & \\
\hline Hemiaulus curvatuius & & 1 & & & & 1 & 2 & 11 \\
\hline Hemiaulus danicus & & & & & & & 1 & \\
\hline Hemiaulus achinulatus & & & & & & & 12 & 11 \\
\hline Hamiaulus elogans & & & 2 & & 1 & & 3 & 1 \\
\hline Hemiaulus februatus & & & & & & & 2 & 4 \\
\hline Hemiaulus kittoni & & & & & 4 & 7 & & 6 \\
\hline Hemia ulus orthoceras & & 1 & 6 & 1 & 3 & 3 & 4 & \\
\hline Hemiaulus polymorphus var. frigida & 1 & 1 & 2 & & $?$ & 5 & 18 & 18 \\
\hline Hemiaulus praelegans & & & & & & & & \\
\hline Hemiaulus punctatus & & & & & & & & \\
\hline Hemiaulus schmidti & & 1 & & & 1 & $B$ & 7 & 10 \\
\hline Hemiaulus sporalis (spores) & 3 & 2 & & & 16 & 2 & 3 & 2 \\
\hline Hemiaulus sporalis (vegetative cell) & & & & & 1 & & & 3 \\
\hline Hemiaulus tumidicornis & & & & & & & & \\
\hline Homiaulus undulatus & & & & & & & & \\
\hline Meristiosolen sp. 1. & $i$ & & & & & & 1 & 6 \\
\hline Micrampula panula & & & & & & 1 & 5 & 6 \\
\hline Odontotropis carinata & & & & 1 & & & 1 & 2 \\
\hline Odontotropis cristata & & & & & & 1 & & \\
\hline Odontotropis hyalina & & & & & 1 & & & \\
\hline Paralia omata & & & & & & & & \\
\hline Paralia sulcata & 1 & & & 1 & 28 & 20 & 53 & 57 \\
\hline Prosbocia cretacea & & & & & & & & 3 \\
\hline Psoudopodosira reticulata & & & & & & & & \\
\hline Pseudopyxilla sp. ef. P. rossica & & & & & 2 & & & \\
\hline Plerotheca aculeifera & & 1 & & 1 & 6 & 6 & 4 & 5 \\
\hline Pferotheca sp. ct. P. spadt & & & & & & & & \\
\hline Pierotheca crotacea & & & & & & & & \\
\hline Pterotheca pokrovskajae & & & & 1 & 2 & & & \\
\hline Sceptroneis grunowii & & & & & & 1 & 3 & 4 \\
\hline Spore \# 3 & 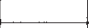 & & & & & & & \\
\hline Spore *4 & & & & & & & & \\
\hline Spore \# 12 & & & & & & 3 & 1 & \\
\hline Shoshukovia sp. 1 & & & & 2 & & 10 & 7 & 1 \\
\hline Stellarime steinyi & & 2 & 13 & & 2 & 2 & 3 & 1 \\
\hline Stophanopyxis arctica & & & & & & 24 & 1 & \\
\hline Stephanopyxis superba & & & & & & 15 & 2 & 4 \\
\hline Stephanopyxis dissonus & & & & & & 49 & 12 & 18 \\
\hline Stephanopyxis dissonus var. & & & & & & & & \\
\hline Stephanopyxis grunow & 7 & & 1 & & 6 & 80 & 38 & 23 \\
\hline Stephanopyxis lavrenkoi & 2 & & & & & & & \\
\hline Stephanopyxis simonseni & & & & & & & & \\
\hline Stephanopyxis turris & & & 2 & & 2 & 5 & 2 & \\
\hline Strelnikovia antiqua & & & & & & & & 1 \\
\hline Thalassiosiropsis wittian & 4 & & & & & 38 & 31 & 21 \\
\hline Triceratium kolbei & & & & & & & & \\
\hline Triceratium planum & & & & & & & & \\
\hline Triceratium synicum & & & & & & & & \\
\hline Trinacria acutangula & 4 & & 1 & & & 54 & 30 & 29 \\
\hline Trinacria aries & & & & & & & & \\
\hline Trinacria coronatum & & & & & & & & \\
\hline Irinacria excavata & & & & & & & & \\
\hline Trinacria indefinita & 2 & & & & 10 & 13 & 17 & 17 \\
\hline Trinacria tessela & & & & & & 1 & 2 & 1 \\
\hline Trochosiropsis polychaeta & 2 & & & & & & 1 & 1 \\
\hline Other diatoms (including resting spores) & 1 & 4 & 12 & 1 & 13 & 15 & 38 & 34 \\
\hline TOTAL DIATOMS & 32 & 69 & 246 & 21 & 159 & 391 & 339 & 354 \\
\hline
\end{tabular}


TABLE 5

Contninued.

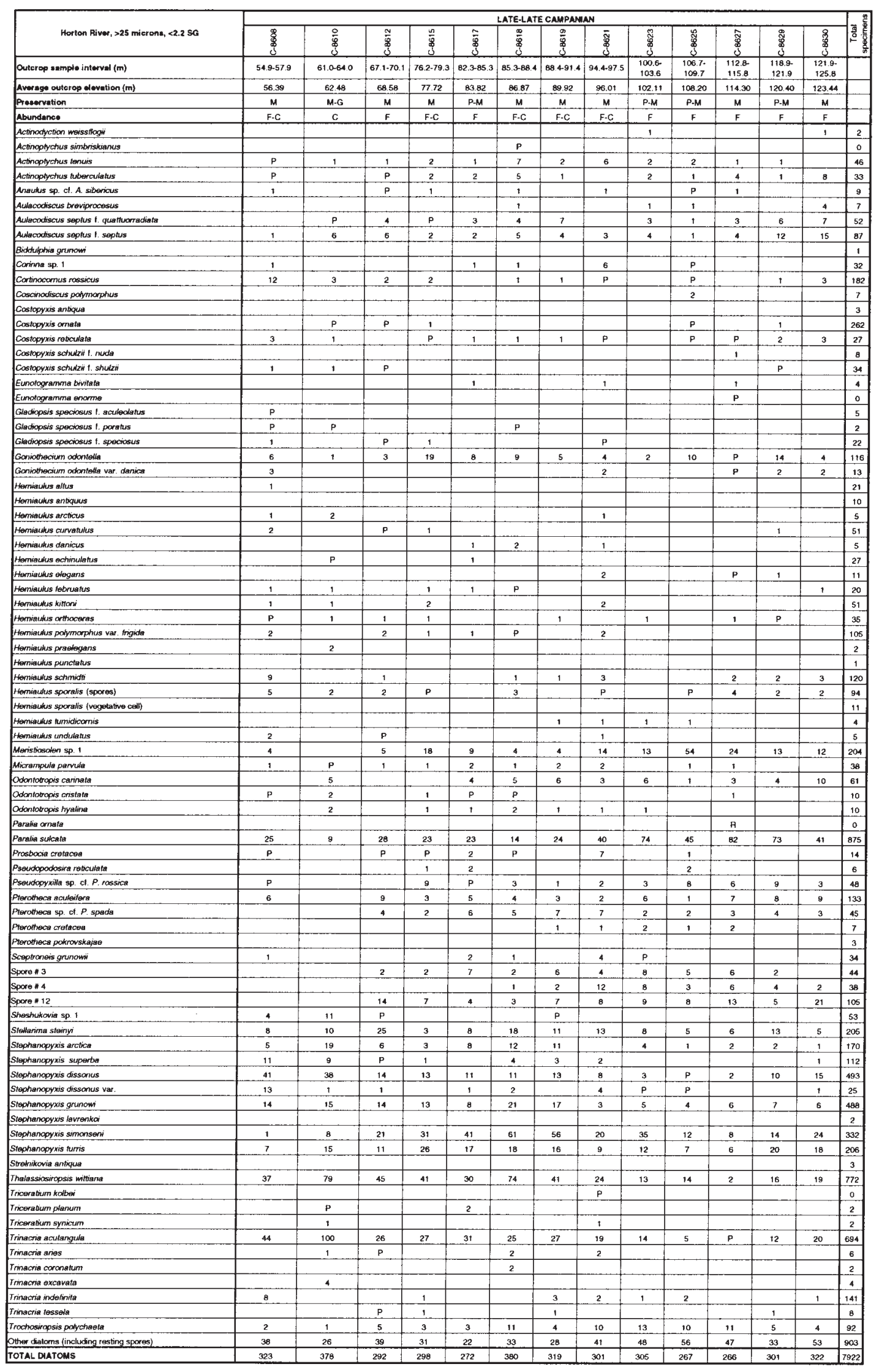


TABLE 6

Selected diatom data (total counts) from Horton River composite Section, fraction lesser than $25 \mu \mathrm{m}$. Preservation: $\mathrm{G}=\mathrm{Good}, \mathrm{M}=\mathrm{Moderate}, \mathrm{P}=\mathrm{Poor}$; Relative Abundance: $\mathrm{A}=\mathrm{Abundant}, \mathrm{C}=\mathrm{C}$ Common, $\mathrm{F}=\mathrm{Few}, \mathrm{R}=\mathrm{Rare}, \mathrm{P}=$ Present.

\begin{tabular}{|c|c|c|c|c|c|c|c|c|c|c|c|c|c|c|}
\hline \multirow[b]{2}{*}{ Horton River, $<25$ microns, $<2.2 \mathrm{SG}$} & \multicolumn{5}{|c|}{ EARLY CAMPANIAN } & \multicolumn{9}{|c|}{ EARLY-LATE CAMPANIAN } \\
\hline & $\begin{array}{l}\text { 离 } \\
\text { 品 } \\
\dot{0}\end{array}$ & 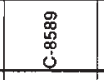 & $\begin{array}{l}8 \\
\text { 怘 } \\
\text { j } \\
\end{array}$ & 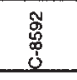 & $\begin{array}{l}0 \\
\text { 多 } \\
\text { S } \\
\end{array}$ & $\begin{array}{l}\text { 吕 } \\
\text { 怘 } \\
\text { S. }\end{array}$ & 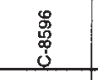 & $\begin{array}{l}\text { 总 } \\
\text { 品 } \\
\text { S. }\end{array}$ & $\begin{array}{r}\mathbf{8} \\
\stackrel{8}{8} \\
0 \\
0 \\
\end{array}$ & $\begin{array}{l}8 \\
8 \\
\$ \\
0 \\
\end{array}$ & $\begin{array}{l}\bar{O} \\
\dot{8} \\
\dot{0} \\
\end{array}$ & 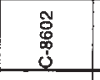 & $\begin{array}{l}0 \\
8 \\
0 \\
0 \\
j \\
\end{array}$ & $\begin{array}{l}\hat{8} \\
\text { 今 } \\
ن \\
ن\end{array}$ \\
\hline Outcrop samplo interval (m) & $21.3-24.4$ & $\mid 97.5-100.6$ & $0.0-3.0$ & $6.1-9.1$ & 9.1-12.2 & 15.2-18.3 & 18.3-21.3 & 21.3-24.4 & 27.4-30.5 & $30.5-33.5$ & $33.5-36.6$ & 36.6-39.6 & $39.2-42.7$ & $51.2-54.9$ \\
\hline Average outcrop elevation $(\mathrm{m})$ & 22.85 & 99.05 & 1.52 & 7.62 & 10.67 & 16.76 & 19.81 & 22.86 & 28.96 & 32.00 & 35.05 & 38.10 & 41.15 & 53.34 \\
\hline Preservation & M & $M$ & $\mathrm{M}$ & $P$ & P-M & $M$ & $M$ & $\mathrm{M}$ & $M$ & $M$ & $M$ & $M$ & $M$ & $M$ \\
\hline Abundance & $\mathrm{R}$ & $\mathrm{A}$ & $\mathrm{A}$ & $\mathbf{R}$ & $\mathbf{R}$ & F-C & $c$ & C & $\mathrm{c}$ & $\mathrm{c}$ & $c$ & $\mathrm{~F}-\mathrm{C}$ & F-C & F-C \\
\hline Actinoptychus tenuis & & 1 & & & & 1 & 1 & & & & 1 & & & 1 \\
\hline Actinoptychus tuberculalus & & & & & & $\mathrm{P}$ & & & $P$ & & & & & \\
\hline Anaulus sp. cf. A sibericus & & & & & & 1 & & 1 & & 1 & $P$ & & & 1 \\
\hline Aulacodiscus septus f, septus & & & & & & 1 & $P$ & & $\mathbf{P}$ & & & 1 & & 1 \\
\hline \multicolumn{15}{|l|}{ Basilicostephanus sp. 1.} \\
\hline Corinna sp. 1 & & & & & & $\mathrm{P}$ & & 1 & 2 & & 1 & 2 & & \\
\hline Cortinocomus rossicus & 2 & & & 3 & 5 & 13 & 17 & 10 & 14 & 7 & 10 & 12 & 1 & 5 \\
\hline Costopyxis antiqua & & & & & 4 & & & & & & & & & \\
\hline Costopyxis omata & & 29 & 34 & 7 & 6 & & & & & $P$ & & & & $\mathrm{P}$ \\
\hline Costopyxis reticulata & 1 & & & & & 2 & 2 & & 4 & 4 & 1 & $P$ & 1 & 3 \\
\hline Costopyxis schulzii f. shutzii & & 30 & 2 & & 1 & & & & & & & & & \\
\hline Costopyxis schulzii var, nuda & & 19 & 45 & 1 & 4 & & & & $\mathrm{P}$ & & & & & \\
\hline Eunotogramma bivitata & & & & & & & & & & & & 1 & & \\
\hline Gladiopsis speciosus f. aculoolatus & & & & & & & 1 & $P$ & 1 & 1 & $P$ & & $P$ & \\
\hline Gladiopsis speciosus 1 . speciosus & & & $\mathrm{P}$ & & 4 & 1 & 1 & 2 & 3 & 2 & 2 & 1 & $\mathbf{P}$ & 1 \\
\hline Goniothecium odontella & 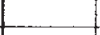 & & & & 1 & 3 & 5 & & 1 & 2 & & 2 & & \\
\hline Goniothecium odontella var. danica & & & & & 1 & & & & & & 3 & & & \\
\hline Hemiaulus altus & 1 & & & & & & 3 & 1 & 1 & & 1 & & & 3 \\
\hline Hemiaufus antiquus & & & & & 5 & & & & & & & 1 & & \\
\hline Hemiaulus arcficus & & & & & & 1 & & & & & & & & \\
\hline Hemiaulus sp. of. H. polymorphus & 1 & & & & & & & 1 & & & & & & \\
\hline Hemiaulus curvatulus & & & & & & 2 & 1 & & 1 & 3 & 3 & & & 1 \\
\hline Hemiaulus echinulatus & & & & & & & & & 1 & & 1 & 1 & & \\
\hline Hemiaulus februatus & & & & & & 3 & & & & 1 & & 1 & & 1 \\
\hline Hemiaulus kittonii & & & & & & 2 & & 2 & 1 & 3 & 2 & & 1 & 1 \\
\hline Hemiaulus polymorphus var. frigida & & 4 & 3. & & & 7 & 7 & & 12 & 2 & 1 & 11 & & 2 \\
\hline Hemiautus praelegans & & & & & & & & & & & & & & \\
\hline Hemiaulus punctatus & & & & & & & & & & & & & & \\
\hline Hemiaulus schmidti & 3 & & & & 4 & 22. & 14 & 11 & 10 & 7 & 6 & 4 & $P$ & 5 \\
\hline Hemiaulus sporalis (spores) & 3 & 10 & 3 & 1 & 4 & 1 & 5 & 6 & 5 & 4 & 6 & 5 & $P$ & 4 \\
\hline Hemiaulus sporalis (vegetative cell) & & & & & & & & & & & $\mathbf{P}$ & & & 1 \\
\hline Hemiaulus undulatus & . & & & & & 1 & & & & & & & & \\
\hline Melosira? hokaidoana & & & & & & & & . & & $P$ & 1 & & & \\
\hline Meristiosolen sp. 1 & 3 & & & & & 9 & 5 & 1 & 8 & 4 & 2 & 6 & 2 & 7 \\
\hline Micrampula parvula & 1. & & & & & 2 & 1 & 1 & 3 & 4 & 2 & $t$ & 2 & 1 \\
\hline Odontotropis carinata & & & & & & & 1 & & & & & & & \\
\hline Paralia omata & & & & & & & & & & & & $R$ & & \\
\hline Paralia sulcata & 21 & & 1 & & 23 & 41 & 49 & 47 & 47 & 38 & 27 & 37 & 9 & 27 \\
\hline Proboscia cretacea & & & & & & & & & 1 & & & $P$ & & \\
\hline Pseudopodosira reticulata & & & & & & & & & & & & & & \\
\hline Pseudopyxilla sp. cf. P. rossica & 1 & & & & & 1 & 2 & 1 & 2 & & $P$ & 2 & 2 & $P$ \\
\hline Plerotheca aculeifera & & 2 & & 1 & 15 & 8 & 4 & 3 & 1 & 6 & 5 & 3 & 3 & 3 \\
\hline Pterotheca sp. cf. P. spada & & & & & $P$ & & & & & & $P$ & & & \\
\hline Pterotheca cretacea & & & & & & & & & & & & & & 1 \\
\hline Raphoneis elliptica & & & & & & 1 & & & & 1 & & & & 1 \\
\hline Sceptroneis gracilis & & & & & & & & & & & & & & \\
\hline Sceptroneis grunowi & & & & & & & & 4 & 2 & 3 & 1 & & 1 & 1 \\
\hline Sheshukovia sp. 1 & & & & & & & 2 & & $P$ & $P$ & & $P$ & & $P$ \\
\hline Spore \# 3 & & & & & & & & & & & & & & \\
\hline Spore \#4 & & & & & & & & & & & & & & \\
\hline Spore \# 12 & & & & & & & & & & & & & & \\
\hline Stellarima steinyi & 2 & 1 & 2 & & & 4 & 2 & & 1 & $\mathrm{P}$ & $\mathbf{P}$ & 1 & & \\
\hline Stephanopyxis arctica & & & & & & & & 1 & & & & & & \\
\hline Stephanopyxis dissonus & & 3 & & & 5 & 4 & 4 & 2 & $P$ & $P$ & 1 & $P$ & & \\
\hline Stephanopyxis dissonus var. & & & & & & & & & & & & & & \\
\hline Stephanopyxis gnunowi & & & & & & & 1 & & & & & 1 & & \\
\hline Stephanopyxis simonseni & & & & & & & & & & & & & & \\
\hline Stephanopyxis turris & 1 & 1. & & & 5 & 3 & 1 & 3 & 3 & $\mathbf{P}$ & 2 & 1 & & \\
\hline Strefnikovia antiqua & & & & & & & 1 & & & & & & & \\
\hline Thalassiosiropsis wittiana & & & & & & 2 & 1 & 1 & & & & & & \\
\hline Triceratium indefinitum sensu Strelnikova (1974) & & & & 1 & 4 & & & & & & & & & \\
\hline Triceratium planum & & & & & & & & & & & 1 & & & \\
\hline Triceratium schulzii & & & & & 1 & & & & & & & & & \\
\hline Triceratium synicum & & & & & $P$ & & & & & & & & & \\
\hline Trinacria acutangulum & 1 & & & & & 16 & 11 & 7 & 9 & 2 & 13 & 9 & 1. & 5 \\
\hline Trinacria indefinita & 3 & & & & & 10 & 5 & 4 & $\mathbf{P}$ & 2 & & 4 & $\mathbf{P}$ & 1. \\
\hline Trinacria tessela & & & & & & 1 & & & & & & & & \\
\hline Trochosiropsis polychaeta & & & & & 1 & 2 & 2 & 1 & $\mathbf{P}$ & 4 & & 2 & & 2 \\
\hline Other diatams (including resting spores) & 11 & 13 & 21 & 18 & 8 & 47 & 29 & 35 & 47 & 31 & 38 & 25 & 14 & 37 \\
\hline TOTAL DIATOMS & 55 & $1+3$ & 111 & 32 & 101 & 212 & 178 & 146 & 180 & 132 & 131 & 134 & 37 & 116 \\
\hline
\end{tabular}


TABLE 6

Continued.

\begin{tabular}{|c|c|c|c|c|c|c|c|c|c|c|c|c|c|c|}
\hline \multirow[b]{2}{*}{ Horton River, $<25$ microns, $<2.2 \mathrm{SG}$} & \multicolumn{13}{|c|}{ LATE-LATE CAMPANIAN } & \multirow{2}{*}{ 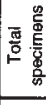 } \\
\hline & 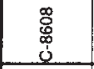 & $\begin{array}{l}\circ \\
\stackrel{0}{0} \\
\dot{j} \\
\end{array}$ & $\begin{array}{r}N \\
\stackrel{N}{0} \\
\dot{0} \\
\end{array}$ & $\begin{array}{r}\frac{\omega n}{8} \\
\$ 0 \\
\\
\end{array}$ & $\begin{array}{l}\hat{\mathbf{w}} \\
\dot{\$} \\
\mathcal{i}\end{array}$ & 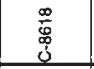 & 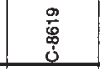 & 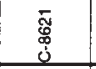 & 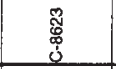 & 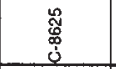 & 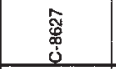 & $\begin{array}{l}\mathbb{8} \\
\$ \\
8 \\
\end{array}$ & 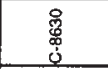 & \\
\hline Outcrop samplo interval ( $m$ ) & \begin{tabular}{|l|}
$54.9-57.9$ \\
\end{tabular} & $61.0-64.0$ & $67.1-70.1$ & $76.2-79.3$ & $82.3-85.3$ & \begin{tabular}{|l|}
$85.3-88.4$ \\
\end{tabular} & $88.4-91.4$ & \begin{tabular}{|l|}
$94.4-97.5$ \\
\end{tabular} & $100.6-103.6$ & \begin{tabular}{|l|}
$106.7 \cdot 109.7$ \\
\end{tabular} & $112.8-115.8$ & $118.9-121.9$ & $121.9-125.8$ & \\
\hline Avorage outcrop olevation (m) & 56.39 & \begin{tabular}{|l|}
62.48 \\
\end{tabular} & \begin{tabular}{|l}
68.58 \\
\end{tabular} & 77.72 & 83.82 & 86.87 & 89.92 & 96.01 & 102.11 & 108.20 & 114.30 & 120.40 & 123.44 & \\
\hline Proservation & $\mathrm{M}$ & M & M & $\mathrm{M}$ & P-M & $\mathrm{M}$ & $\mathrm{M}$ & M & M-G & M & P-M & M & M & \\
\hline Abundance & $F-C$ & F-C & $F$ & $\mathrm{~F}-\mathrm{C}$ & $c$ & $c$ & $c$ & $F \cdot C$ & $\mathrm{c}$ & $\mathrm{F}$ & $\mathrm{F}$ & $F$ & F-C & \\
\hline Actinoptychus tenuis & 1 & & & 3 & 1 & & 2 & 1 & 1 & 2 & $P$ & $P$ & & 16 \\
\hline Actiroptychus tuberculatus & & & & 1 & & & & 1 & & & & & $i$ & 3 \\
\hline Anaulus sp. ct. A. sibericus & & & $P$ & & $\mathrm{P}$ & & 1 & & & & $P$ & 2 & & 7 \\
\hline Aulacodiscus septus f. septus & 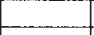 & & & & & & & & $P$ & & $P$ & & & 3 \\
\hline Basilicastephanus sp. 1 & & & A & & & & & & & & & & & 0 \\
\hline Corinna sp. 1 & & 2 & & $P$ & 4 & $P$ & & & & $P$ & & & & 12 \\
\hline Continacomus rassicus & 2 & 5 & 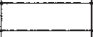 & $P$ & & & 1 & & & & & 3 & 1 & 111 \\
\hline Costopyxis antiqua & & & & & & & & & & & & & & 4 \\
\hline Costopyxis omata & & & & & & & & & $P$ & & & & & 76 \\
\hline Costopyxis reticulata & 2 & 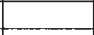 & $P$ & & & $P$ & & & & & & & 1 & 21 \\
\hline Costopyxis schulzii f. shulzii & & & & & & & & & $\ldots$ & & & & & 33 \\
\hline Costopyxis schulzi var. nuda & & & & & & & & & & 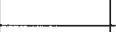 & & & & 69 \\
\hline Eunotogramma bivitata & & & & & & $\mathrm{P}$ & & & & & & & & 1 \\
\hline Gladiopsis spociosus f. aculeolatus & 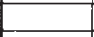 & & & & & & & & & & & & & 3 \\
\hline Gladiopsis speciosus f. speciosus & & & $P$ & & & & & & 1 & & & $\bar{P}$ & & 18 \\
\hline Goniothecium odontella & & 1 & $\mathrm{P}$ & 9 & 2 & 1 & 2 & 5 & 5 & 1 & $P$ & 2 & $p$ & 42 \\
\hline Goniothecium odontella var. danica & & & & & & & & & $\mathbf{P}$ & & & & & 4 \\
\hline Hemiaulus afus & 2 & & & 1 & & & ـ & - & & & & $\ldots$ & & 13 \\
\hline Hemiaulus antiquus & & & & & & & & & & & & & 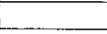 & 6 \\
\hline Hemlautus arcticus & _. & & & & & 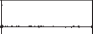 & & & & & & & & 1 \\
\hline Hemiaulus sp. A1. H. polymorphus & & & $P$ & & & & & & & & & & & 2 \\
\hline Hemiaulus curvatulus & 1 & $t$ & & 1 & 1 & 1 & & 1 & & 2 & & & -.. & 19 \\
\hline Hemiaulus echinulatus & & & & & & & & & & & & & & 3 \\
\hline Hemiaulus februatus & & & & $\mathrm{P}$ & & & $\mathrm{P}$ & - & $p$ & & & & $P$ & 6 \\
\hline Hemiaulus kittonii & & 2 & & 1 & $\mathbf{P}$ & & & & & & & & & 15 \\
\hline Hemiaulus polymorphus var, frigita & $P$ & & & & & & & $P$ & & & & & & 49 \\
\hline Hemiautus praelegans & & & & & & & & & 1 & & & & & 1 \\
\hline Hemiaulus punctatus & & 1 & & & & & & & & & & & & 1 \\
\hline Hemiaulus schmikti & 5 & 2 & 2 & 1 & $\mathrm{P}$ & $\mathrm{P}$ & $P$ & $P$ & & & & $P$ & & 96 \\
\hline Hemiaulus sporalis (spores) & 1 & 1 & $P$ & & $\mathbf{P}$ & & & & 2 & $\mathrm{P}$ & 2 & & 4 & 67 \\
\hline Hemiaulus sporalis (vegotative celli) & 1. & & & & $\mathbf{p}$ & & & & & & & & & 2 \\
\hline Hemiauius undulatus & & & & & & & $\mathbf{P}$ & & & & & & & 1 \\
\hline Melosira? hokaidoana & & & & & & & & & & & & & & 1 \\
\hline Meristiosolen $s p .1$ & 2 & & 10 & 7 & 2 & 4 & 13 & 7 & 9 & 20 & 5 & 3 & 5 & 134 \\
\hline Micrampula parvula & 2 & 6 & & $P$ & 2 & 2 & 1 & $P$ & & & & 1 & $\vec{p}$ & 32 \\
\hline Odontotropis carinata & & & & & & & & & & & & & & 1 \\
\hline Paralia omata & & & & $\mathbf{R}$ & & $R$ & & & & & & & & 0 \\
\hline Paralia sulcata & 11 & 12 & 11 & 13 & 4 & 16 & 17 & 28 & 46 & 11 & 25 & 43 & 28 & 632 \\
\hline Proboscia cretacea & & & & & 1 & & 1 & & & & & & & 3 \\
\hline Psevdopodosira roticulata & & 2 & & & & & & & & & & & $P$ & 2 \\
\hline Pseudopyxilla sp. of P. rossica & 2 & & 2 & 4 & $P$ & 2 & & 2 & 3 & 12 & 3 & 8 & 3 & 52 \\
\hline Pterotheca aculeifera & 8 & 5 & 2 & 4 & 2 & 3 & 2 & 1 & 2 & 1 & 1 & & & 85 \\
\hline Pterotheca sp. ct. P. spada & & 1 & $P$ & & & $P$ & $P$ & & $\mathbf{P}$ & & & & & 1 \\
\hline Pferothoca cretacea & & & & & & & & $P$ & $P$ & $\mathrm{P}$ & $P$ & & & 1 \\
\hline Aaphoneis elliptica & & & & & & 1 & & & & & 2 & & & 6 \\
\hline Sceptroneis gracilis & & 1 & & & & & & & & & & & & 1 \\
\hline Scepproneis grunowi & $P$ & 3 & $P$ & 1 & $\mathrm{P}$ & 2 & $\mathrm{P}$ & 3 & 5 & & & & $\mathbf{P}$ & 26 \\
\hline Sheshukovia sp. 1 & 1 & & & & & & & & & & & & $P$ & 3 \\
\hline Spore\#" 3 & & & & 9 & 8 & 7 & 3 & 2 & 8 & 3 & $\mathbf{P}$ & 2 & $P$ & 42 \\
\hline Spore \#4 & & & & & & & & & $P$ & & & $P$ & & 0 \\
\hline Spore 12 & 2 & 2 & 13 & 13 & 1 & 8 & 7 & 2 & 12 & 6 & 5 & 6 & 10 & 87 \\
\hline Stellarima steinyi & & & $P$ & 1 & $\mathrm{P}$ & 1 & & 2 & 2 & & & 1 & 1 & 21 \\
\hline Stephanopyxis arctica & & 1 & & & & & & & & & & & & 2 \\
\hline Stephanopyxis dissonus & 1 & & $\mathrm{P}$ & 1 & & & 1 & $P$ & 2 & $P$ & & & 1 & 25 \\
\hline Stephanopyxis dissonus var. & & & $\mathbf{P}$ & & & $p$ & & & & & & & & 0 \\
\hline Stephamopyxis grunowi & & & & 1 & & & $\mathrm{P}$ & & 1 & & & & & 4 \\
\hline Stephanopyxis simonseni & & & 1 & 3 & 2 & 2 & 7 & & 4 & 1 & $\mathrm{P}$ & 1 & 1 & 22 \\
\hline Stephanopyxis turris & & 1 & 3 & 1 & $\mathrm{P}$ & 1 & 2 & $\mathbf{P}$ & 4 & 1 & & $\mathrm{P}$ & 1 & 34 \\
\hline Strelnikovia antiqua & & & & & & & & & & & & & & 1 \\
\hline Thalassiosiropsis wittiana & & & 1 & & 1 & $P$ & 1 & $\mathrm{P}$ & $P$ & & & & 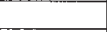 & 7 \\
\hline Triceratium indefinitum sensu Streminiova (1974) & & & & & & & & & & & & & & 5 \\
\hline Triceratium planum & & & & & & & & & & & & & 1 & 2 \\
\hline Triceratium schulzii & & & & & & & & & & & & & & 1 \\
\hline Triceratium synicum & & & & & & & & & & & & & & 0 \\
\hline Trinacria aculangulum & $p$ & 2 & $P$ & 5 & $p$ & 1 & $P$ & & 5 & & 1 & & 1 & \begin{tabular}{|l|l|}
89 \\
\end{tabular} \\
\hline Trinacria indefinita & 2 & 3 & & 1 & & & $P$ & & & 2 & 1 & 1 & & \begin{tabular}{|l|}
39 \\
\end{tabular} \\
\hline Trinacria tessela & & & & & & & & & & & & & & 1 \\
\hline Trochosiropsis porychaeta & 3 & 4 & 4 & 1 & 2 & 2 & 5 & 3 & 10 & 1 & 4 & 4 & 2 & \begin{tabular}{|l|}
59 \\
\end{tabular} \\
\hline Other diatoms (including resting sporos) & 18 & 10 & 16 & 26 & 6 & 21 & 26 & 24 & 44 & 29 & 32 & 41 & 35 & 702 \\
\hline TOTAL DIATOMS & 67 & 68 & 65 & 108 & 39 & 75 & 92 & 82 & 167 & 92 & 81 & 118 & 96 & 2828 \\
\hline
\end{tabular}


Costopyxis schulzii (Steinecke ex Schulz) Gleser; Stephanopyxis schulzii Steinecke ex Schulz 1935: 396, Tab. 1, fig. 12, Tab. 2, figs. 1, 2; Jousé et al. 1949: Vol. 2, p. 41, Tab. 2, fig. 1; Fenner 1985: 739, fig. 14.6; Fourtanier 1991: Pl. 5, fig. 8; Stephanopyxis schulzii var. cretacea Jousé 1949: 65, Tab. 1, figs. 2-4; Jousé et al. 1949: vol. 2, p. 41, Tab. 2, figs. 2a, b. Stephanopyxis schulzii Steinecke forma schulzii Strelnikova 1974: 55, Tab. 4, figs. 1-3, 8; Costopyxis schulzii (Steinecke) Gleser 1984: 291. Costopyxis schulzii (Steinecke) Gleser forma schulzii Gleser et al. 1988: 50, Pl. 31, figs. 15-19.

Costopyxis schulzii Gleser var. nuda Strelnikova; Stephanopyxis schulzii Steinecke forma nuda Strelnikova 1974: 55, Tab. 4, figs. 10-12; Tab. 5, figs. 1, 2. Costopyxis schulzii (Steinecke) Gleser var. nuda Strelnikova; Gleser et al. 1988: 51, Tab. 32, figs. 5-8. [Plate II, figs. 6, 7]

Eunotogramma bivittata Grunow et Pantocsek ex Pantocsek; Eunotogramma? bivittata Grunow et Pantocsek in Pantocsek 1886: Bd. I, p. 50, Tab. 26, fig. 247; Eunotogramma marginopunctatum Long, Fuge et Smith 1946: 105, Tab. 17, fig. 14; Eunotogramma bivittatum Grunow et Pantocsek, Strelnikova 1974: 107, Tab. 52, figs. 6,7; Drepanotheca bivittata (Grunow et Pantosek) Schrader 1969: 123, Pl. 38, fig. 9; Harwood 1988: 80.

Eunotogramma enorme Krotov 1959: 111, fig. 11; Strelnikova 1974: 108-109, Tab. 52, figs. 16-19; Harwood 1988: fig. 21.22.

Gladiopsis speciosus forma aculeolatus Strelnikova; Gladius clavatus Jousé 1951: 55, fig. 1; Pyxilla speciosa forma aculeolata Strelnikova 1966: 35, Tab. 4, figs. 3, 4, 11; Gladius speciosus Schulz forma aculeolatus Strelnikova 1974: 105-106, Tab. 51, figs. 5-10; Gleser et al. 1988: 55, Tab. 35, figs. 1-10. [Plate III, figs. 3-4]

Gladiopsis speciosus forma poratus Strelnikova; Gladius hispidus Jousé 1955: 55, fig. 1; Pyxilla speciosa forma porata Strelnikova 1966a: 35, Tab. 4, figs. 5, 6, 12; Gladius speciosus forma poratus Strelnikova 1974: 106, Tab. 49, fig. 22, Tab. 51, figs. 11, 12; Gleser et al. 1988: 55, Tab. 35, figs. 11-17. [Plate V, figs. 5-6]

Gladiopsis speciosus forma speciosus (Schulz) Strelnikova; Gladius speciosus Schulz 1935: 391, Tab. 1, figs. 6-8;
Jousé et al. 1949: Vol. 2, p. 199, Tab. 97, fig. 4; Jousé 1955: 76, fig. 4; Barron 1985: 141, Pl. 10.2, fig. 14; Fenner 1985: 730, figs. 1-5; Fourtanier 1991: Pl. 5, figs. 9-10; Nikolaev et al. 2001: p. 12-13, Pl. 2, fig. 1-7; Pyxilla speciosa forma speciosa Strelnikova 1966b: 34, Tab. 2, figs. 1-7, Tab. 3, figs. 5-9, Tab. 4, fig. 1, 2, 10; Gladius speciosus forma speciosus (Schulz) Strelnikova; Strelnikova 1974: 104-105, Tab. 49, figs. 2-11, 14, 15, 18 , 20, 21, Tab. 50, figs. 1-19, Tab. 51, figs. 1, 4; Gleser et al. 1988: 55, Tab. 36, figs. 1-10; Gladiopsis speciosa (Schulz) Gersonde et Harwood 1990: 373. [Plate II, fig. 1; Plate V, figs. 1-4]

Gladius antiquus Forti et Schulz; Gersonde et Harwood 1990: 373 , Pl. 7, figs. 1,$2 ; \mathrm{Pl} .8$, figs. $1,2,5,6$; Pl. 15, figs. $6,7$. [Plate I, fig. 2]

Gladius antiquus var. tenuis Gersonde et Harwood 1990: 373, Pl. 7, figs. 3, 4, 10, 11, 15; Pl. 8, figs. 3, 4, 7. [Plate I, fig. 1]

Goniothecium odontella Ehrenberg 1844: 82; Ehrenberg 1854: Tab. 18, fig. 94, Tab. 33, XIII, figs. 13, 14, Tab. 33, XV, fig. 16; Witt 1886: 161, Tab. 7, figs. 7, 8; Jousé et al. 1949: Vol. 2, p. 205, Tab. 75, fig. 10a; Jousé 1951: 60, Tab. 5, figs. 1-7; Hajós and Stradner 1975: 935, Pl. 10, figs. 11-12; Barron 1985: Pl. 10.2, fig. 13; Harwood 1988: 82, figs. 10.21-22; Dell'Agnese and Clark 1994: 38, fig. 3.8; Gonothecium odontellum Ehrenberg, Strelnikova 1974: 116-117, Tab. 55, figs. 1-12, Tab. 56, figs. 1-5.

Goniothecium odontella var. danica Grunow ex van Heurck 1880-1885: Tab. 105, figs. 11, 12; Schulz 1935: 391, Tab. 1, fig. 9; Jousé et al. 1949: Vol. 2, p. 205, Tab. 75, fig. 10b; Jousé 1951: 62, Tab. 5, figs. 8-17; Hajós and Stradner 1975: 935.

Hemiaulus altus Hajós in Hajós et Stradner 1975: 931, Pl. 5, figs. 17-19.

Hemiaulus antiquus Jousé 1951: 52, Tab. 3, figs. 1a, b; Strelnikova 1974: 101, Tab. 46, figs. 1-14; Barron 1985: Pl. 10.2, fig. 4; Dell'Agnese and Clark 1994: 38, fig. 3.9. [Plate IV, figs. 11-12]

Hemiaulus arcticus Grunow 1884: 11 [63], Tab. B, fig. 27. Hemiaulus curvatulus Strelnikova 1971: 49, Tab. 1, figs. 12, 13; Strelnikova 1974: 96-97, Tab. 47, figs. 14-16; Hajós

\section{PLATE 1}

Representative diatom assemblage of the Gladius antiquus Zone.

1 Gladius antiquus var. tenuis Gersonde et Harwood; girdle view, ×1875, Sample C-34348, Slidre Fjord.

2 Gladius antiquus Forti et Schulz; girdle view, $\times 1875$; Sample C-34348, Slidre Fjord.

3-4 Paralia ornata (Grunow) Grunow; girdle view, $\times 1250$, high and low focus of the same specimen; Sample C-34348, Slidre Fjord.

5,6 Trochosira denticulatum (Strelnikova) Tapia; 5, girdle view; 6, valve view, $\times 1875$; Sample C-34348, Slidre Fjord.
7-8 Basilicostephanus sp. 1; girdle view, $\times 1875$; high and low focus of the same specimen; Sample C-34348, Slidre Fjord.

9-10 Bilingua sp. 1; valve view, $\times 1875$, high and low focus of the same specimen; Sample C-34348, Slidre Fjord.

11-12 Hemiaulus sp. A; girdle view, $\times 1875$, high and low focus of the same specimen; Sample C-34348, Slidre Fjord.

13-14 Stephanopyxis sp. A; valve view, $\times 1250$, high and low focus of the same specimen; Sample C-34348, Slidre Fjord.

15-16 Costopyxis ornata (Schulz) Strelnikova; girdle view, $\times 1250$, high and low focus of the same specimen; Sample C-8590, Horton River 

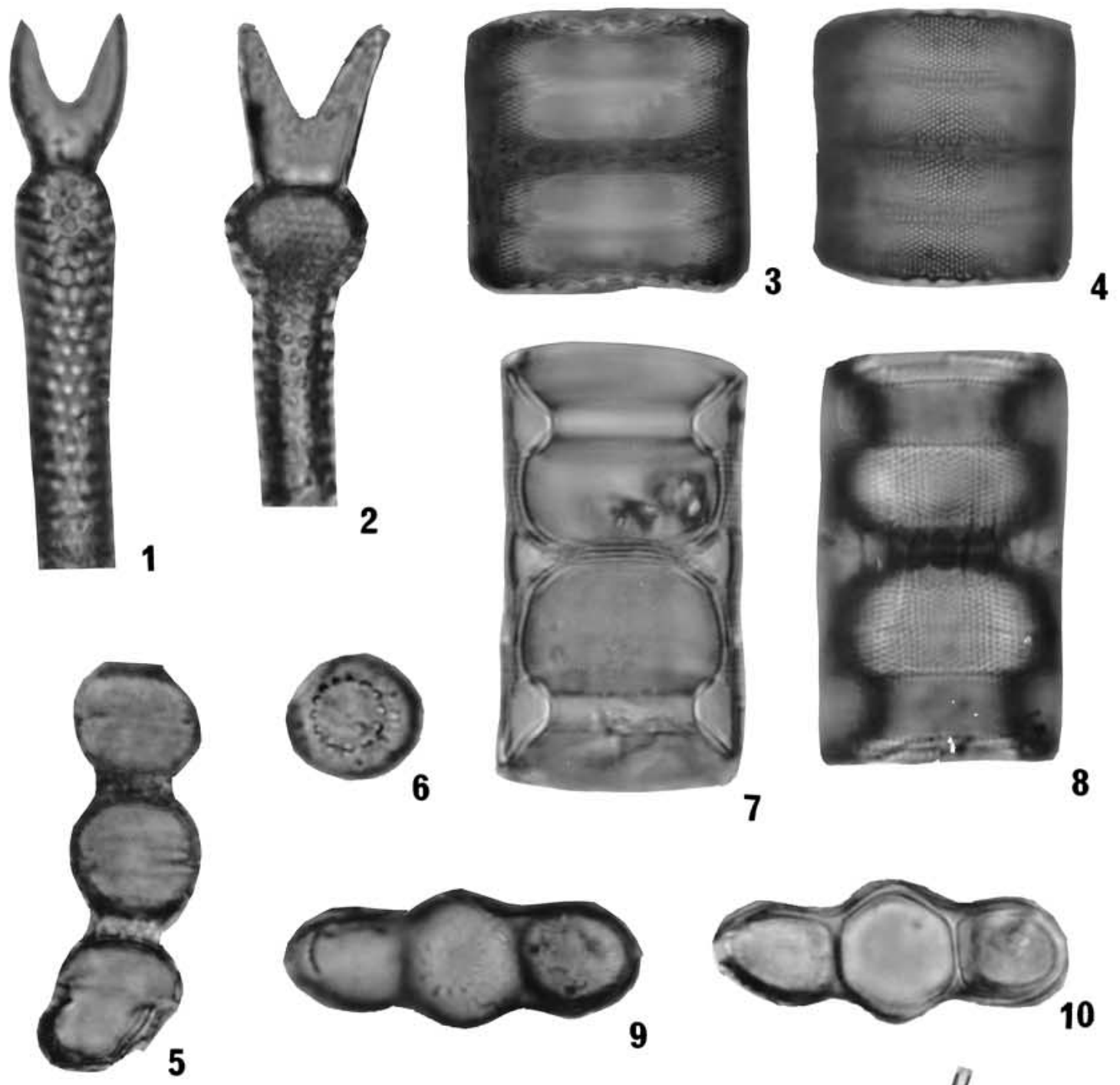

7
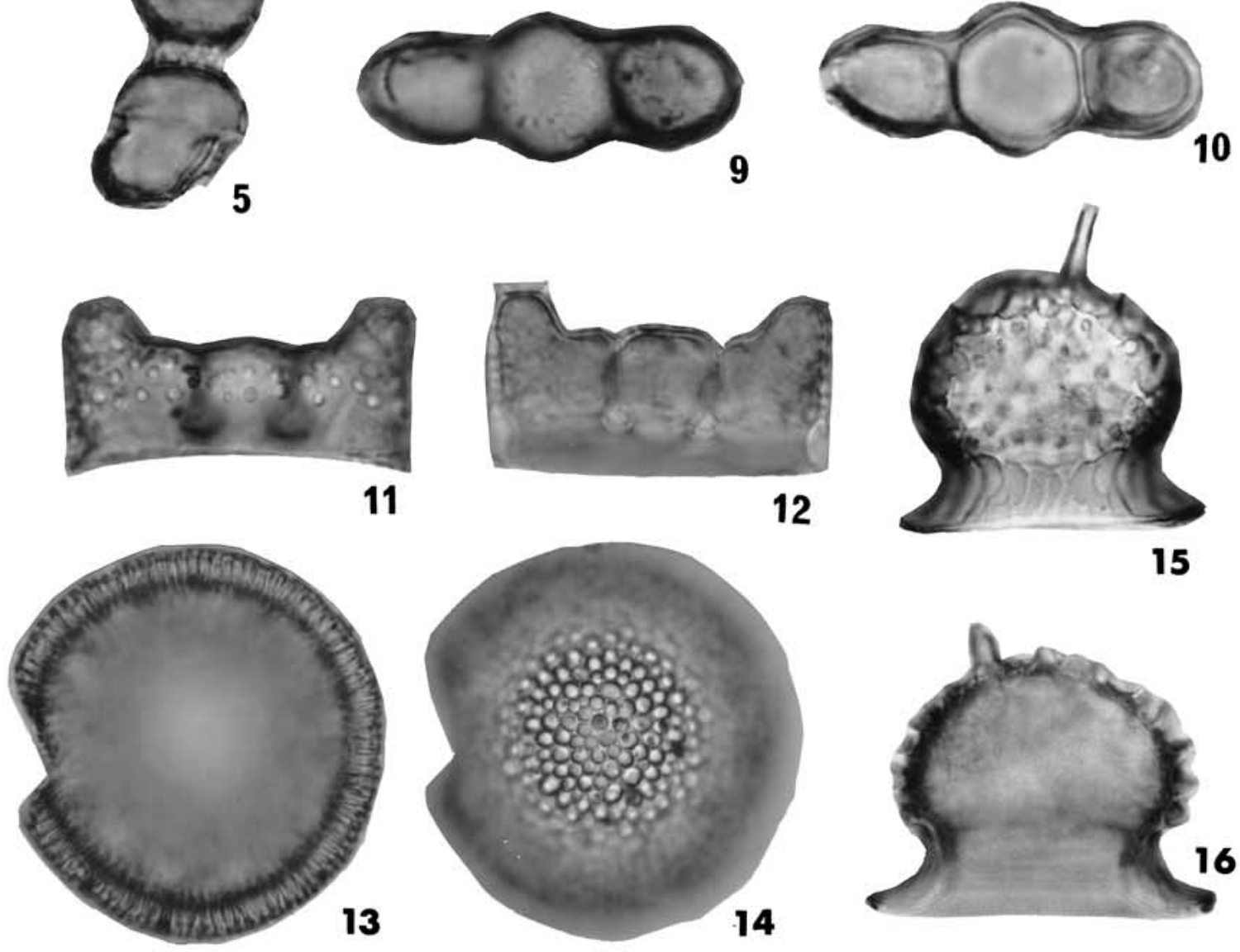

15

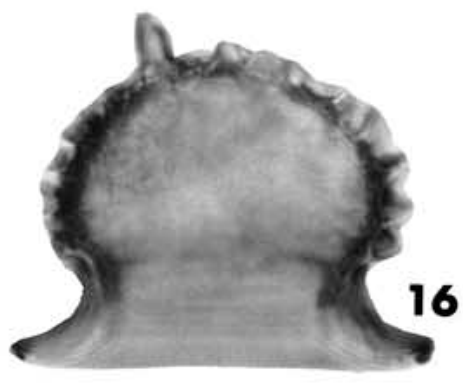


and Stradner 1975: 931, Pl. 6, fig. 8; Harwood 1988: 82, fig. 13.12 .

Hemiaulus danicus Grunow 1884: 65, Tab. II (B), figs. 40, 41; Schmidt et al. 1875-1959: Tab. 143, fig. 43; Hustedt 1930 :877, fig. 521; Jousé et al. 1949: Vol. 2, p. 186, fig. 186, Tab. 72, fig. 11; Strelnikova 1974: 100-101, Tab. 43, fig. 19; Hajós and Stradner 1975: 931, Pl. 5, fig. 10-11; Harwood 1988: 82, figs. 13.16-17.

Hemiaulus echinulatus Jousé in Jousé et al. 1949: Vol. 2: 186, Tab. 72, fig. 5; Jousé 1951: 53, Tab. III, figs. 3a,c; Strelnikova 1974: 100, Tab. 44, figs. 15-23; Hajós and Stradner 1975: 931, Pl. 5, figs. 21, 22; Fenner 1985: 731, fig. 14.10; Harwood 1988: 92, Fig.13.4. [Plate VII, figs. 7-8]

Hemiaulus elegans (Heiberg) Grunow 1884: 14; Strelnikova 1974: 98-99, Tab. 44, fig. 11, 12, 15 (only); Barron 1985: Pl. 10.2, fig. 3; Harwood 1988: 82, fig. 13.18.

Hemiaulus februatus Heiberg 1863: 49, Tab. 2, fig. 5; Homann 1991: 85, Taf. 18, figs. 12, 13.

Hemiaulus kittonii Grunow 1884: 61; Schmidt et al. 1875-1959: Tab. 142, figs. 2-11; Jousé et al. 1949: Vol. 2: 190, Tab. 73, fig. 5, Tab. 95, figs. 8a-d; Barron 1985: Pl. 10.2, fig. 8; Harwood 1988: 83, fig. 13.15; Dell'Agnese and Clark 1994: 38, fig. 4.1; Hemiaulus sp.?: Kitton 1870-1871: Pl. 14, fig. 11.

Hemiaulus orthoceras Strelnikova 1974: 103-104, Tab. 45, figs. 20-24; Fenner 1985: 732, figs. 16-18.

Hemiaulus polymorphus var. frigida Grunow 1884: 66, Tab. 2 (B), figs. 47-49; Hustedt 1930: 881, fig. 525; Jousé et al. 1949: Vol. 2, p. 185, Tab. 71, figs. 6a-d; Krotov and Schibkova 1961: 210: Tab. 3, fig. 13; Strelnikova 1974: 103, Tab. 45, figs. 1-19; Harwood 1988: 83, figs. 14.7, 13.29; Dell'Agnese and Clark 1994: 38, fig. 4.2. [Plate V, fig. 8]

Hemiaulus praelegans Jousé 1951: 53-54, Tab. 3, figs. 4a,b; Krotov 1959: 107-108, fig. 2; Hajós and Stradner 1975: 932, Pl. 6, figs. 12, 14; Harwood 1988: figs. 13.19-20.

Hemiaulus punctatus Greville 1865: 28, Pl. III, fig. 7.

Hemiaulus schmidti Hajós ex Hajós et Stradner 1975: 932, Pl. 7, figs. 2-5.

Hemiaulus sp. A. [Plate I, figs. 11-12, Plate III, figs. 1-2]

Hemiaulus sp. cf. H. polymorphus Grunow 1884: 14; Schmidt et al. 1875-1959: Tab. 143, figs. 11-13, 30-34. [Plate II, figs. 8, 9]
Hemiaulus sporalis Strelnikova 1971: 48, Tab. 3, figs. 1-10; Strelnikova 1974: 95-96, Tab. 41, figs. 1-10; Tab. 42, figs. 1-11; Hajós and Stradner 1975: 932, Pl. 29, figs. 5, 6; Harwood 1988: 84, figs. 15.7-10. [Plate V, fig. 7]

Hemiaulus tumidicornis Strelnikova 1971: 49, Tab. I, figs. 14-16; Strelnikova 1974: 102, Tab. 47, figs. 17-25; Barron 1985: Pl. 10.2, fig. 5-6; Dell'Agnese and Clark 1994: 38, fig. 4.4; Hemiaulus sp. cf. H. tumidicornis Strelnikova in Harwood 1988: 84, figs. 14.9, 25.

Hemiaulus undulatus Jousé 1951: 38, Tab. 4, fig. 1; Strelnikova 1974: 98, Tab. 47, figs. 7-9.

Lepidodiscus elegans Witt 1886: 163, Tab. 7, fig. 6; Strelnikova 1965b: 30, Tab. III, figs. 1, 2; Strelnikova 1974: 70-71, Pl. 16, figs. 1-6.

Melosira hokaidoana? Pantocsek 1892: Bd. 3, Tab. 6, fig. 91.

Melosira? campaniensis Moshkovitz, Ehrlich et Soudry 1983: 184, figs. 7 a-e.

Meristiosolen sp. 1

Micrampula parvula Hanna 1927: 26, Pl. 3, fig. 15; Long, Fuge and Smith 1946: 109; Jousé 1951: 60, Tab. 4, fig. 8; Pterotheca (Micrampula) parvula (Hanna) Hajós et Stradner 1975: 934, Pl. 12, figs. 12-15, Pl. 37, figs. 1-4; Fenner 1985: 735, figs. 13-14.

Odontotropis carinata Grunow 1884; Undescribed form (not diatomaceous?), Kitton 1871: 171, Pl. 14, figs. 12, 13; Odontotropis? carinata Grunow 1884: 7 [59];

Odontotropis carinata Grunow, Hustedt 1930: fig. 510; Schulz 1935: 393, Tab. 1, fig. 10; Jousé et al. 1949: Vol. 2, p. 179, Tab. 69, fig. 7; Krotov and Schibkova 1959: 121, Tab. 4, fig. 1, 2; Dell'Agnese and Clark 1994: 38, fig. 4.5.

Odontotropis cristata Grunow 1884: 59, Tab. 2, fig. 23, Tab. 5, figs. 58a,b; Hustedt 1930: 858, fig. 511; Schulz 1935: 393, fig. 4; Jousé et al. 1949: vol. 2, p. 179, Tab. 69, fig. 6.

Odontotropis hyalina Witt 1886: 165, Taf. 9, fig. 2; Homann 1991: 101, Taf. 25, figs. 11-13.

Paralia crenulata (Grunow) Gleser, Paralia ornata var. crenulata Grunow 1884: 44, Tab. 5 (E), fig. 34; Melosira fausta Schmidt sensu Hanna 1927: 25, Pl. 3, fig. 11-14; Paralia crenulata (Grunow) Gleser in Gleser et al. 1992: 50, Pl. 41, figs. 1-8; Nikolaev et al. 2001: 15, Pl. 8, figs. 1-8. [Plate IV, figs. 14-15]

Paralia ornata (Grunow) Grunow ex van Heurck; Melosira ornata Grunow 1884: 95, Tab. 5 (E), fig. 30, 40; Jousé et al. 1949: Vol. 2, p. 26, Tab. 4, fig. 5, Tab. 75, fig. 15;

\section{PLATE 2}

Representative diatom assemblage of the Costopyxis antiqua Zone.

1 Gladiopsis speciosus forma speciosus (Schulz) Gersonde et Harwood, sensu lato; composite low and high focus figure, $\times 1250$; Sample C-44744, Hoodoo Dome.

2-4 Basilicostephanus sp. 1; 2, valve view, $\times 1250 ; 3-4$, girdle view, $\times 1250$, high and low focus of the same specimen; Sample C-34353, Slidre Fjord.

5,12-13 Triceratium schulzii Jousé; 5, valve view, $\times 1875$; Sample C-8593, Horton River; 12-13, valve view, $\times 1875$, high and low focus of the same specimen; Sample C-44744, Hoodoo Dome.
6-7 Costopyxis schulzii f. nuda Strelnikova; girdle view, $\times 1875$, high and low focus of the same specimen; Sample C-8690, Horton River.

8-9 Hemiaulus sp. cf. H. polymorphus Grunow; girdle view, $\times 1875$, high and low focus of the same specimen; Sample C- 44742, Hoodoo Dome.

10-11, Costopyxis antiqua (Jousé) Gleser; girdle view, 14-15 $\times 1250 ; 10-11$, high and low focus of the same specimen; Sample C-34353, Slidre Fjord; 14-15, high and low focus of the same specimen; Sample C-8590, Horton River. 

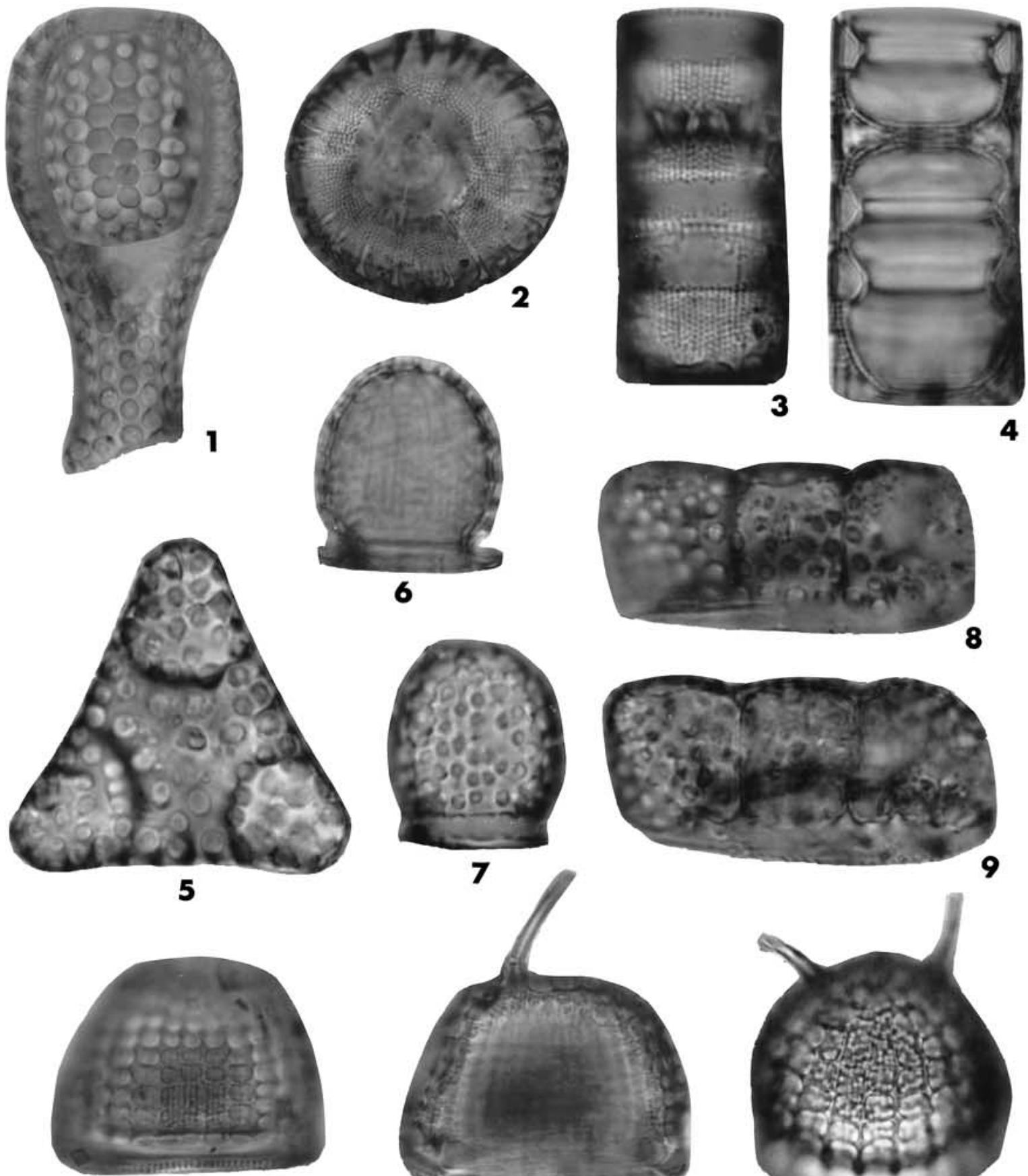

10

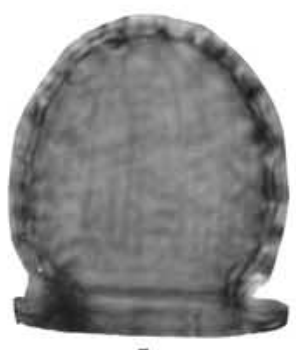

6
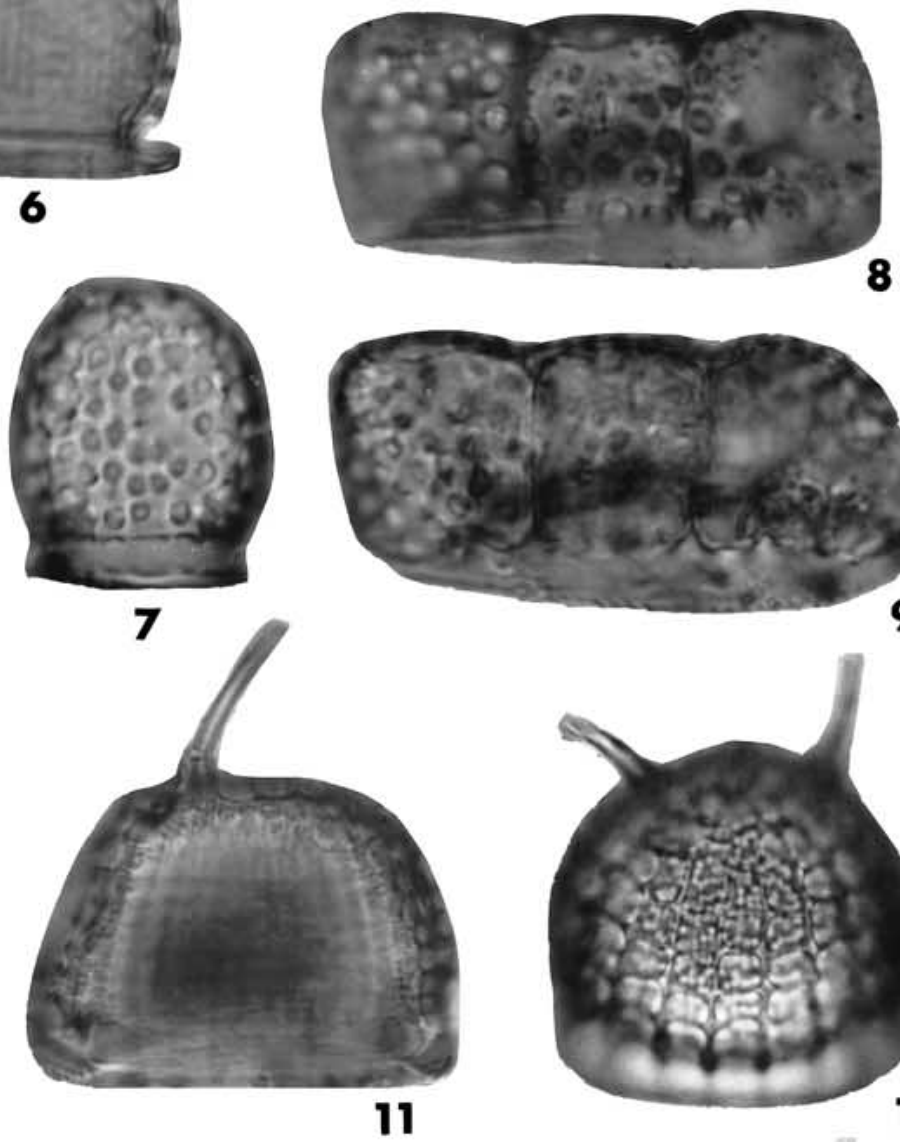

8

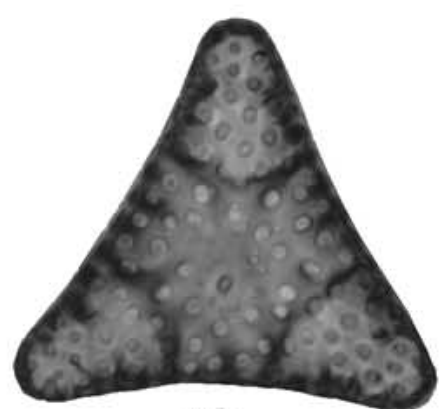

12

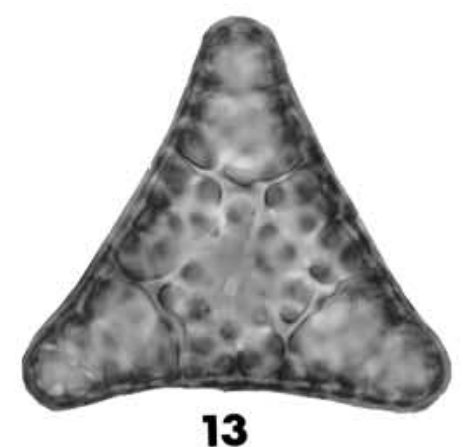

14

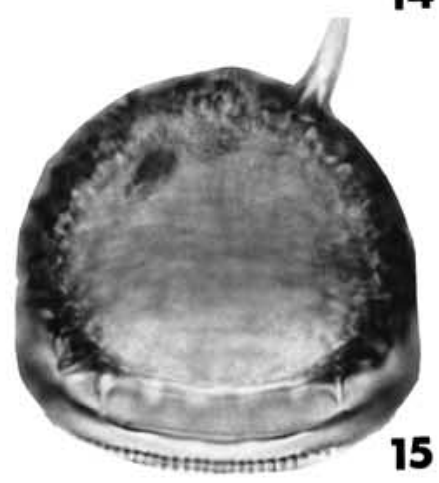


Strelnikova 1974: 47-48, Tab. 1, figs. 5, 6. [Plate I, figs. 3-4]

Paralia sulcata (Ehrenberg) Cleve; Gallionella sulcata Ehrenberg 1838: 170, Tab. 21, fig. 5; Melosira sulcata (Ehrenberg) Kützing 1844: 55, Tab. 2, fig. 7; Jousé et al. 1949: vol. 2, p. 27, Tab. 4, figs. 6a-d; Melosira sulcata var. sulcata Strelnikova 1974: 48-49, Tab. 1, figs. 9-14; Paralia sulcata (Ehrenberg) Grunow, Harwood 1988: 85, figs. 16.8-9. Diatom counts of $P$. sulcata (Ehernberg) Cleve also include counts on the species $P$. crenulata (Grunow) Gleser. [Plate IX, fig. 13]

Proboscia cretacea (Hajós et Stradner) Jordan et Priddle 1991: 56, figs. 3, 4; Rhizosolenia cretacea Hajós et Stradner 1975: 929, Pl. 7, fig. 1, Pl. 31, figs. 4-6; Barron 1985: 141, Pl. 10.3, fig. 1; Martinez-Machiavello 1987: 282, Lam. 1, fig. 1; Harwood 1988: fig. 19.8; Fenner 1991: 140, Pl. 1, figs. 4, 9; Fourtanier 1991: 201, Pl. 5, fig. 12; Dell'Agnese and Clark 1994: 38, fig. 2.12.

Pseudopodosira reticulata Strelnikova 1974: 53, Tab. 3, fig. 2.

Pseudopodosira witti (Schulz) Vekschina 1961a: 90; Strelnikova 1974: 52, Tab. 2, figs. 12-16.

Pseudopyxilla sp. cf. P. rossica (Pantocsek) Forti; Pyxilla rossica Pantocsek 1892: Bd. 3, p. 91, Tab. 19, fig. 247; Jousé et al. 1949: Vol. 2: 200, Tab. 97, fig. 7; Pseudopyxilla rossica (Pantocsek) Forti 1909: 14, Tab. 1, fig. 13; Hajós and Stradner 1975: 933, Pl. 12, figs. 1-2; Pl. 27, fig. 9; Harwood 1988: 86, figs. 17.28-29; Nikolaev et al. 2001: 24, Pl. 35, fig. 1-2. [Plate IX, figs. 7-8]

Pterotheca aculeifera Grunow ex van Heurck 1880-1885: Tab. 83, figs. 13-14, Tab. 83 bis, fig. 5; Jousé et al. 1949: vol. 2, p. 202, Tab. 75, figs. 4a-b; Jousé 1951: 59, Tab. 4, figs. 5a-b; Strelnikova 1974: 114, Tab. 57, figs. 1-26; Harwood 1988: 86, figs. 18.3-4.

Pterotheca cretacea Hajós et Stradner 1975: 934, Pl. 12, figs. 16-18, 21; Pl. 26, fig. 1; Harwood 1988: 86, figs. 18.9-11.

Pterotheca pokroskajae Jousé 1951: 58, fig. 2; Harwood 1988: 86, fig. 18.19-23.

Pterotheca sp. cf. P. spada Tempère et Brun 1889; Pterotheca spada Tempère et Brun in Brun and Tempère 1889: Tab. 1, fig. 7; Schulz 1935: 395, figs. 7a,b; Jousé et al. 1949: vol. 2, p. 203, Tab. 75, figs. 8a-d; Harwood 1988: 87, figs. 18.24-25. [Plate VIII, figs. 7, 9]

Raphoneis elliptica Jousé 1951a: Tab. 4, fig. 6.

Sceptroneis gracilis Hajós in Hajós and Stradner 1975: 936, fig. 19.

Sceptroneis grunowi Anissimova 1938; Jousé et al. 1949: Vol. 2, p. 217; Jousé 1951: 41, Pl. 4, fig. 8; Hajós and Stradner 1975: 936, Pl. 11, figs. 14, 15; Schrader and Fenner 1976: 998, Pl. 22, figs. 26-28, Pl. 23, fig. 8, Pl. 25, figs. 7, 9; Harwood 1988: 87, figs. 17.9-10.
Sheshukovia excavata (Heiberb) Nikolaev et Harwood in Nikolaev et al. 2001: 21, Pl. 29, figs. 1-5; Trinacria excavata Heiberg 1863: 51, Tab. IV, fig. 9; Hanna 1927: 37, Pl. 5, fig. 6; Harwood 1988: 89, figs. 21.15-16; Triceratium excavatum (Heiberg) Strelnikova 1974: 82-83, Tab. 31, figs. 7-14; Hajós and Stradner 1975: 932, Pl. 10, fig. 1;

Sheshukovia sp. 1; Triceratium exornatum Greville sensu Strelnikova 1974: 85, Tab. 35, figs. 1-3; Triceratium cristatum Pantocsek, Hajós and Stradner 1975: 929, Pl. 8, figs. 11-12. [Plate IV, figs. 7-10]

Spore \# 3. [Plate IX, figs. 1-2]

Spore \# 4. [Plate IX, figs. 5-6]. This resting spore is very similar to Spore \# 3, the main difference is that this form is smaller and has shorter lateral expansions.

Spore \# 12. [Plate VIII, figs. 5-6]

Stellarima stenyi (Hanna) Hasle et Sims 1986; Coscinodiscus stenyi Hanna 1927: 19, Pl. 2, figs. 5, 6; Long, Fuge and Smith 1946: 105; Coscinodiscus symbolophorus Grunow, Strelnikova 1974: 63-64, Tab. 12, figs. 1-7; Stellarima stenyi (Hanna) Hasle et Sims 1986: 111; Sims and Hasle 1987: 230-234, figs. 1-18, 27-31; Harwood 1988: 88, figs. 20.3-4; Dell' Agnese and Clark 1994: 34, fig. 4.8; Nikolaev et al. 2001: 19, Pl. 20, figs. 1-6. [Plate VII, fig. 2]

Stephanopyxis arctica (Grunow) Strelnikova et Nikolaev; Stephanopyxis turris var. arctica Grunow 1884: 91, Tab. V, figs. 20-22; Pyxidicula arctica (Grunow) Strelnikova et Nikolaev in Gleser et al. 1988: 39, Tab. 19, figs. 1-15, Tab. 20, figs. 1-5. [Plate VI, figs. 7-8]

Stephanopyxis dissonus (Schulz) Strelnikova et Nikolaev; Coscinodiscus dissonus Schulz 1935: 387, Tab. 1, fig. 5, Jousé 1949: 72, Tab. 2, fig. 1; Jousé et al. 1949: vol. 2, p. 69, Tab. 8, fig. 10; Pyxidicula dissona (Schulz)

Strelnikova et Nikolaev in Gleser et al. 1988: 41, Tab. 22, figs. 1-8. [Plate VI, figs. 1-3]

Stephanopyxis grunowii Grove et Sturt 1988 in Schmidt et al. 1875-1959: Tab. 130, figs. 1-4; Hanna 1927: 33-34, Pl. 4, fig. 12. [Plate VII, fig. 5]

Stephanopyxis lavrenkoi Jousé in Jousé et al. 1949: 40, Tab. 10, fig. 9; Strelnikova 1974: 60, Tab. VII, fig. 7.

Stephanopyxis simonseni Hajós ex Hajós et Stradner 1975: 926, Pl. 2, figs. 7, 8; Harwood 1988: 88, fig. 19.24. [Plate VIII, figs. 1-2, 8; Plate IX, figs. 3-4]

Stephanopyxis sp. A. [Plate I, figs. 13-14]

Stephanopyxis superba (Greville) Grunow 1884: 39; Hajós and Stradner 1975: 926, Pl. 2, figs. 11, 12; Harwood 1988: 88, fig. 19.25; Creswellia superba Greville 1861: 68, P1. 8, figs. 3-5. [Plate VI, figs. 4-5]

\section{PLATE 3}

1-2 Hemiaulus sp. A; girdle view, $\times 1875$, high and low focus of the same specimen; Sample C-34344, Slidre Fjord.

3-4 Gladiopsis speciosus f. aculeolatus Strelnikova; girdle view, $\times 1250$, high and low focus of the same specimen; Sample C-34353, Slidre Fjord.
5-8 Cortinocornus rossicus (Pantocsek) Gleser, girdle view, $\times 1250$; 5-6, high and low focus of the same specimen; Sample C-8593, Horton River; 7-8, high and low focus of the same specimen; Sample C-8597, Horton River.

9-10 Actinoptychus simbriskianus Schmidt; valve view, $\times 1250$, high and low focus of the same specimen; Sample C-8618, Horton River. 

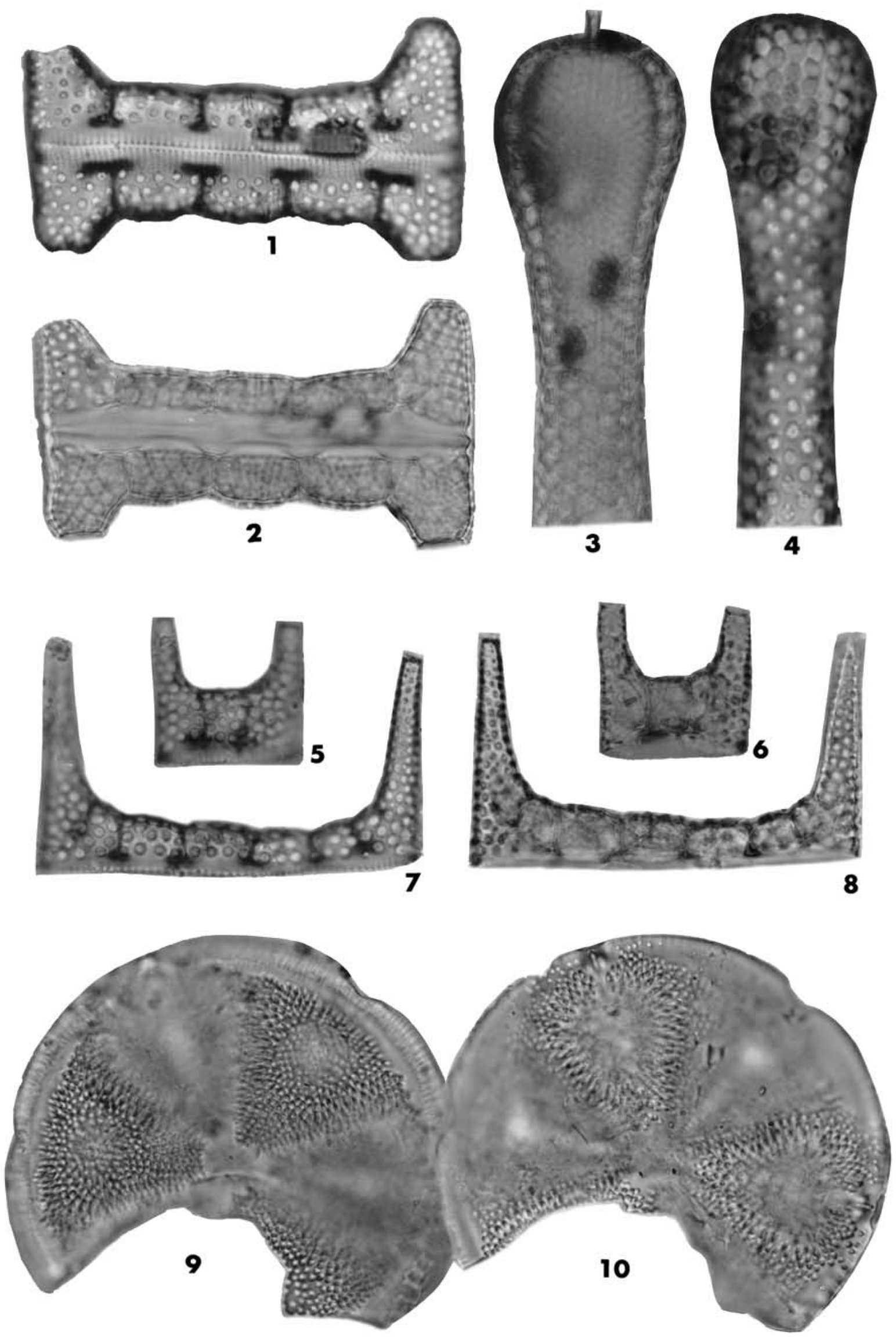
Stephanopyxis turris (Greville et Arnott) Ralfs in Pritchard 1861; Creswellia turris Greville et Arnott 1857: 538, Tab. 14, fig. 109; Stephanopyxis turris (Greville et Arnott) Ralfs in Pritchard 1861: 826, Tab. 5, fig. 74; Schulz 1935: 397; Jousé et al. 1949: vol. 2, p. 40, Tab. 10, fig. 3; Hajós and Stradner 1975: 926, Pl. 1, figs. 13-15; Barron 1985: Pl. 10.3, fig. 5; Harwood 1988: 88, figs. 19.26-27; Dell'Agnese and Clark 1994: 38, fig. 5.1; Nikolaev et al. 2001: 14, Pl. 7, figs. 5-6; Stephanopyxis turris (Greville et Arnott) Ralfs var. turris Strelnikova 1974: 59, Tab. 8, figs. 1-13. [Plate IX, figs. 9-10]

Strelnikovia antiqua (Strelnikova) Ross et Sims 1985: 326-327, Pl. 20, figs. 1-6; Pl. 21, figs. 1-7; Pl. 33, fig. 1; Rutilaria antiqua Strelnikova 1964: 230, Tab. 2, figs. 1a-e; Strelnikova 1974: 109, Tab. 53, figs. 1-3. [Plate IV, figs. 3-4]

Thalassiosiropsis wittiana (Pantocsek) Hasle ex Hasle et Syvertsen 1985: 89-90, Pl. 1-5; Harwood 1988: 89, fig. 20.6; Nikolaev et al. 2001: 12, Pl. 1, figs. 1-4; Coscinodiscus lineatus Ehrenberg, Strelnikova 1974: 62, Tab. 9, figs. 3-12; Hajós and Stradner 1975: 927, Pl. 3, figs. 1-3; Pl. 38, fig. 1. [Plate IV, fig. 13; Plate VII, fig. 6]

Triceratium indefinitum (Jousé) sensu Strelnikova 1974: 82, Pl. 30, figs. 18-22 (only). Non Trinacria indefinita Jousé 1951.

Triceratium kolbei Hustedt 1930 in Schmidt et al. 1875-1959: Taf. 372, fig. 4; Strelnikova 1974: 86, Pl. 33, fig. 14; Pl. 34 , figs. $1-4$.

Triceratium planum Strelnikova 1974: 87, Tab. 29, figs. 12-17; Barron 1985: Pl. 10.3, fig. 7; Fenner 1985: 741, figs. 13.8-9; Dell'Agnese and Clark 1994: 38, fig. 4.10.

Triceratium schulzii Jousé 1949: 72, Tab. 1, fig. 8; Strelnikova 1974: 81, Tab. 29, figs. 1-7; Hajós and Stradner 1975: 930, Pl. 8, figs. 1-2; Pl. 33, fig. 2; Fourtanier 1991: Pl. 5, fig. 6. [Plate II, figs. 5, 12-13]

Triceratium synicum Strelnikova 1965: 34, Tab. V, fig. 5, Tab. VI, figs. 1-2; Strelnikova 1974: 85, Tab. 34, fig. 5; Tab. 35, figs. 6-8.

Trinacria acutangulum (Strelnikova) Barron 1985; Triceratium acutangulum Strelnikova 1974: 83-84, Tab. 32, figs. 1-10; Trinacria acutangulum (Strelnikova) Barron 1985: 141, Pl. 10.3, figs. 6, 8, 9; Harwood 1988:
89, figs. 21.8-10, 12; Dell'Agnese and Clark 1994: 38, figs. 4.10-11. [Plate V, figs. 9-11]

Trinacria aries Schmidt 1886 in Schmidt et al. 1875-1959: Taf. 96, figs. 14-17; Taf. 150, figs. 14, 15; Hanna 1927: 36, Pl. 5, figs. 1, 2; Hajós and Stradner 1975: 932, Pl. 9, figs. 9-11, Pl. 33, fig. 5; Harwood 1988: 89, fig. 21.14; Nikolaev et al. 2001: 21, Pl. 25, figs. 4-6.

Trinacria coronatum (Witt) Strelnikova 1974: 89, Tab. 34, figs. $1-4$.

Trinacria indefinita Jousé 1951: 50, Tab. 2, figs. 5a,b; Triceratium indefinitum (Jousé) Strelnikova 1974: 82, Tab. 30, figs. 1-29, Tab. 31, figs. 1-6; Harwood 1988: 89, figs. 20.11, 21.4-7; Dell'Agnese and Clark 1994: 38, fig. 5.3. [Plate IV, figs. 1-2, 5-6]

Trinacria tessela Krotov 1959: 108-109, fig. 5; Trinacria tessela (Krotov) Strelnikova 1974: 84, Tab. 74, figs. 8-11; Barron 1985: 141, Pl. 10.3, fig. 10.

Trochosira denticulatum (Strelnikova) Tapia, nov. comb. Basionym: Sceletonema denticulatum Strelnikova 1974: 54, Tab. 1, fig. 3. Non Trochosira spinosa Kitton in Gleser et al. 1992: 68, Tab. 57, figs. 1, 2. [Plate I, figs. 5, 6]

Trochosiropsis polychaeta (Strelnikova) Tapia, nov. comb. Basionym: Sceletonema polychateum Strelnikova 1971: 42, Tab. 1, figs. 3-5. Synonyms: Sceletonema polychaetum Strelnikova in Strelnikova, 1974: 54, Tab. 3, figs. 3-7; Barron, 1985: Pl. 10.1, figs. 2-4; (?) Pyrgodiscus triangulatus Hajós et Stradner, 1975: 928, figs. 11a,b, Pl. 18, figs. 5, 6; Trochosira polychaeta (Strelnikova) Sims, 1988: 251-253, figs. 15-21, 29-34. [Plate VIII, figs. 3-4]

\section{REFERENCES}

ABBOTT, W. H., 1978. Cretaceous diatoms from the Peedee Formation of South Carolina. Geologic Notes, 22(2): 105-108.

ANISSIMOVA, N., 1938. Diatomovye nizhnego Paleogena (Srednee Povolzhe). Leningrad.

BALLANCE, P. F., BARRON, J. A., BLOME, C. D., BUKRY, D., CAWOOD, P. A., CHAPRONIERE, G. C. H., FRISCH, R., HERZER, R. H., NELSON, C. S., QUINTERO, P., RYAN, H., SCHOOL, D. W., STEVENSON, A. J., TAPPIN, D. G. and VALLIER, T. L., 1989. Late Cretaceous pelagic sediments, volcanic

\section{PLATE 4}

Representative diatom assemblage of the Trinacria indefinita Zone.

1-2,5-6 Trinacria indefinita Jousé; 1-2, valve view, $\times 1250$, low and high focus of the same specimen; Sample C-8602, Horton River; 5-6, valve view, $\times 1875$, low and high focus of the same specimen; Sample C-8599, Horton River.

3-4 Strelnikovia antiqua (Strelnikova) Ross et Sims; valve view, $\times 1250$, high and low focus of the same specimen; Sample C-8597, Horton River.

7-10 Sheshukovia sp. 1, valve view, $\times 1250$; 7-8, low and high focus of the same specimen; Sample C-8595, Horton River; 9-10, low and high focus of the same specimen; Sample C-8599, Horton River.
11-12 Hemiaulus antiquus Jousé; girdle view, ×1875, high and low focus of the same specimen; Sample C-8600, Horton River.

13 Thalassiosiropsis wittiana (Pantocsek) Hasle, valve view, ×750; Sample C-8597, Horton River.

14-15 Paralia crenulata (Grunow) Gleser; valve view, $\times 1250$, high and low focus of the same specimen; Sample C-8599, Horton River. 

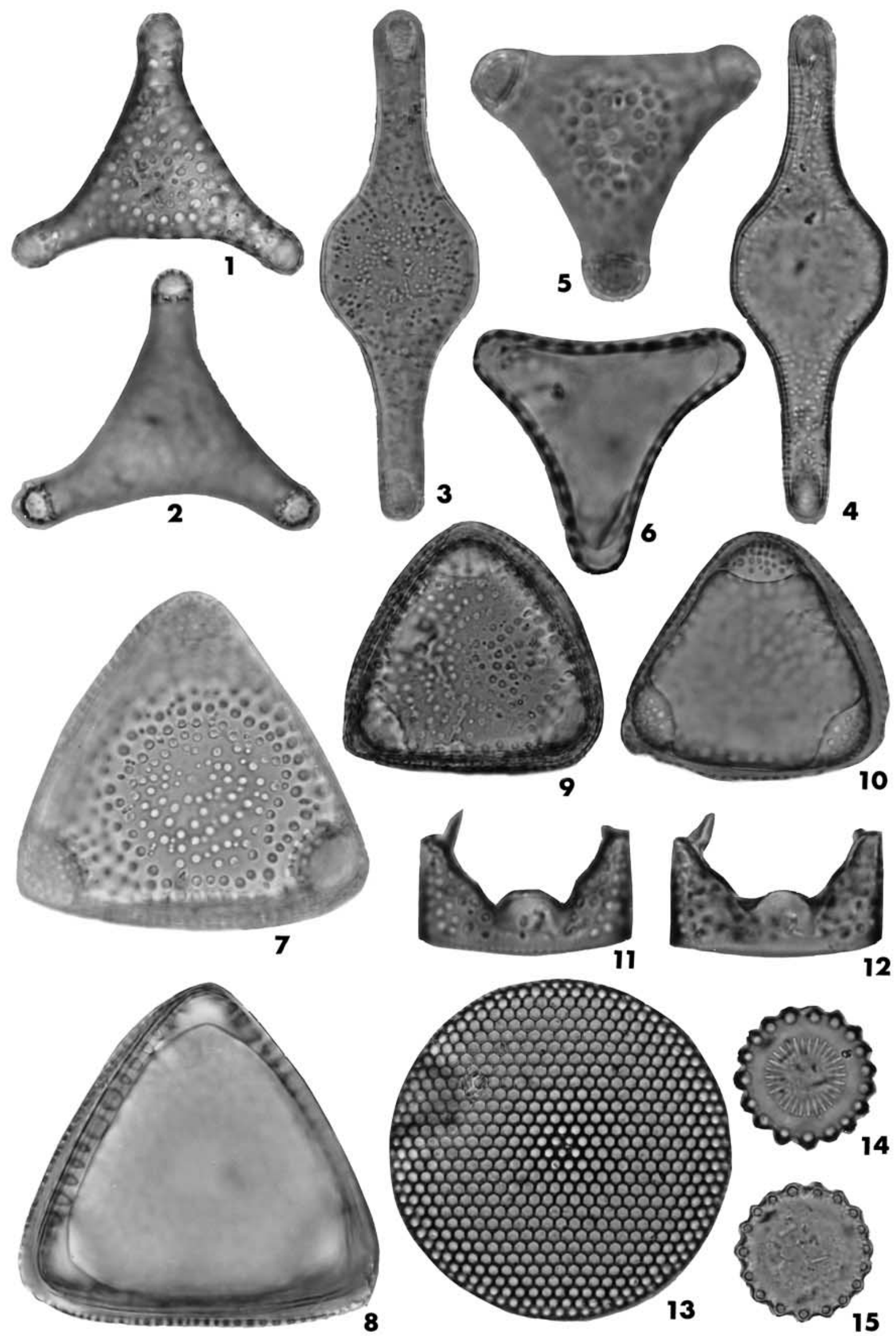
ash and biotas from the near Louisville hotspot, Pacific Plate, Paleolatitude $\sim 42^{\circ} \mathrm{S}$. Paleogeography, Paleoclimatology, Paleoecology, 71:281-299.

BARKER, J. W. and MEAKIN, S. H., 1944. New and rare diatoms. Journal of the Quekett Microscopical Club, Series 4, 2(1): 18-22, Pl. 3,4.

, 1945. New and rare diatoms. Journal of the Quekett Microscopical Club, Series 4, 2(2): 76-79, Pl. 15,16.

1946. New diatoms from the Moreno Shale. Journal of the Quekett Microscopical Club, Series 4, 2(3): 143-144, Pl. 22.

, 1948. New and rare diatoms. Journal of the Quekett Microscopical Club, Series 4, 2(5): 233-235, Pl. 28.

, 1949. New and rare diatoms. Journal of the Quekett Microscopical Club, Series 4, 2(6): 301-303, Pl. 37, 38.

BARRON, J. A., 1985. Diatom biostratigraphy of the CESAR 6 Core, Alpha Ridge. In: H. R. Jackson, P. J.Mudie and S. M. Blasco (Editors). Initial Geological Report on CESAR. The Canadian Expedition to study the Alpha Ridge, Arctic Ocean. Geological Survey of Canada, Paper 84-22: 137-148.

BARRON, J. A. and BALDAUF, J. G., 1995. Cenozoic marine diatom biostratigraphy and applications to paleoclimatology and paleoceanography. In: C. D. Blome, et al. (Convenors). Siliceous Microfossils. Paleontological Society Short Courses in Paleontology, 8: 107-118.

BERGSTRESSER, T. J. and KREBS, W. N., 1983. Late Cretaceous (Campanian-Maastrichtian) diatoms from the Pierre Shale, Wyoming, Colorado and Kansas. Journal of Paleontology, 57(5): 883-891, 7 figs.

BLAKWILL, H. R., 1974. Structure and stratigraphy, Ringnes Islands and nearby smaller islands, District of Franklin. Geological Survey of Canada, Paper 74-1, Part A: 287-289.

BLAKWILL, H. R. and HOPKINS, W. S. Jr., 1976. Cretaceous stratigraphy, Hoodoo Dome, Ellef Ringnes Island, District of Franklin. Geological Survey of Canada, Paper 76-1B: 329-334.

BRIGGER, A. L. and HANNA, G., 1965. A review of Kittonia, a genus of diatoms. Occasional Papers of the California Academy of Science, (50): 1-10.
BRUN, J. and TEMPÈRE, J., 1889. Diatomées fossiles du Japon. Espèces marines \& nouvelles des calcaires argileux de Sendaï \& de Yedo. Mémoires de la Société de Physique et d'Histoire Naturelle de Genéve, 30(9): 1-75,

CANDE, S. C. and KENT, D. V., 1992. A new geomagnetic polarity time scale for the Late Cretaceous and Cenozoic. Journal of Geophysical Research, 97(B10): 13917-13951.

DEFLANDRE, G., 1941. Sur la présence de diatomés dans certains silex creux Turoniens et sur un nouveau mode de fossilisation de ces organismes. Comptes Rendus de l'Académie des Sciences de Paris, 213: 878-880.

DELL'AGNESE, D. J., 1988. Cretaceous and Eocene diatoms, silicoflagellates, archaeomonads and ebridians from the Arctic Ocean: Core FL-437 and FL-422. Unpublished Thesis, Master of Science, Geology, University of Wisconsin at Madison, $139 \mathrm{pp}$.

DELL'AGNESE, D. J. and CLARK, D. L., 1994. Siliceous microfossils from the warm Late Cretaceous and early Cenozoic Arctic Ocean. Journal of Paleontology, 68(1): 31-47.

EHRENBERG, C. G., 1838. Die Infusionsthierchen als vollkommende Organismen. Ein Blick in das tiefere organische Leben der Natur. Leipzig, 548 pp., 64 Taf.

1844. Eine Mitteilung über 2 neue Lager von Gebirgsmassen aus Infusorien als Meers-Absatz in Amerika und eine Vergleichung derselben mit den organischen Kreide-Gebilden in Europa und Afrika. Berichte der Berliner Akademie, pp. 57-97.

, 1854. Mikrogeologie. Leipzig, 374 pp., 40 Taf.

EMBRY, A. F., 1991. Mesozoic history of the Arctic Islands, Chapter 14 Geological Society of America. The Geology of North America, Vol. E: $371-433$

FENNER, J., 1982. Cretaceous diatoms off New Jersey. 7th Int. Symp. Living and Fossil Diatoms, Philadelphia (Abstracts).

1985. Late Cretaceous to Oligocene planktic diatoms In: J. Saunders, H. M. Bolli and K. Perch-Nielsen, Eds., Plankton Stratigraphy. Cambridge University Press. pp. 713-762.

, 1991. Taxonomy, stratigraphy, and paleoceanographic implications of Paleocene diatoms. Proceedings of the Ocean Drilling Program, Scientific Results. College Station, TX: Ocean Drilling Program, 114: 123-154.

\section{PLATE 5}

1-4 Gladiopsis speciosus (Schulz) Gersonde et Harwood; $1-2$, girdle view, $\times 1250$, high and low focus of the same specimen; Sample C-44744, Hoodoo Dome; $3-4$, girdle view, $\times 1875$, high and low focus of the same specimen; Sample C-8603, Horton River.

5-6 Gladiopsis speciosus f. poratus Strelnikova; girdle view, $\times 1250$, high and low focus of the same specimen; Sample C-8600, Horton River.
7 Hemiaulus sporalis Strelnikova (resting spore); valve view, $\times 1250$. Sample C-8608, Horton River.

8 Hemiaulus polymorphus var. frigida Grunow; girdle view, ×1875; Sample C-8602, Horton River.

9,10-11 Trinacria acutangula (Strelnikova) Barron; 9, girdle view, ×1250; Sample C-8603, Horton River; 10-11, valve view, $\times 1250$, low and high focus of the same specimen; Sample C-8599, Horton River. 


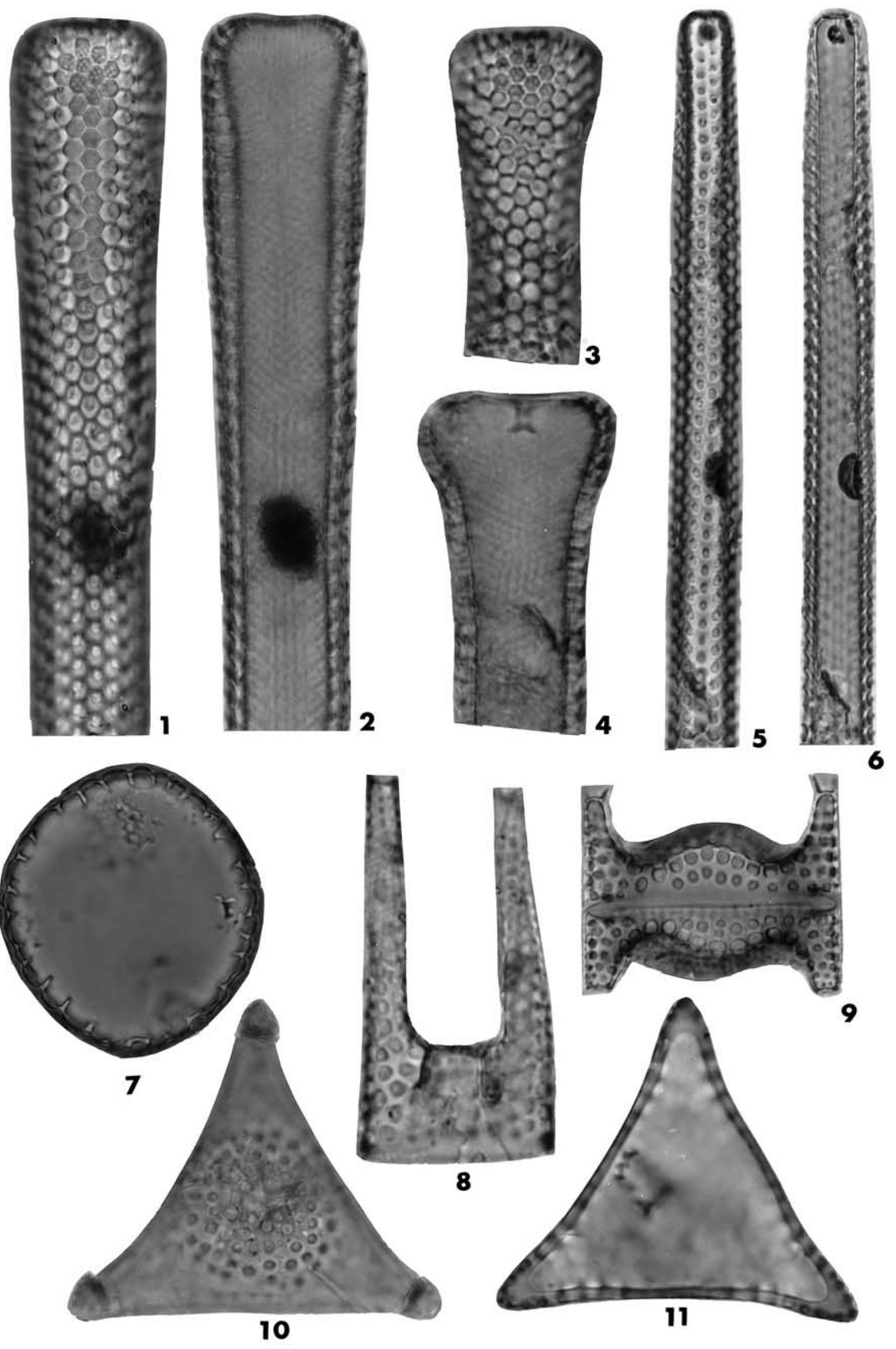


FORTI, A., 1909. Studi per una monographia del genere Pyxilla (Diatomee) e dei generi affini. La Nuova Notarisia, 20(12): 5-24.

FOULCAULT, A., SERVANT-VILDARY, S., FANG, N. and POWICHROWSKI, L., 1986. Un des plus anciens gisements de diatomées découvert dans l'Albien-Cenomanien inférieur des Alpes ligures (Italie). Remarques sur l'apparition de ces alges. Comptes Rendus de l'Académie des Sciences de Paris, Série II, 303(5): 397-402.

FOURTANIER, E., 1991. Diatom biostratigraphy of Equatorial Indian Ocean Site 758. Proceedings of the Ocean Drilling Program, Scientific Results. College Station, TX: Ocean Drilling Program, 121: 189-208.

GERSONDE, R. and HARWOOD, D. M., 1990. Lower Cretaceous diatoms from ODP Leg 113, Site 693 (Weddell Sea). Part 1: Vegetative cells. In: Barker, P. F. et al., Eds., Proceedings of the Ocean Drilling Program, Scientific Results. College Station, TX: Ocean Drilling Program, 113: 365-402.

GIVEN, M. M. and WALL, J. H., 1971. Microfauna from the Upper Cretaceous Bearpaw Formation of south-central Alberta. Canadian Petroleum Geology, Bulletin, 19(2): 502-544.

GLESER, S. I., 1984. "Significance of research on the systematics of diatoms for biostratigraphy and paleogeography". Ezhedognik Vsesoyuznog Paleontologicheskogo Obshchestva, 27: 284-298. (In Russian).

GLESER S. I, MAKAROVA I. V, MOISSEEVA, A. I. and NIKOLAEV, V. A., 1988. The Diatoms of the USSR. Fossil and Recent. Vol. II, Fasc. 1. Pyxidiculaceae, Thalassiosiropsidaceae, Triceratiaceae, Thalassiosiraceae. Nauka, Leningrad, 124 pp.

1992. The Diatoms of the USSR. Fossil and Recent. Vol. II, Fasc. 2. Stephanodiscaceae, Ectodictyonaceae, Paraliaceae, Radialiplicataceae, Pseudopodosiraceae, Throchorosiraceae, Melosiraceae, Aulacosiraceae. Nauka, St. Petersburg, 125 pp.

GRESHAN, C. W., 1985. Cretaceous and Paleogene siliceous phytoplankton assemblages from DSDP Sites 216, 214 and 208 in the Pacific and Indian Oceans. Unpublished Thesis, Master Science, Geology, University of Wisconsin at Madison, $233 \mathrm{pp}$.

1986. Cretaceous and Paleogene siliceous phytoplankton assemblages from DSDP Sites 216, 214 and 208 in the Pacific and Indean Oceans. North-Central Sect. Meeting, Geological Society of America, Kent, Ohio. GSA Abstract with Programs, 18(4): 290.
GREVILLE, R. K., 1861. Descriptions of new and rare diatoms. Series II. Transactions of the Royal Microscopical Society of London, N. S., 9: 67-73, Pl. VIII.

1865. Descriptions of new and rare diatoms. Series XV. Transactions of the Royal Microscopical Society of London, N. S., 13: 24-34, Pl. III-IV.

GREVILLE, R. K. and ARNOTT, G. A. W., 1857. In: Gregory, W. On new forms of marine diatomaceae found in the Firth of Clyde and in Loch Fyne. Transactions of the Royal Society of Edinburgh, 21: 473-542.

GRUNOW, A., 1884. Die Diatomeen von Franz Josefs-Land. Denkschriften der mathematisch-naturwissenschaftlichen Classe der Kaiserlichen Akademie der Wissenschaften, 48: 53-112, 5 Taf.

HAJÓS, M. and STRADNER, H., 1975. Late Cretaceous Archaeomonadaceae, Diatomaceae and Silicoflagellatae from the South Pacific Ocean, Deep Sea Drilling Project, Leg 29, Site 275. In: Kennett, J. P, Houtz, R. E., Eds., Initial Reports Deep Sea Drilling Project. Washington, DC: US Government Printing Office, 29: 913-1009.

HANNA, G D., 1927. Cretaceous diatoms from California. Occasional Papers of the California Academy Science, 13: 5-49, Pl. 1-5.

1934. Additional notes on diatoms from the Cretaceous of California. Journal of Paleontology, 8(3): 352-355, Pl. 48.

HARWOOD, D. M., 1988. Upper Cretaceous and lower Paleocene diatom and silicoflagellate biostratigraphy of Seymour Island, Eastern Antarctic Peninsula. In: R. Feldmann and M. O. Woodburne, Eds., The Geology and Paleontology of Seymour Island. Geological Society of America, Memoir, 169: 55-129.

HARWOOD, D. M. and NIKOLAEV, V. A., 1995. Cretaceous Diatoms: Morphology, Taxonomy, Biostratigraphy. In: C. D. Blome, P. M. Whalen, and K. M. Reed (Convenors). Siliceous Microfossils. Paleontological Society Short Courses in Paleontolology, 8: 81-106.

HASLE, G. R. and SIMS, P. A., 1986. The diatom genera Stellarima and Symbolophora with comments on the genus Actinoptychus. British Phycological Journal, 21: 97-114.

HASLE, G. R. and SYVERTSEN, E. E., 1985. Thalassiosiropsis, a new diatom genus from the fossil records. Micropaleontology, 31: 82-91.

HEIBERG, P. A. C., 1863. Conspectus criticus diatomacearum Danicarum. Wilhem Priors Forlag, Kjobenhavn, 135 pp., 6 Tabs.

\section{PLATE 6}

1,2-3 Stephanopyxis dissonus (Schulz) Strelnikova et Nikolaev; 1 , internal valve view, $\times 1250$, low and high focus; Sample C-8597, Horton River; 2-3, girdle view, low and high focus of the same specimen; Sample C8621, Horton River.

45 Stephanopyxis superba (Greville) Grunow; internal valve view, $\times 1250 ; 4$, high and low focus of the same specimen; Sample C-8618, Horton River; 5, high focus; Sample C-8603, Horton River.
6 Costopyxis reticulata (Long, Fuge et Smith) Gleser; valve view, low and high focus, $\times 1250$; Sample C-8610, Horton River.

7-8 Stephanopyxis arctica (Grunow) Strelnikova et Nikolaev; girdle view, $\times 1250$, high and low focus of the same specimen; Sample C-8600, Horton River. 


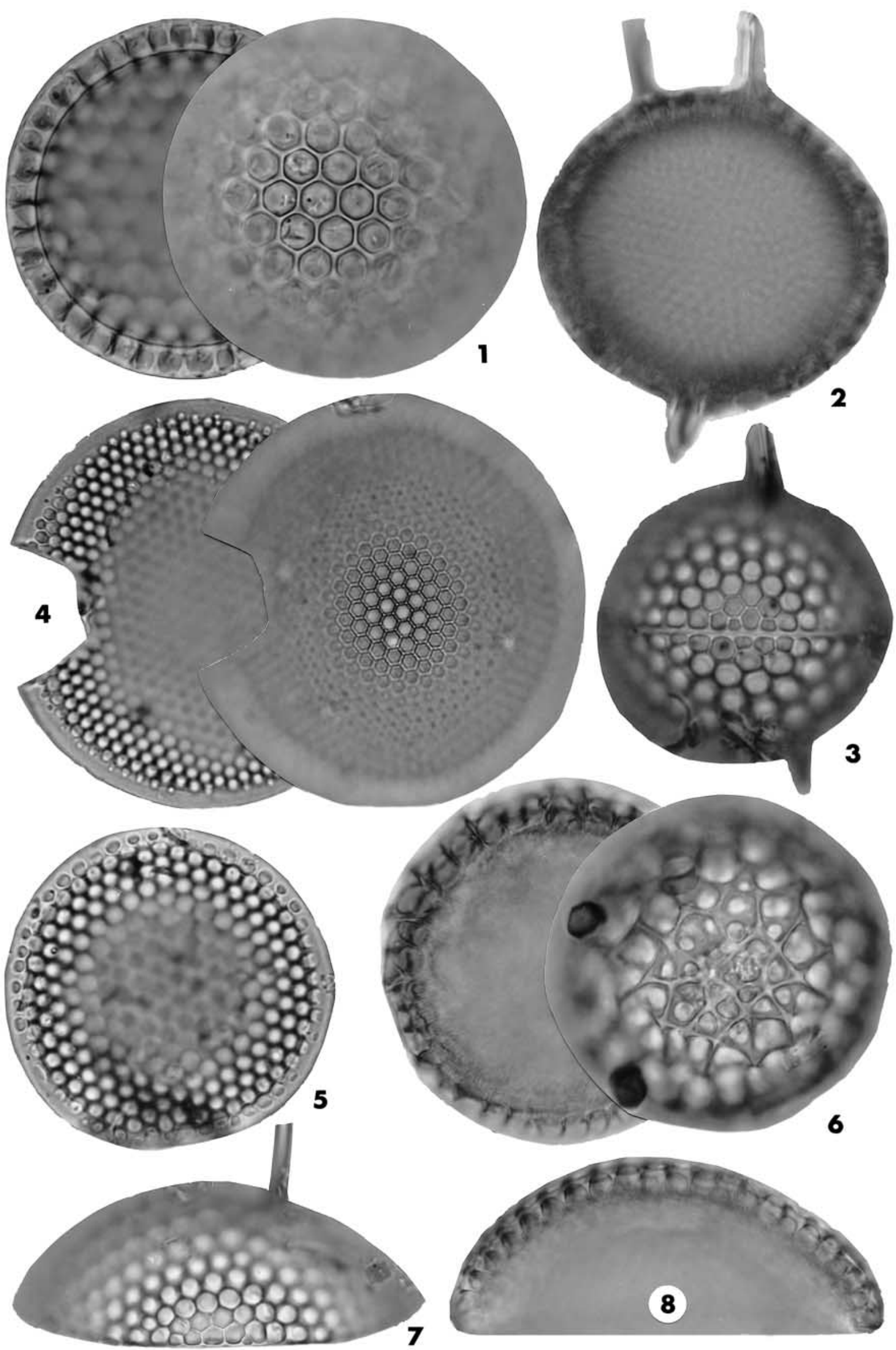


HEURCK, H. VAN, 1880-1885. Synopsis des Diatomées de Belgique. Ducaju et Cie., Anvers, 355 pp, 135 Pl.

HOMANN, M. 1991. Die diatomeen der Fur-Formation (Alttertertiär) aus dem Limfjord-Gebiet, Nordjütland/Dänemark. Geologische Jahrbuch, Reihe A, Heft 123: 1-285.

HUBER, B. T. and WATKINS, D. K., 1992. Biogeography of Campanian-Maastrichtian calcareous nannoplankton in the Region of the Southern Ocean: Paleogeographic and paleoclimatic implications. In: Kennett, J. P. and Warnke, D. A., Eds., The Antarctic Paleoenvironment: A Perspective on Global Change. Antarctic Research Series, American Geophysical Union 56: 31-60.

HUSTEDT, F., 1930. Die Kieselalgen Deutschlands, Österreichs und der Schweiz mit Berücksichtigung der übrigen Länder Europas sowie der angrenzenden Meeresgebiete. In: L. Rabenhorsts's Kryptogamen Flora von Deutschland, Österreich und der Schweiz. Bd. 7, Teil 1, Lief. 5, pp. 785-920. Akademische Verlagsgesellschaft m. b. H., Leipzig.

JORDAN, R. W. and PRIDDLE, J., 1991. Fossil members of the diatom genus Prosbocia. Diatom Research, 6(1): 55-61.

JOUSÉ, A. P., 1948. "Pre-Tertiary diatom algae". Botanicheskii Zhurnal SSSR, 33(3): 345-356. (In Russian).

1949. Algae diatomaceae aetatis supernecretaceae ex arenis argillaceis systematis fluminis Bolschoy Aktay in declivitate orientali Ural Borealis. Botanicheskie Materialy, Otdela Sporovykh Rastenii, Botanicheskii Institut, Akademia Nauk SSSR, 6: 65-78. (In Russian).

1951. Diatomeae et silicoflagellatae aetatis cretae superne e Montibus Uralensis Septentrionalibus. Botanicheskie Materialy, Otdela Sporovykh Rastenii, Botanicheskii Institut, Akademia Nauk SSSR, 7: 42-65. (In Russian).

1955. Species novae generis Gladius Schulz in stratura aetatis cretaceae superioris. Botanicheskie Materialy, Otdela Sporovykh Rastenii, Botanicheskii Institut, Akademia Nauk SSSR, 10: 72-76. (In Russian).

JOUSÉ, A. P., KISILEV, A. I., PORETSKII, V. S.., PROSHKINA-LAVRENKO, A. I. and SHESHUKOVA, V. S., 1949. "Diatom Analysis. Vol. 2. Description of fossil and Recent diatoms. Orders Centrales and Mediales". Gosudartstvennoe Izdate'stvo Geologicheskoi Literatury, 238 pp., 101 Tabs. (In Russian).
KENT, D. V. and GRADSTEIN, F. M., 1985. A Cretaceous and Jurassic geochronology. Geological Society of America Bulletin, 96: 1419-1427, 3 figs., 2 tables.

KITCHELL, J. A., 1980. Late Cretaceous and Paleocene diatoms from the Central Arctic Ocean Sixth International Symposium on Living and Fossil Diatoms, Budapest (Abstracts).

KITTON, F., 1870-71. On diatomaceous deposits from Jutland. Journal of the Quekett Microscopical Club, 2: 99-102, 168-171, 5 Pls.

KOUTSOUKOS, E. A. M. and HART, M. B., 1990. Radiolarians and diatoms from the mid-Cretaceous succesions of the Sergipe Basin, Northeastern Brazil: paleoceanography assessment. Journal of Micropalaeontology, 9(1): 45-64.

KROTOV, A. I., 1957a. "Diatomaceous algae from the Upper Cretaceous and Paleogene deposits on the eastern slopes of the Urals and Transurals". In: Proceedings of the Interdepartmental Conference on the developments in Stratigraphy. Siberia. Leningrad, Gostoptekhizdat, pp: 298-302. (In Russian)

1957b. "The stratigraphy of the Upper Cretaceous and the Paleogene deposits of the eastern slope of the North and Middle Urals based on the diatom algae data". Trudy Gorno-geologischeskogo, Inst. Uralisk., Akad. Nauk SSSR, 28(4): 17-38. (In Russian)

1959. Species novae diatomacearum e sedimentis cretae superioris in montibus Uralensibus. Botanicheskie Materialy, Otdela Sporovykh Rastenii, Botanicheskii Institut, Akademia Nauk SSSR, 12: 106-112. (In Russian).

KROTOV, A. I. and SCHIBKOVA, K. G., 1959. Species novae Diatomacearum e Paleogeno Montium Uralensium. Botanicheskie Materialy, Otdela Sporovykh Rastenii Botanicheskii Institut, Akademia Nauk SSSR, (Notulae Systematicae e Sectione Cryptogamica Instituti Botanici Nomine V. L. Komarovii Academiae Scientarum URSS), 12: 112-129. (In Russian).

1961. "Complexes of diatoms and silicoflagellate algae in the Upper Cretaceous, Paleogene, and Neogene deposits of the Eastern slope of the Urals and Transurals". Geological and Paleontological materials, mineral resources of the Urals, 9: 191-249.

KÜTZING, F. T., 1844. Die Kieselschaligen Bacillarien oder Diatomeen. Nordhausen, $152 \mathrm{pp}, 30$ Taf.

LONG, J. A., FUGE, D. P. and SMITH, J., 1946. Diatoms of the Moreno Shale. Journal of Paleontology, 20(2): 89-118.

\section{PLATE 7}

1 Actinoptychus tenuis Strelnikova; valve view, high and low focus, $\times 1250$; Sample C-8608, Horton River.

2 Stellarima stenyi (Hanna) Hasle et Sims; valve view, $\times 1250$; Sample C-8612, Horton River.

3 Aulacodiscus septus f. septus Schmidt; valve view, $\times 1250$; Sample C-8630, Horton River.

4 Actinoptychus tuberculatus Strelnikova; valve view, $\times 1250$; Sample C-8607, Horton River.
5 Stephanopyxis grunowi Grove et Sturt; valve view, $\times 1250$; Sample C-8595, Horton River.

6 Thalassiosiropsis wittiana (Pantocsek) Hasle; valve view, ×750; Sample C-8601, Horton River.

7-8 Hemiaulus echinulatus Jousé; girdle view, ×1875, high and low focus of the same specimen; Sample C-8601, Horton River. 

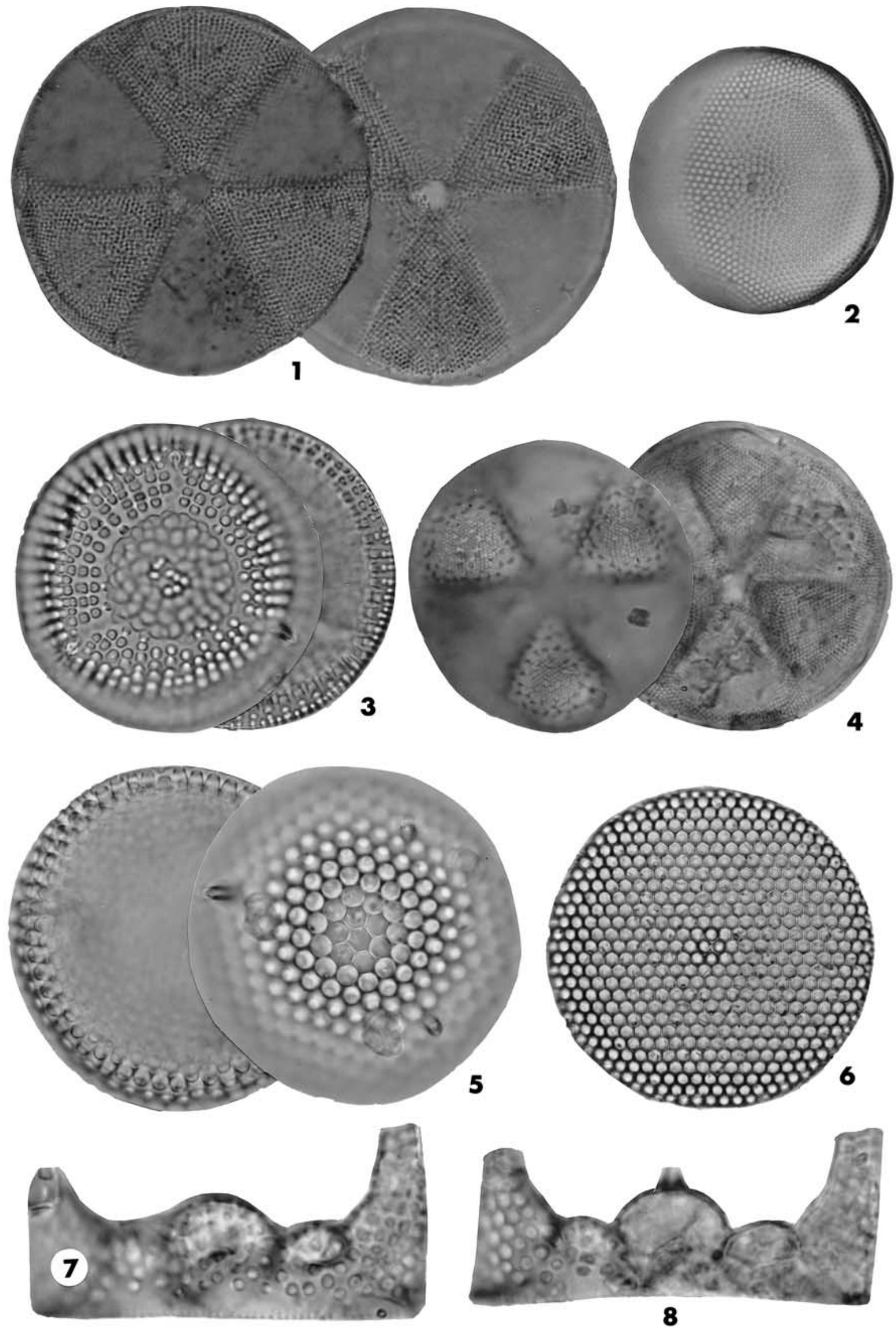
MARTINEZ-MACHIAVELLO, J. C., 1987. Bioestratigrafía diatómica de un perfil del cretácico superior de la Isla Vicecomodoro Marambio, Antártida. Ameghiniana, 24(3-4): 277-288.

MCINTYRE, D. J., 1974. Palynology of an Upper Cretaceous section, Horton River, District of Mackenzie, N.W.T. Geological Survey of Canada, Paper 74-14: 1-57.

MOSHKOVITZ, S., EHRLICH, A. and SOUDRY, D., 1983. Siliceous microfossils of the Upper Cretaceous Mishash Formation, Central Negev, Israel. Cretaceous Research, 4: 173-194.

MÜLLER, O., 1912. Diatomeenrest aus der Turonschichten der Kreide. Berichte fur Deutsche Botanische Gessellschaft, 29: 661-668.

NIKOLAEV, V. A. and HARWOOD, D. M., 2000. Morphology and taxonomic position of the Late Cretaceous diatom genus Pomphodiscus Barker and Meakin. Micropaleontology, 46(2): 167-177.

NIKOLAEV, V. A., KOCIOLEK, J. P., FOURTANIER, E., BARRON, J. A. and HARWOOD, D. M., 2001. Late Cretaceous diatoms (Bacillariophyceae) from the Marca Shale member of the Moreno Formation, California. Occasional Papers of the California Academy of Sciences, (152): 1-119.

OBRADOVICH, J. D., 1993. A Cretaceous time scale. In: W. G. E. Cadwell, and E. G. Kauffman, Eds., Evolution of the Western Interior Basin. Geological Association of Canada, Special Paper, 39: 379-396.

PANTOCSEK, J., 1886-1892. Beiträge zur Kenntnis der fossilen Bacillarien Ungarns. Theil I. Marine Bacillarien, 75 pp, 30 Taf. (1886); Theil II. Brackwasser Bacillarien. Analyse de marine depôt von Bory, Bremia, Nagy-Kürtos in Ungarn, Ananino und Kusnetzk in Russland, 123 pp., 30 Taf. (1889); Theil III. Süsswasser Bacillarien. Anhand-analysen 15 neuer depôts von Bulgarien, Japan, Mähren, Russland und Ungarn, 42 Taf. (1892). Nagy-Tapolosány, Julius Platzko.

PERCH-NIELSEN, K., 1975. Late Cretaceous to Pleistocene silicoflagellates from the southern Southwest Pacific, DSDP Leg 29. In: Kennett, J. P and Houtz, R. E., Eds., Initial Reports Deep Sea Drilling Project. Washington, DC: US Government Printing Office, 29: 677-721.

PLAUCHUT, B. P. and JUTARD, G. G., 1976. Cretaceous and Tertiary stratigraphy, Banks and Eglinton Islands and Anderson Plains (N.W.T.). Canadian Petroleum Geology, Bulletin, 24(3): 321-371.
PRITCHARD, A., 1861. A history of infusoria, living and fossil arranged according to "Die Infusionsthhierchen" of C. G. Ehrenberg. $4^{\text {th }}$ Edition. Whittaker and Col., London, 968 p. 40 pls.

RIEGRAF, W., 1995. Radiolarien, diatomeen, cephalopoden und stratigraphie im pelagischen Campanium Westfalens (Oberkreide, NW-Deutschland). Neues Jahrbuch für Geologie und Paläontologie, Abhandlungen, 197(2): 129-200.

ROSS, R. and SIMS, P. A., 1985. Some genera of the Biddulphiaceae (diatoms) with interlocking linking spines. Bulletin of the British Museum (Natural History), Botany series, 13(3): 277-381.

1997. A revision of Actinodyction Pantosek. Diatom Research, 12(2): 321-340.

RUSSELL, D. A., 1967. Cretaceous vertebrates from the Ardenson River, N.W.T. Canadian Journal of Earth Sciences, 4: 21-38.

SCHIBKOVA, K. G., 1961. "Some new data of Upper Cretaceous and Paleogene flora of the diatom algae of the Eastern slope of the Ural and Transural". In: Decisions and Proceedings of the Intraregional meeting on working out a stratigraphic scheme for the West Siberian depression. Gostoptekhizdat, Leningrad, pp. 239-243.

SCHMIDT, A. (Fortgesetzt von M. SCHMIDT, F. FRICKE, H, HEIDEN, O. MÜLLER and F. HUSTEDT), 1875-1959. Atlas der Diatomaceenkunde. Tafel 1-480. Leipzig.

SCHRADER, H.-J., 1969. Die Pennaten Diatomeen aus Obereozän von Oamaru, Neuseeland. Nova Hedwigia, Beihefte, Heft 28, 124 pp., 39 Taf.

SCHRADER, H.-J. and FENNER, J., 1976. Norwegian Sea Cenozoic diatom biostratigraphy and taxonomy. In: Talwani, M. et al. (Eds.), Initial Reports of the Deep Sea Drilling Project, 38: 921-1099.

SCHRADER, H.-J. and GERSONDE, R., 1978. Diatoms and silicoflagellates. In: W. J. Zachariasse, et al., Eds., Micropaleontological counting methods and techniques: An exercise on an $8 \mathrm{~m}$ section of the Lower Pliocene of Capo Rossello, Sicily. Utrecht Micropaleontology Bulletins, 17: 129-176.

SCHULZ, P., 1935. Diatomeen aus senonen Schwammgesteinen der Danziger Bucht. Zugleich ein Beitrag zur Entwicklungsgeschichte der Diatomeen. Botanisches Archiv, 37: 383-413.

\section{PLATE 8}

Representative diatom assemblage of the Stephanopyxis simonseni Zone.

1-2,8 Stephanopyxis simonseni Hajós; external valve view, $\times 1250 ; 1-2$, low and high focus of the same specimen; 8 , internal valve view, high and low focus, $\times 1250$; Sample C-8623, Horton River.

3-4 Trochosiropsis polychaeta (Strelnikova) Tapia; 3, girdle view, ×1250; Sample C-8612, Horton River; 4, valve view, $\times 1250$; Sample C-8623, Horton River.
5-6 Unidentified resting spore \#12; girdle view, $\times 1250$, high and low focus of the same specimen; Sample C-8615, Horton River.

7,9 Pterotheca $\mathrm{sp}$. cf. P. spada Tempère et Brun; girdle view, $\times 750$; 7, Sample C-8618, Horton River; 9, Sample C-8612, Horton River. 

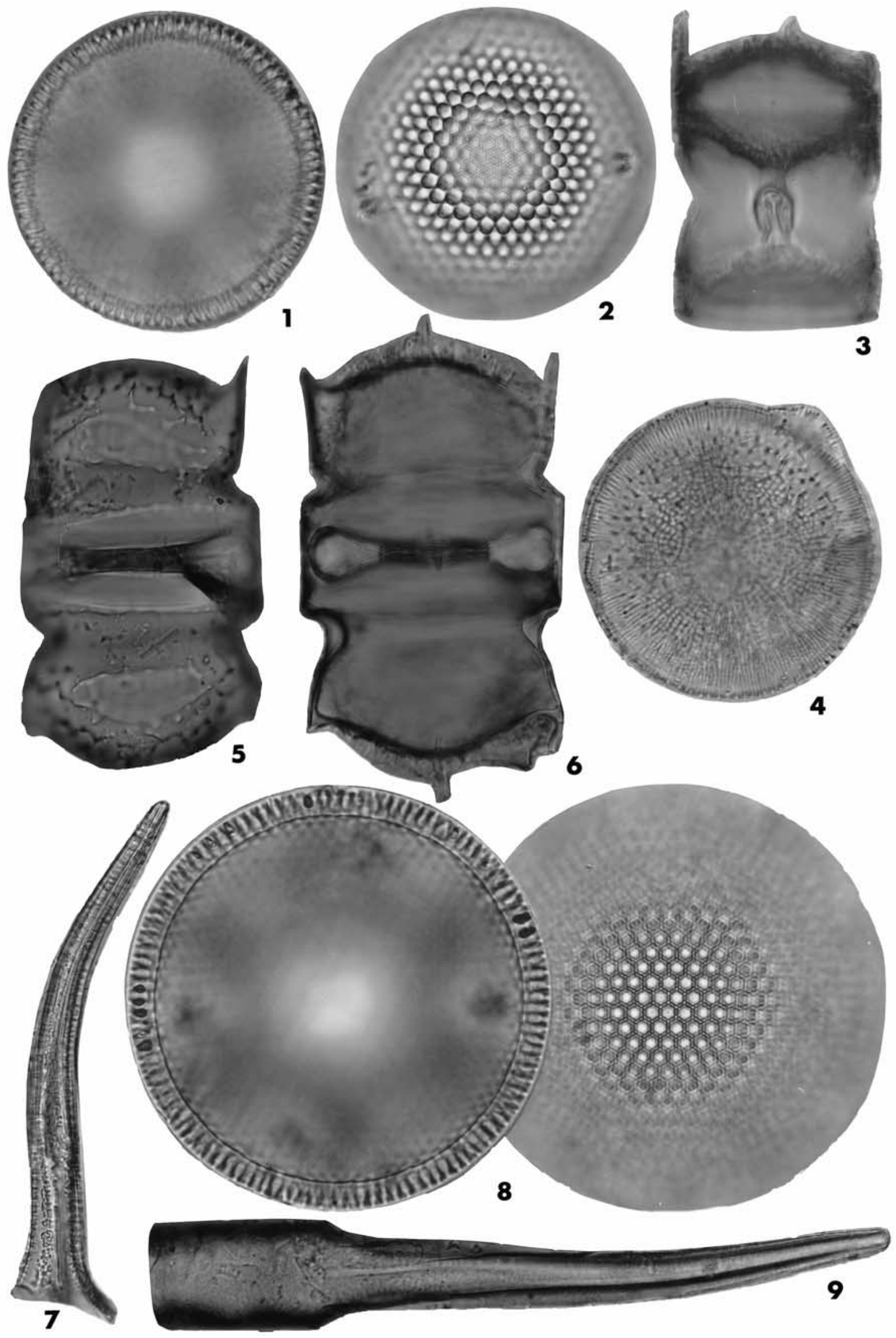
SHIPBOARD SCIENTIFIC PARTY, 1975. Site 275. In: J. P. Kennett and R. E. Houtz, Eds., Initial Reports of the Deep Sea Drilling Project, 29: 19-35.

1989. Site 748. In: R. Schlich, S. W. Wise, Jr., et al., Eds., Proceedings of the Ocean Drilling Program, Initial Reports, 120: 157-233.

SIMS, P. A., 1986. Sphynctolethus Hanna, Ailuretta gen. nov. and evolutionary trends within the Hemiauloideae. Diatom Research, 1(2): 241-269.

1988. The fossil genus Trochosira, its morphology, taxonomy and systematics. Diatom Research, 3(2): 245-257.

1989. Some Cretaceous and Paleogene species of Coscinodiscus: a micromorphological and systematic study. Diatom Research, 4(2): 351-371.

1994a. Benetorus, Gladiopsis and related genera from the Cretaceous. Diatom Research, 9(1): 165-187.

, 1994b. Skeletonemopsis, a new genus based on the fossil species of the genus Skeletonema Grev. Diatom Research, 9(2): $387-410$.

SIMS, P. A. and HASLE, G. R., 1987. Two Cretaceous Stellarima species: S. stenyi and S. distincta; their morphology, palaeogeography and phylogeny. Diatom Research, 2(2): 229-240.

SIMS, P. A. and ROSS, R., 1988. Some Cretaceous and Paleogene Trinacria (diatom) species. Bulletin of the British Museum (Natural History). Botany series, 18(4): 275-322.

STOERMER, E. F. and SMOL, J. P. , Editors, 1999. The Diatoms: Applications for the Environmental and Earth Sciences. Cambridge: Cambridge University Press, 469 pp.

STOTT, D. F., 1969. Ellef Ringnes Island, Canadian Arctic Archipelago. Geological Survey of Canada, Paper 68-16: 1-44.

STRELNIKOVA, N. I., 1964. "New species of diatom algae from the Upper Cretaceous deposits of the Syny River Basin (West Siberia)". Paleophytologii Sbornik, "Nedra", Trudy Vsesoyuznogo Neft, Nauchnois, Geol-razved. Inst. (VNIGRI), 239: 229-232. (In Latin). 1965a. "Diatom algae from the Upper Cretaceous deposits of the Northwestern part of the Siberian depression". Botanicheskii Zhurnal SSSR, 50(7): 986-990. (In Latin).

1965b. De diatomeis cretae superioris raris et novis orientalis montium Uralensium polarium. Novosti Systematiki Nizshikh Rastenii, Botanicheskii Institut, Akademia Nauk SSSR, p. 29-37. (In Latin).

, 1966a. Revisio specierum generum Gladius Schulz et Pyxilla Greville (Bacillariophyta) e sedimentis cretae superioris. Novosti Systematiki Nizshikh Rastenii, Botanicheskii Institut, Akademia Nauk SSSR, p. 23-36. (In Latin).

1966b. Species generis Aulacodiscus Ehr. (Bacillariophyta) novae e sedimentis cretae superioris declivis orientalis partis boralis jugi Uralensis. Novosti Systematiki Nizshikh Rastenii, Botanicheskii Institut, Akademia Nauk SSSR, p. 36-38. (In Latin).

, 1968. "Late Cretaceous diatom algae". Iskopaemge Diatomvye Vodorosli SSSR, Sibirskoe Otdelenie, Inst. Geol. Geof., Akad. Nauk SSSR, p. 17-21. (In Russian).

1971. Species novae bacillariophytorum e sedimentis cretae posterioris in declivitate orientali partis polaris ac praepolaris Montium Uralensium. Novosti Systematiki Nizshikh Rastenii, Botanicheskii Institut, Akademia Nauk SSSR, 8: 41-51. (In Latin).

1974. "Late Cretaceous diatoms of Western Siberia". Akad. Nauk SSSR, Roy, 8: 1-202. (In Russian).

1975. Diatoms of the Cretaceous Period. Third Symposium on Recent and Fossil Diatoms, Kiel. Nova Hedwigia, Beihefte, 53: 311-321.

TAKAHASHI, O., KIMURA, M., ISHII, A. and MAYAMA, S., 1999. Upper Cretaceous diatoms from Central Japan. In: S. Mayama, M. Idei and I. Koizumi (Editors). 14 ${ }^{\text {th }}$ Diatom Symposium, 1996. Koenigstein: Koeltz Scientific Books, pp. 145-155.

TAPIA, P. M., 1996. Campanian diatom biostratigraphy and paleoecology of Arctic Canada. Unpublished Masters Thesis, University of Nebraska - Lincoln, 94 pp.

TAPIA, P. M., 1997. Bioestratigrafía mundial de diatomeas en el Período Cretáceo. Boletín de la Sociedad Geológica del Perú, Volumen Especial, IX Congreso Peruano de Geología, 1: 615-618.

\section{PLATE 9}

1-2 Unidentified resting spore \#3; girdle view, $\times 1875$, low and high focus of the same specimen; Sample C-8629, Horton River.

3-4 Stephanopyxis simonseni Hajós; girdle view, $\times 1250$, low and high focus of the same specimen; Sample C-8618, Horton River.

5-6 Unidentified resting \#4; girdle view, $\times 1875$, low and high focus of the same specimen; Sample C-8627, Horton River.
7-8 Pseudopyxilla sp. cf. P. rossica (Pantocsek) Forti; girdle view, $\times 1250$, high and low focus of the same specimen; Sample C-8629, Horton River.

9-10 Stephanopyxis turris (Greville et Arnott) Ralfs; girdle view, $\times 1250$; 9, low focus; 10 , high focus; Sample C8618, Horton River.

11-12 Corinna sp. 1; valve view, $\times 1875$, high and low focus of the same specimen; Sample C-8621, Horton River.

13 Paralia sulcata (Ehrenberg) Cleve; valve view, $\times 1250$, low and high focus; Sample C-8610, Horton River. 

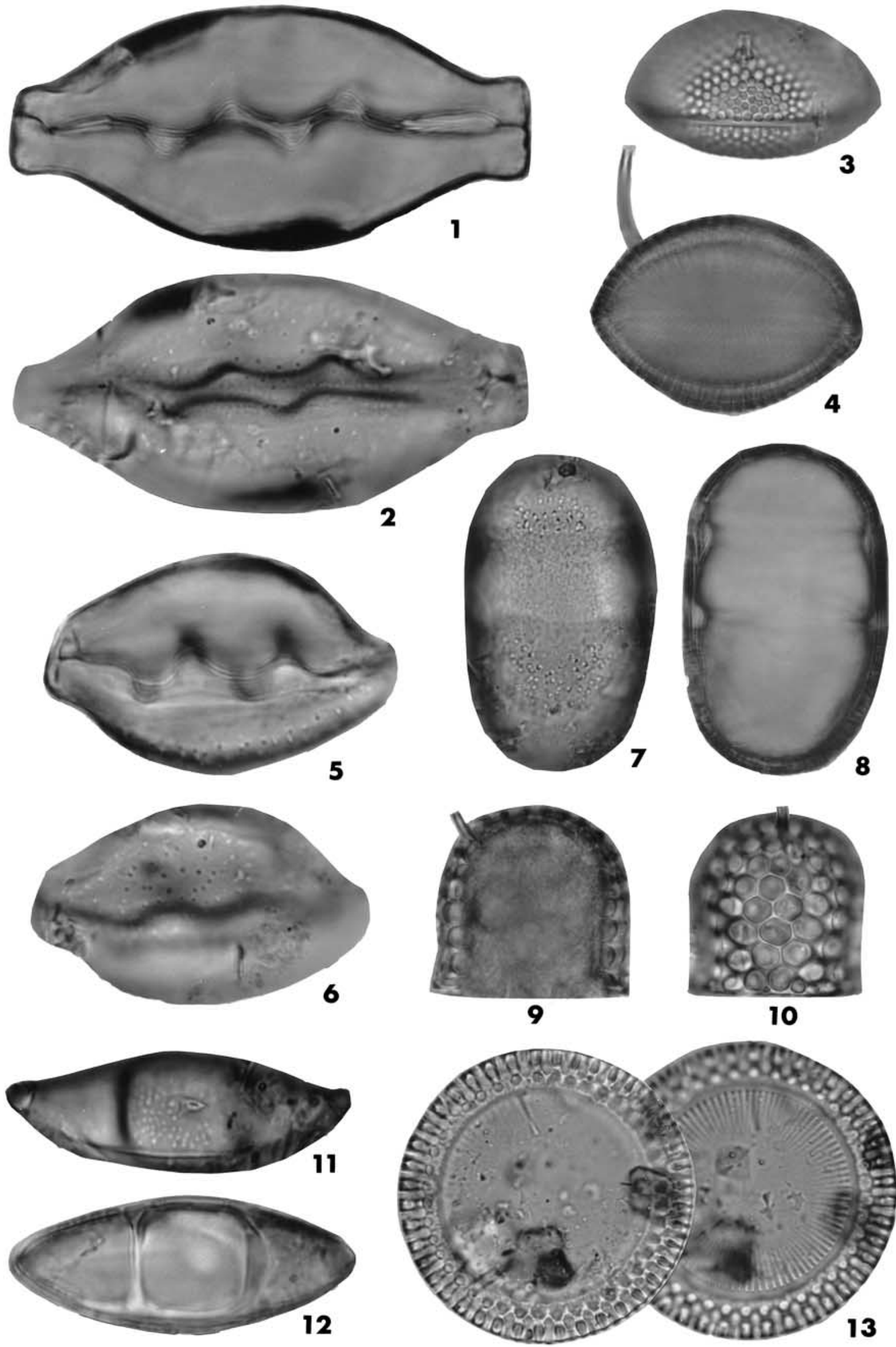
VEKSCHINA, V. N., 1961a. "New genus and new species of the Cretaceous and Paleogene diatoms from the West Siberian depression". Trudy Sibirskogo Naucho-issledovatel'skogo, Inst. Geol. Geof Mineral'nogo Syr'ja, 15: 89-93. (In Russian).

1961b. "The scheme of subdivision of the Cretaceous and Paleogene deposits of the West Siberian Depression based on the analysis of algae diatoms, silicoflagellates, ebridaceae, and coccolithophorids". In: Decissions and Proceedings of the Intraregional meeting on working out a stratigraphic scheme for the West Siberian depression. Gostoptekhizdat, Leningrad, pp. 223-237. (In Russian).

VINCENT, J. S., OCCHIETTI, S., RUTTER, N., LORTIE, G., GUILBAULT, J. P. and DE BOUTRAY, B., 1983. The late TertiaryQuaternary stratigraphic record of the Duck Hawk Bluff, Banks Island, Canadian Arctic Archipelago. Canadian Journal of Earth Science, 20(11): 1694-1712.

WALL, J. H., 1975. Diatoms and radiolarian from the Cretaceous System of Alberta, a preliminary report. In: W. G. E. Cadell, Ed., The Cretaceous System in the Western Interior of North America. Geological Association of Canada, Special Paper, 13: 391-340.

1983. Jurassic and Cretaceous foraminiferal biostratigraphy in the eastern Sverdrup Basin, Canadian Arctic Archipelago. Canadian Petroleum Geology, Bulletin, 31(4): 246-281.
WATKINS, D. K., QUILTY, P. G., MOHR, B. A. R., MAO, S., FRANCIS, J. E., GEE, C. T. and COFFIN, M. F., 1992. Paleontology of the Cretaceous of the Central Kerguelen Plateau. In: S. W. Wise, Jr., R. Schlich, et al., Eds., Proceeding of the Ocean Drilling Program, Scientific Results, 120(2): 951-960.

WIEDMANN, M., 1964. Présence de diatomées dans le Flysch à Helminthoïdes. Bulletin des Laboratoires de Géologie, Minéralogie, Géophysique et du Musée géologique de l'Université de Lausanne, (145): 1-5.

WEISNER, H., 1936. Sur la découverte de diatomés et autres microfossiles peu connus dans le Crétacé superieur de la Bohême. Annales de Protistologie, 5: 151-155, Pl. VI-VII.

WITT, O. N., 1886. Ueber den Polierschierfer von ArchangelskKurojedowo im Gouv. Simbrisk. Verhandlungen der Russischkaiserlichen mineralogischen Gessellschaft zu St. Petersburg, Series II, 22: 137-177, Pl. 6-12.

YORATH, C. J., BALWILL, H. R. and KLASSEN, R. W., 1969. Geology of the eastern part of the Northern Interior and Arctic Coastal Plains, Northwest Territories. Geological Survey of Canada, Paper 68-27: 1-29.

1975. Franklin Bay and Malloch Hill map-areas, District of Mackenzie (95 C, F). Geological Survey of Canada, Paper 74-36: $1-35$.

Manuscript received April 15, 2002

Manuscript accepted September 11, 2002 